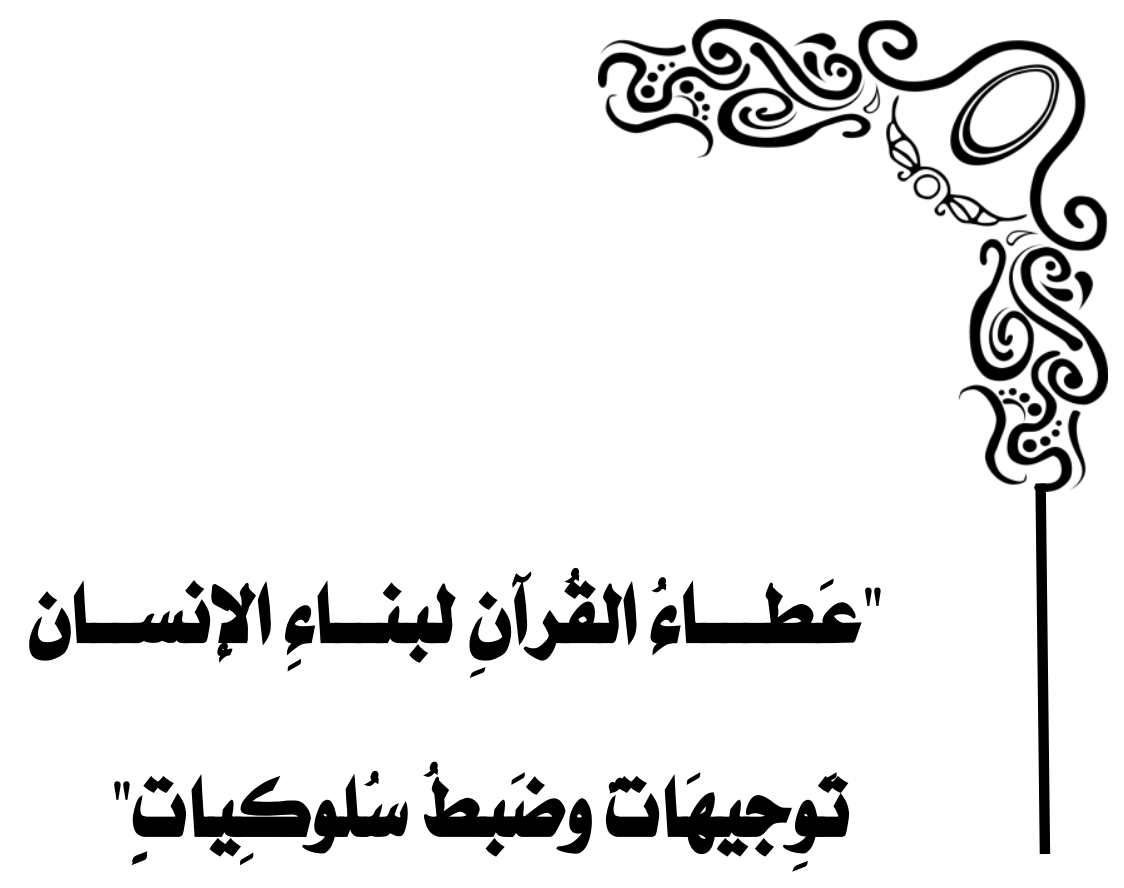

$$
\begin{aligned}
& \text { إعداد اللدكثور: } \\
& \text { احمهـل حسيز مهلي الأكـرث } \\
& \text { مـلدرس التفسـيـي وملـوم القـــــرآن } \\
& \text { بكلية الدراسات الإسلامية والعريية } \\
& \text { لبنين بالقاهرة } \\
& \text { (1) }
\end{aligned}
$$




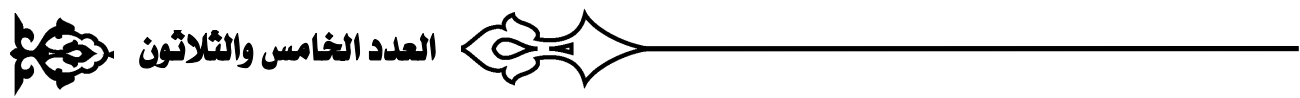




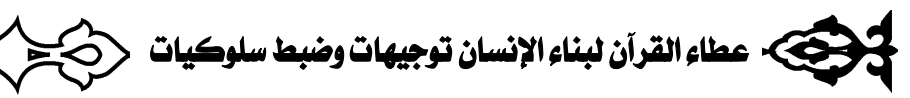
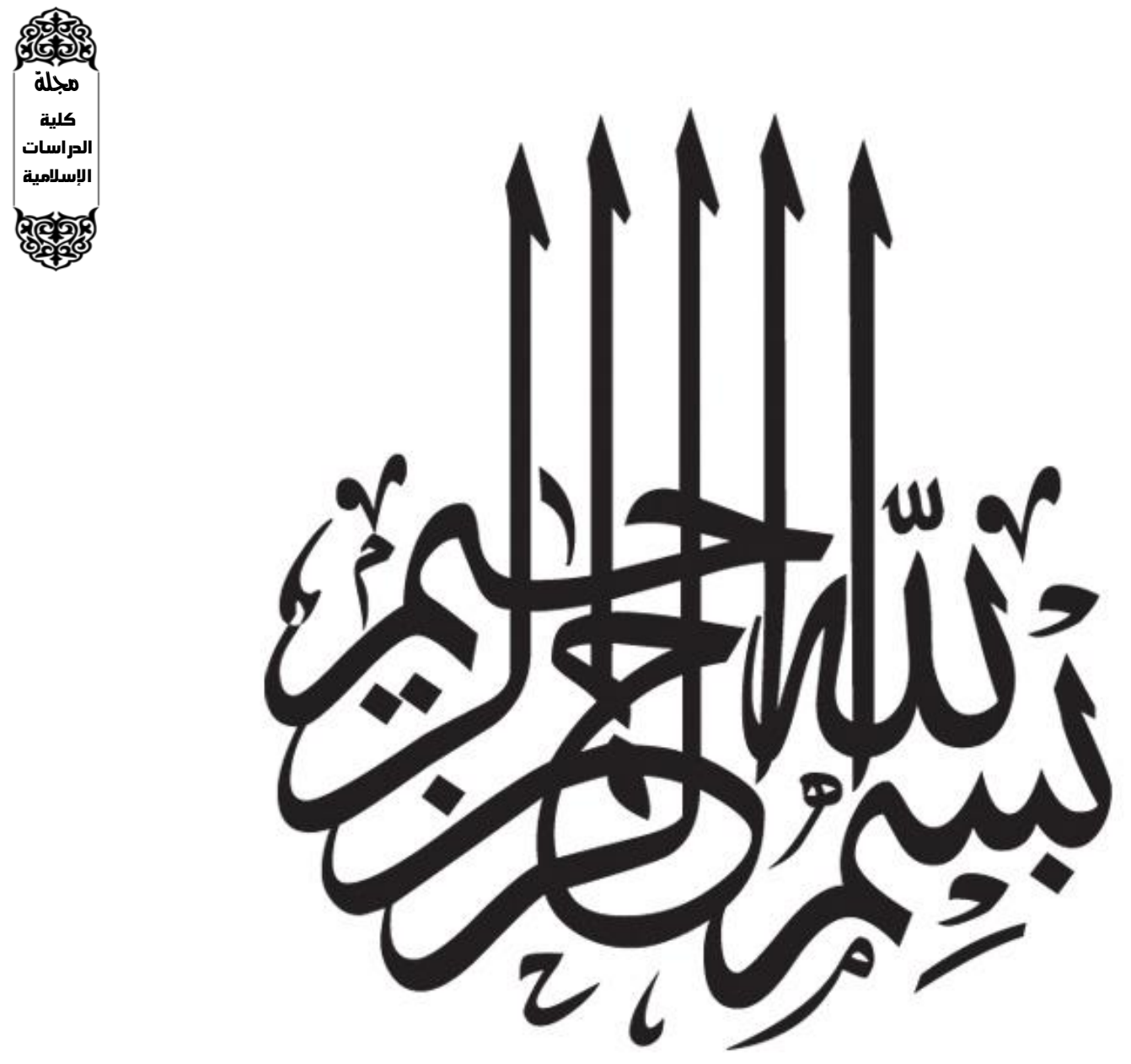


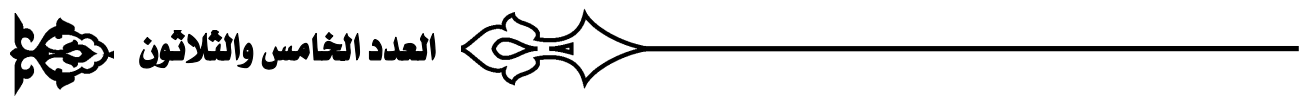


3.

\section{ملخــــ البحث}

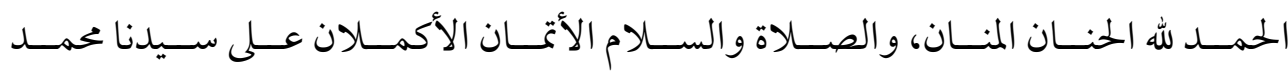

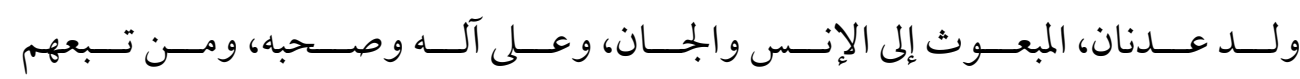
بإحسان، وبعد،

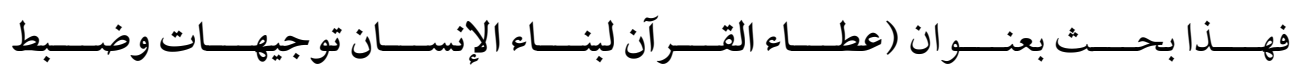

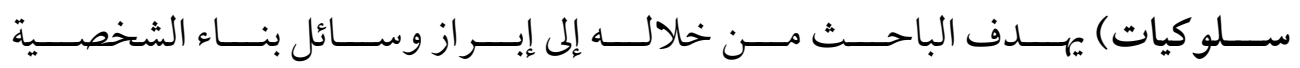

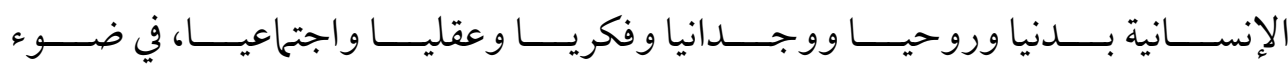

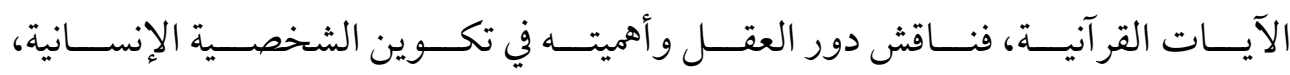

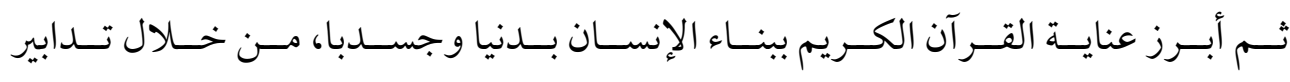

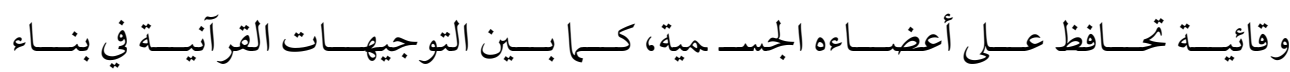

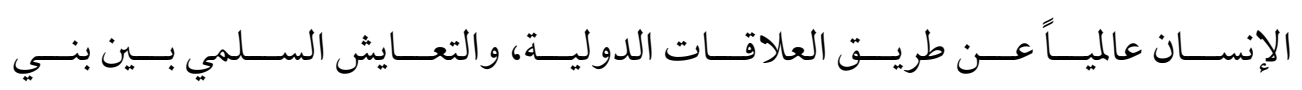
الإنسان في ضوء الشريعة الإسلامية. 


\section{العدد الثامس والثُلاثون .}

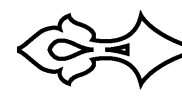

\section{Gifts of the Qur'an to build up the Human Being "Guidelines and Disciplines"}

\section{By: Dr. Ahmed Hussein Mahdy Al-Akrat}

Lecturer in Hermeneutics and Qur'an

Faculty of Islamic and Arabic Studies (Males Branch) in Cairo

\section{Abstract}

This research, entitled (Gifts of the Qur'an to build up the Human Being "Guidelines and Disciplines), aims at examining the physical, spiritual, intellectual, mental and social aspects of building the human being in the light of the Qur'anic verses. In addition, the research discusses the role of the mind and its importance in forming the being. Then, it demonstrates the Qur'anic care to build up the human being physically and spiritually through setting protective measures that keep his precious organs. Finally, the research has handled the Qur'anic guidelines followed to build up the human being universally through international relations and peaceful co-existence in between all mankind in accordance with the Muslim jurisprudence.

Key words: Gifts of the Qur'an, building up the human being, coexistence

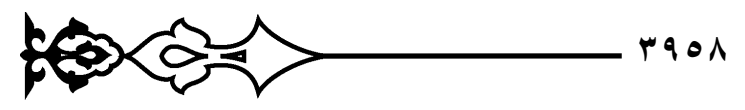




\section{3}

\section{المقدمسـام}

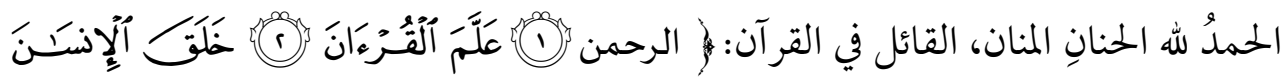

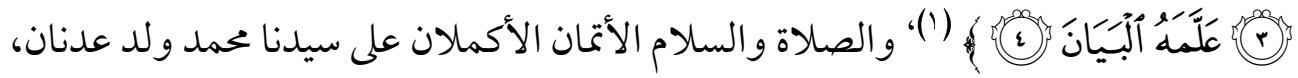
المبعوث إلى الإنس والجان، وعلى آله وصحبه، ومن تبعهم بإحسان .

\section{وبعســ}

فالقر آنُ الكريم كتابُ هدايةٍ، ومنهجُ حياةٍ، فيه بيانٌ مشرق لكلّ ما يحتاجه النّاس، ويكفل لهم

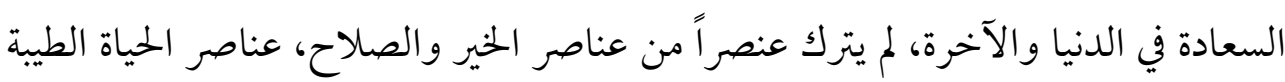
والسعادة الخالدة إلا أمر به، ودعا إليه، وحثّ عليه، ولم يترك عنصراً من عناصر الشّر

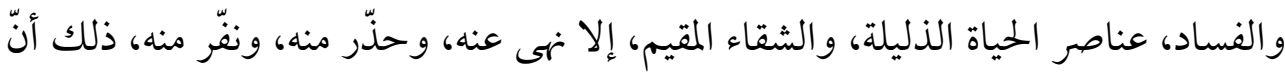

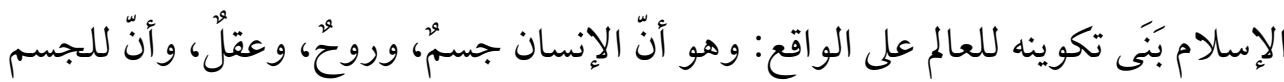

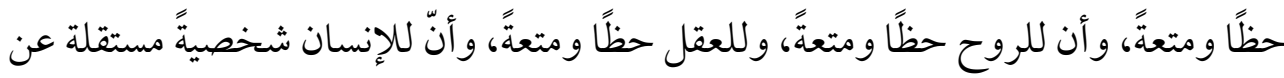

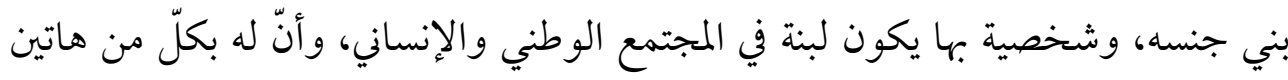

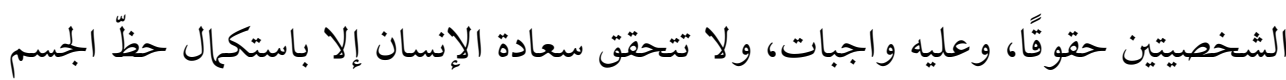
و الروح والعقل، وتنظيم حقوقه، وواجباته في نفسه، وفي مجتمعه، دون إفراط ولا تفريط . وكلّ ما جاء في الإسلام من عقائد، وعبادات، وآداب، وتشريعات، لا يخرج عن هذه الدائرة: دائرة حظّ الجسم، والروح، والعقل للإنسان في شخصه، وفي مجتمعه. فالإنسانُ إذن هو: قضية القضايا في الدين، وهو محور هذا الكون، وهو سيّدُّ في هذا الكون، والذي أعطى له هذه المكانة الفريدة هو: الله - سبحانه -، الذي جعله خليفةً في الأرض،

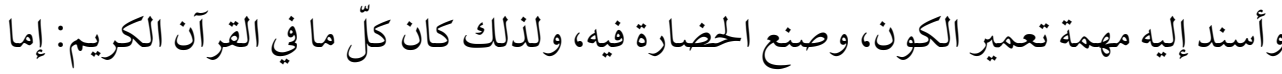

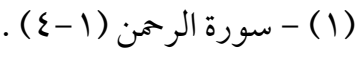




\section{0}

العدد الخامس والثلاثون

حديثًا عن الإنسان، أو حديثًا إلى الإنسان، وأنّ الموضوع الأساس الذي يركز عليه القرآن

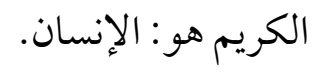

واستمساك الإنسان بالمبادئ الإلهية التي بيّنها الله في كتابه، وختم بها الرسالات السماوية،

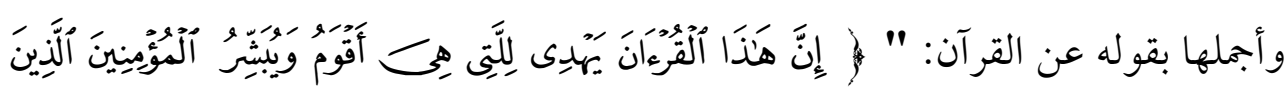

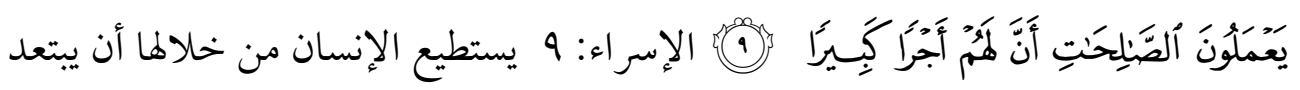

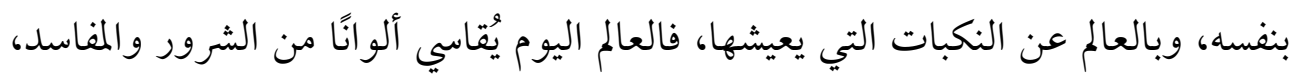

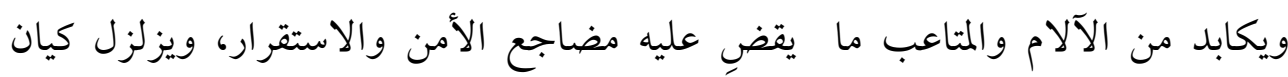

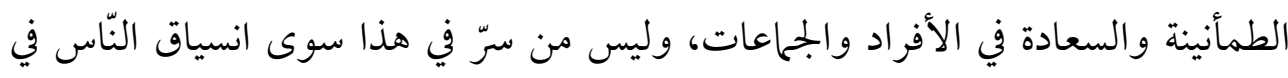

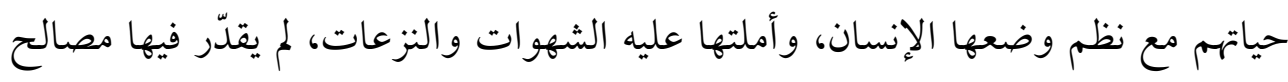

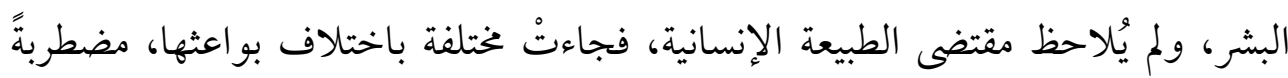

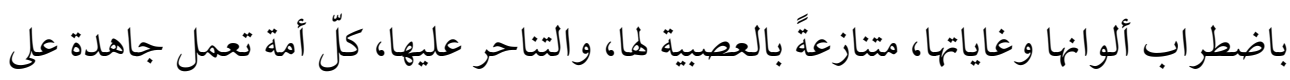

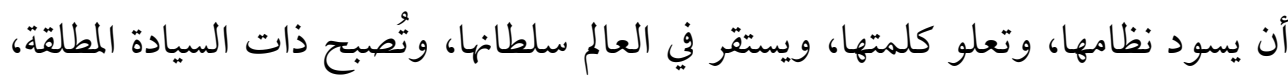

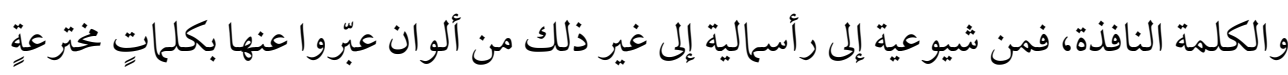

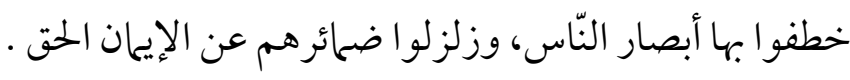
وقد جاءتْ هذه اللبنة كنوع لكيفية بناء الإنسان كما يصوره القرآن الكريم، وهي مشتملة على

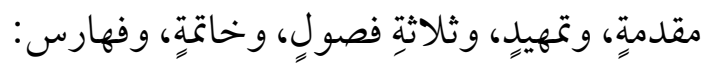
أما المقدمة: فبعد الثناء على اله - تعالى - فيها، و الصلاة والسلام على رسوله محمد صلى الله عليه وسلم تناولتْ الحديث عن أهمية الموضوع، ومكانته.

وأما التمهيد: ففيه الحديث عن مفردات الموضوع من حيث: العطاء - البناء - الإنسان -

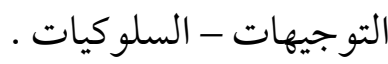

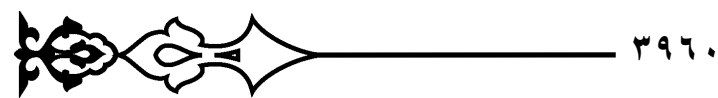


الفصل الأول: بناء الشخصية الإنسانية في ضوء الآيات القر آنية، وفيه ثلاثة مباحث: البجحث الأول: بناء الإنسان روحيا ووجدانيا، وفيه ثلاثة مطالب:

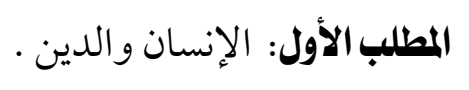

$$
\text { المطلب الثاني: الضمير الإنساني . }
$$

المطلب الثالث: آفات البناء الروحي وكيفية علاجها في ضوء القرآن الكريم .

البحث الثاني: بناء الإنسان فكريا وعقليا، وفيه ثلاثة مطالب:

$$
\text { المطلب الأول: العقل ومقاصد الشريعة الإسلامية. }
$$

المطلب الثاني: الوظيفة التربوية للعقل.

المطلب الثالث: مبطلات التفكير السليم.

المبحث الثالث: بناء الإنسان جسداً ومادياً، وفيه مطلبان:

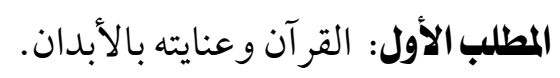

الططلب الثاني: التدابير الوقائية في المحافظة على أعضاء الإنسان الجسمية.

الفصل الثاني: البناء المجتمعي في المنهج القرآني، وفيه ثلاثة مباحث:

$$
\text { البجحث الأول: الحديث القرآني عن الأسرة. }
$$

المبحث الثاني: التضامن الاجتماعي في البيان القرآني.

المبحث الثالث: المو اطنة والعمل المشترك.

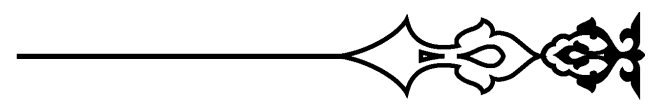




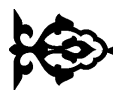

العدد الخامس والثلاثون

الفصل الثالث: التوجيهات القرآية في بناء الإنسان عالمياً عن طريق العلاقات الدولية، وفيه مبحثان:

المبحث الأول: القرآن الكريم وترسيخ القيم الحضارية.

المبحث الثاني: القرآن الكريم وتوثيق العلاقات الدولية والتعايش السلمي، وفيه مطلبان: المطلب الأول: قو اعد العلاقات الدولية في الشريعة الإسلامية.

المطلب الثاني: القرآن و التعايش السلمي بين بني الإنسان .

الخاتمة.

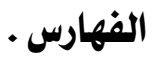




\section{التمهيد: - 20 - التيد}

\section{وفيه تعريف بمفردات البحث، ومعاني كلماته، والمراد من هذا العنوان:}

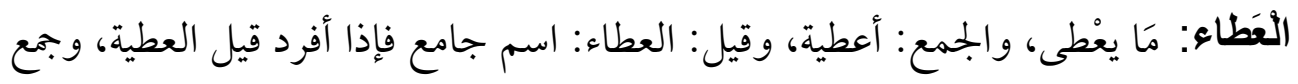

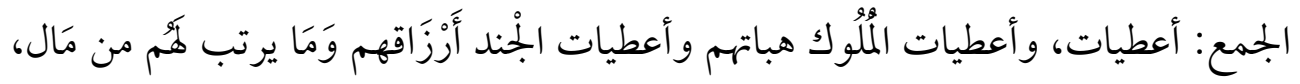
و الْعَطِيَّة: الْعَطاء ( ج ) عطايا، والعطاء: للغني و الفقير، والتصدق : يختص بالفقر اء . (1)

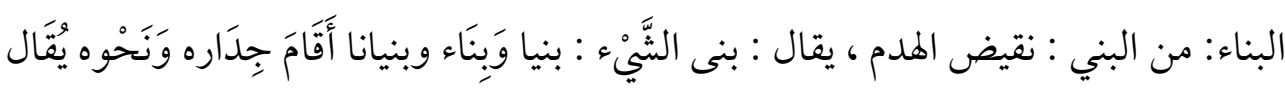

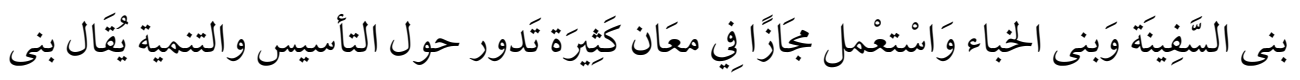

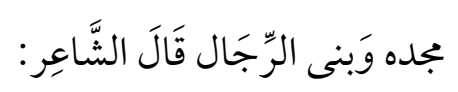

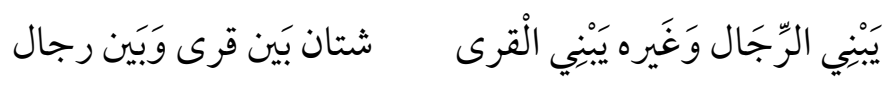

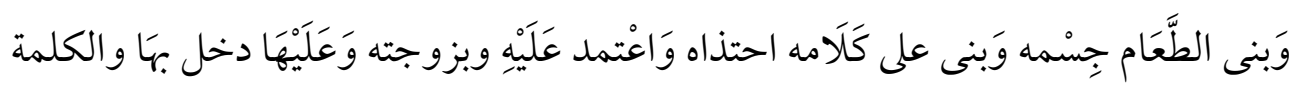

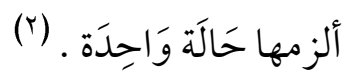

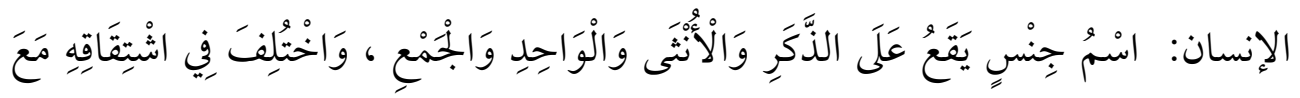

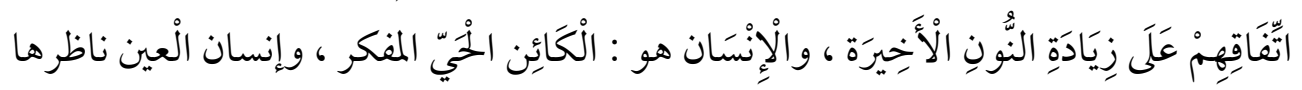

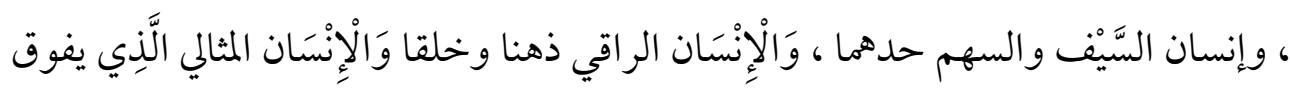
العادي بقوى يكتسبها بالتطور ، (ج) أناسي (أَصله أناسين ) . (r)

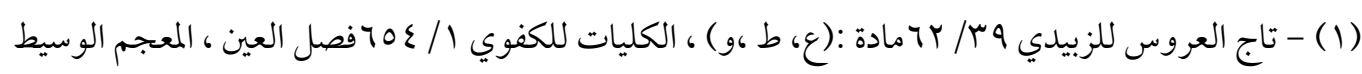
لمجمع اللغة العربية / / ه • باباب العين

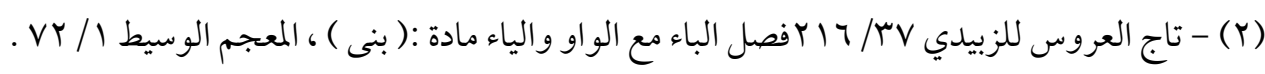

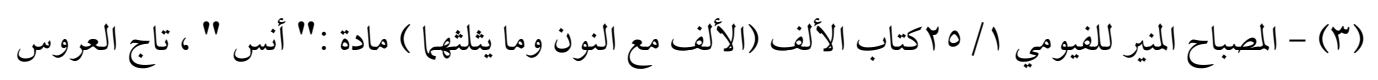

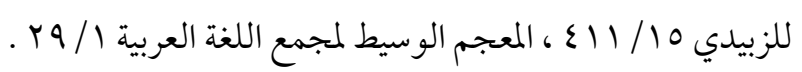




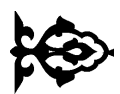

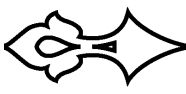

توجيهات: جمعُ، مفردها: توجيه (لغير المصدر)؛ إذ مصدرها: وجَّهَ، يُقال: (تَوَجَّهَ) نَحْوَهُ

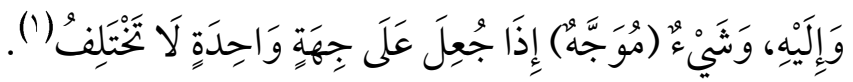

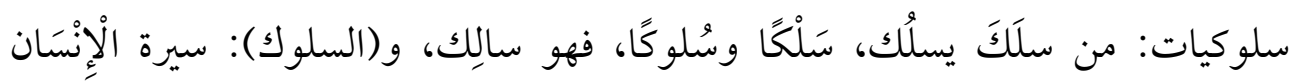
ومذهبه واتجاهه، يُقَال: فلَان حسن السلوكَ أَو سيء السلوك. (؟) والمراد به هنا: ما أورده القرآن الكريم وذكره من فتوحات وأعطيات ونفحات في مراعاة القيم والمبادئ الأخلاقية والإنسانية المستمدة من الشرع الحنيف، وترجمة هذه القيم والمبادئ إلى برامج عمل؛ ليتمكن الإنسان الذي له قلب وألقى السمع وهو شهيد فاستفاد من هذا الخير الموجود في القرآن الكريم كما يستفيد الإنسان مما يقدم إليه من عطاء في الجوانب المادية، ويقوم بتطبيقها حتى ينضبط السلوك الإنساني .

$$
\text { (Y) - (1) - مختار الصحاح صـ عبس مادة ( و ج هـ) }
$$




\section{3}

ع عطاء القرآن لبناء الإنسان توجيهات وضبط سلوكيات

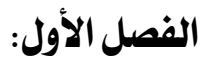

\section{بناي الشخصية الإنسانية في ضوئ الآيات القرآنية:}

الشخصية لفظة تستعمل - عند علماء الاجتماع - غالبا للتعبير عن مكونات فرد ما ، وما يمكن أن نتعرف عليها من خلال صفاته البارزة ، أو تصرفاته التي نشاهدها أو سلوكه الخلقي أو علاقته بالآخرين أو أسلوبه في التفكير وطريقة الفهم ، ولم يستخدم القرآن الكريم تلك اللفظة بأي معنى من المعاني التي ذهب إليها النفسيون ، وإنها استخدم بعض مشتقات

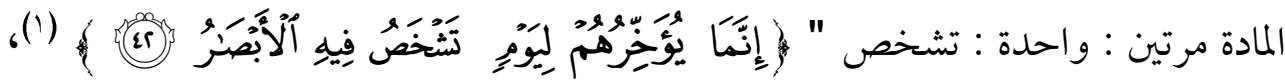

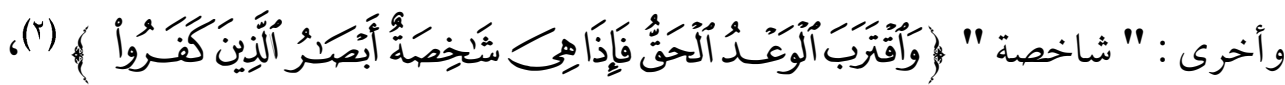
وأقرب الألفاظ التي استخدمت في النص الإسلامي قريبا من دلالة الشخصية عند علماء النفس هي لفظة الإنسان والناس ، أما في اللغة العربية فإن المتأمل في كلمة ( الشخص ) يجد أنها تدور مع ما سبق تعريفه . (r) ويعتبر بناء الإنسان بناءً متكاملًا جسديَّا وروحيَّا وفكريًّا ونفسيَّا وأخلاقيَّا من أولى اهتمامات منهج الإسلام - بل يعدّ مركز هذا الاهتحام ويؤرته -، ويرجع هذا الاهتحام إلى علو منزلة الإنسان بين سائر المخلوقات، ولعظم دوره المستخلف فيه من الله؛ لبناء العمران الماديّ والمعنويّ لمجتمعه، ولم يكن بناء الإنسان بالأمر الهين اليسير، فمهمة بنائه كانت وما تزال الأصعب والأهم من بناء المصانع، وذلك راجع إلى أنّ الإنسان المطلوب هو الذي تتوازن

$$
\text { (Y) - سورة إبراهيم من الآية (Y) - (Y) - سورة الأنبياء من الآية (YV). }
$$

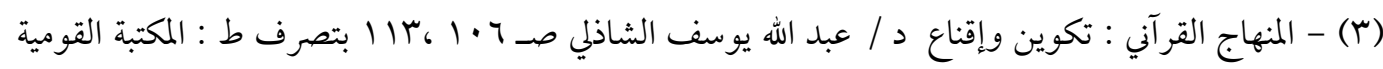
الحديثة بطنطا . 


\section{5}

أشو اقه الروحية ونزعته العقلية وعو اطفه وغرائزه مع اهتماماته وتوجيهاته الدنيوية وأشواقه الروحية بحيث تتصالح هذه التوجيهات والاهتمامات ولا تتصادم أو تتحارب. هذا الإنسان هو المطلوب اليو وغداً حتى يؤدي مهمة استخلافه على الوجه الذي يراد له . والإنسان محور المنهج الإلهي، وله غاية من خلقه يريد خالقه أن يبلغها من خلال الالتزام

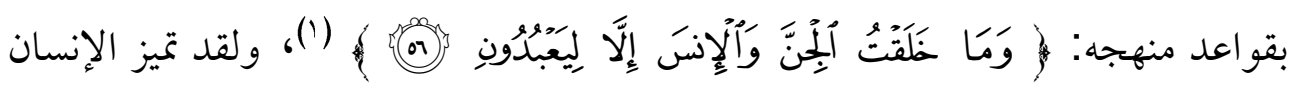
باستعدادات وقدرات يمكن تنميتها من اتباع قواعد المنهج الإلهي ثم الارتقاء بالإنسان ارتقاءُ متكاملًا في إطار هذه القو اعد.

ولذلك جاء الحديث عن خصائص الطبيعة الإنسانية من خلال المباحث الآتية :

\section{المبحث الأول : بنائ الإنسان روحيا ووجدانيا :}

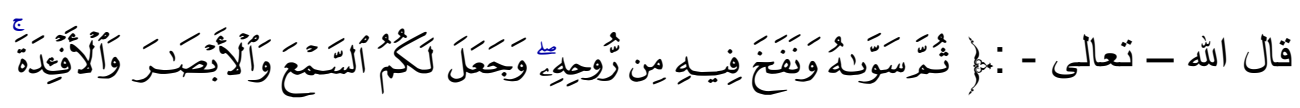

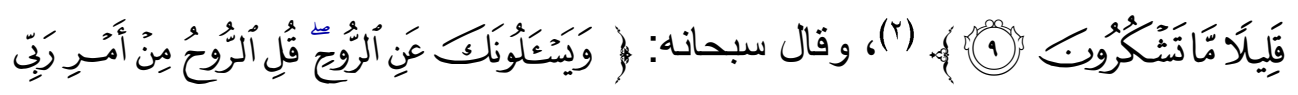

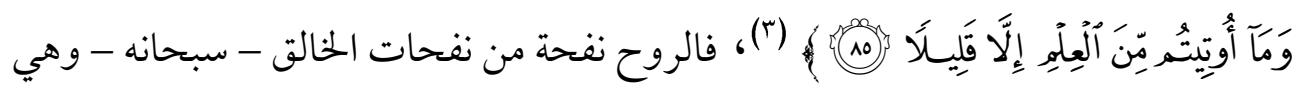
سرّ من أسراره أودعها الله - تعالى - هذا الجسدِ المادي فوهبته الحياة حتى يستطيع أن يؤدي مهمته ووظيفته ، ويكون مدركا لظروف عصره ومتطلباته بحيث يتفاعل مع البيئة وأن ينفعل بها ، وأن يؤثر فيها ويتأثر بها ، ويظهر ذلك من خلال هذه المطالب :

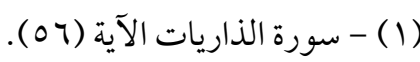

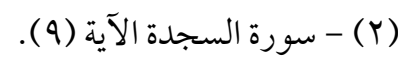

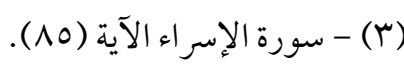




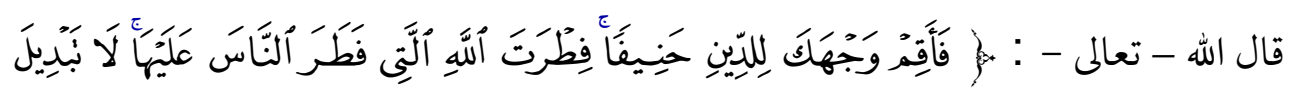

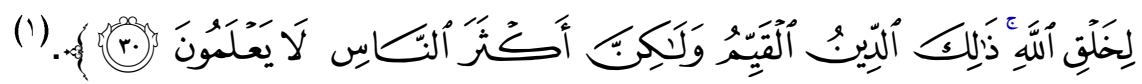

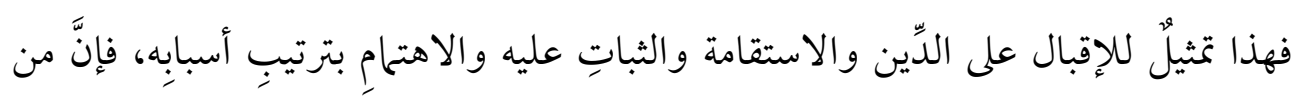

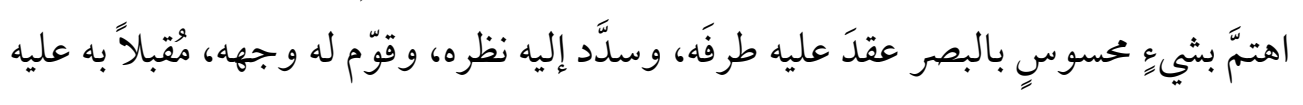

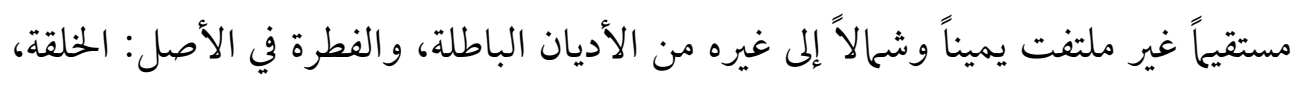

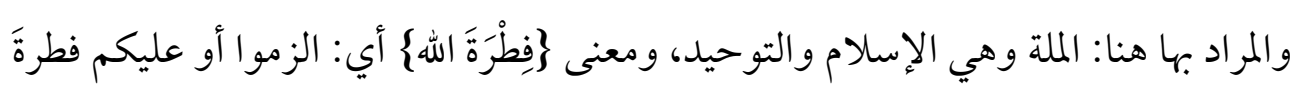

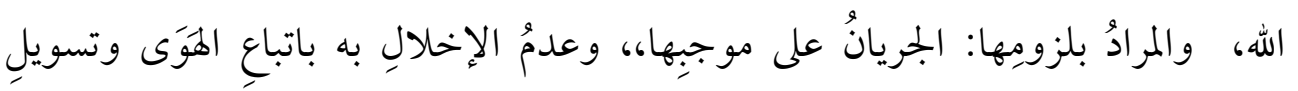

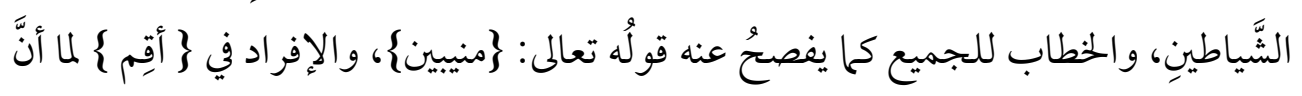

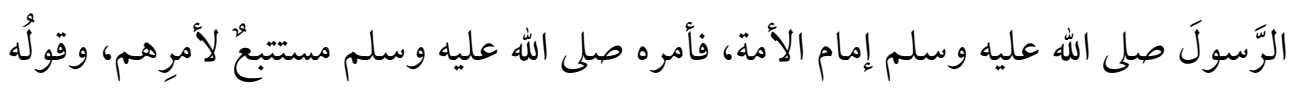

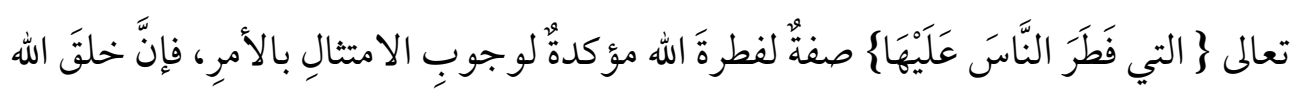

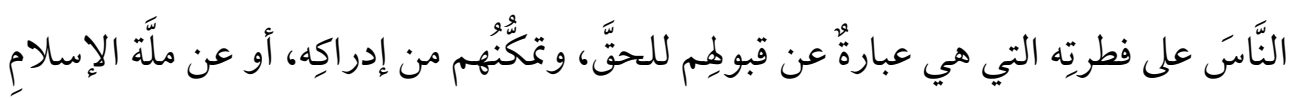

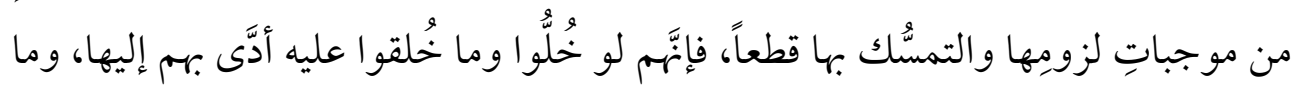

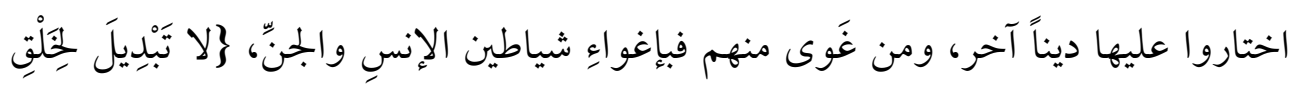

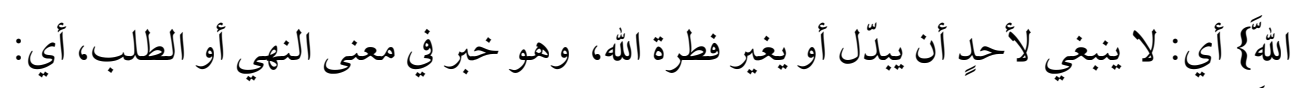

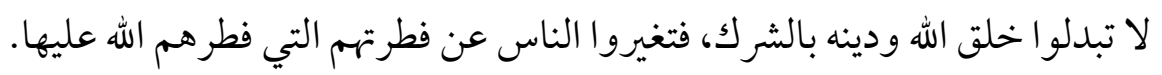

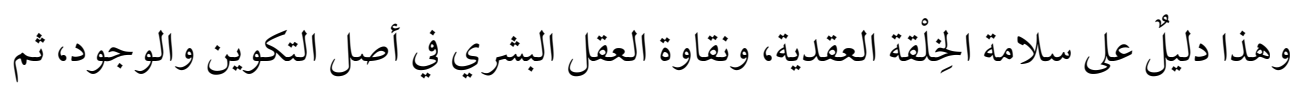

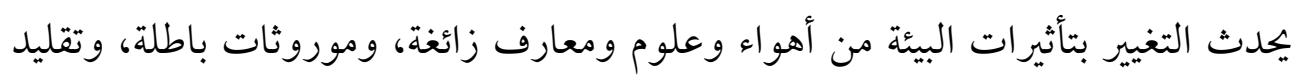

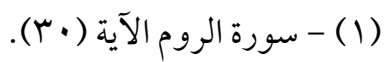




\section{5}

مستمر للأسلاف، دون إعمال الفكر، وتكوين الاعتقاد بالنظرة المستقلة الصائبة، ولو ترك

الإنسان وشأنه لما اختار غير الإسلام دينا؛ لأنّه دين الفطرة والعقل. (')

فـ [ الدين فطرة أصيلة في نفس الإنسان فطره الله عليها، فهو أحد المكوّنات الرئيسة لكل الحضارات التي صنعها الإنسان على مدى تاريخ البشرية ، وليست هناك أمة عاشت ثم مضت دون أن يكون لها تصور بشكل من الأشكال عن الدين والألوهية والمصير ، و إذا كان الدين يلبي حاجات الإنسان الروحية فإن ذلك يعني أنه قد جاء لمصلحة الإنسان ، وإذا تأملنا تشريعات الإسلام كلها بها فيها العبادات نجد أنها جميعاً تنطلق من منطلق واحد هو مصلحة الإنسان وسعادته في الدنيا والآخرة.

إن الإسلام هو نفس تلك الفطرة ، فالإسلام ليس بتقاليد وموروثات وآراء وشروح ، ولكنه تلك الفطرة مجردة من كل شائة ، وهي تئدي بالإنسان - بقواها الذاتية - إلى أقوم طريق ، وأعدل المذاهب ، وقد قال النبي صلى الله عليه وسلم : " كل مولود يولد على الفطرة " (؟) أي : أن كل مولود يولد مفطوراً على الدين الخالص الذي هو الدين الحق وحده وهذا يعني

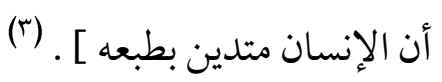

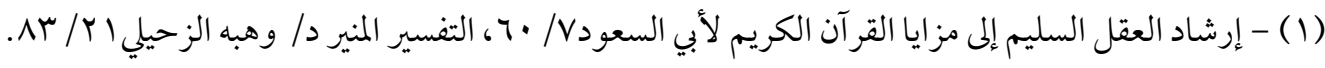

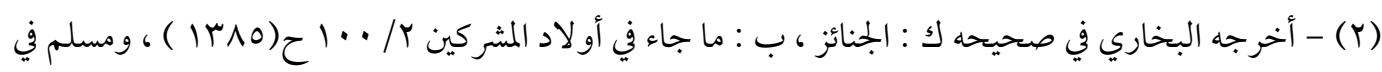

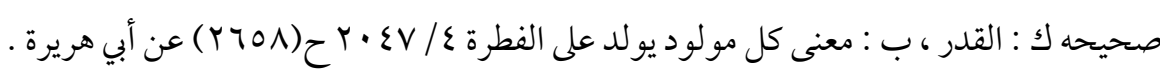

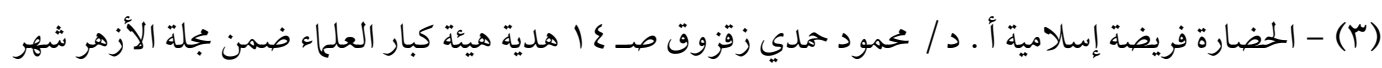

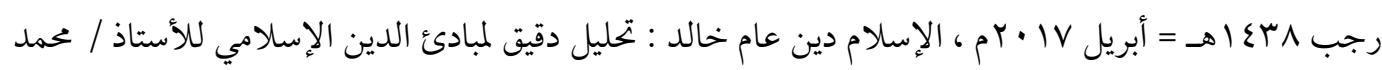

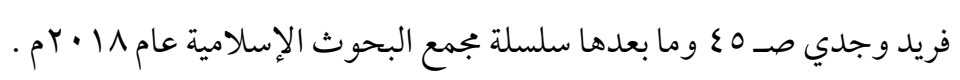

क्षेति 


\section{3}

فالإسلام عقيدةٌ تقوم على الفهم و الإقناع ، ومعرفة الله - تعالى - تُنبى على التأمل و التفكر،

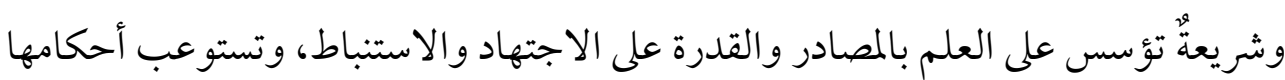
شئون الحياة وجو انبها وعلاقاتها المتعددة، وهو دينّ يهتم بالسلوك الإنساني، وتحليل بواعث الأفعال وعلل الصفات النفسية وعلاجها، ويتناول النفس الإنسانية في فطرتها ودوافعها الخيرة والشريرة والفاضلة والمذمومة، ويتحدث عن كلّ ذلك باستفاضة مرغبًا في الخير محذرًا كلّ التحذير من مسالك الشر وعواقبه الوخيمة، ويبيّن لتلك النفس نشاطها المطلوب والمحمود في الدنيا، والذي إن قامت به حققت السعادة في الدنيا والآخرة وإلا تعستْ في

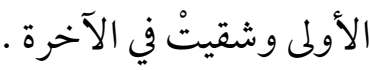
وكون الإنسان خليفة الله في الأرض تقتضيه تلك الخلافة أن يفهم طبيعتها من الإسلام، ومهامها من أحكامه، وأن يعي بعلمٍ مستنيرٍ هذا الكون ومظاهره وقو انينه، وأن يستثمر هذا الوعي لمنفعته الدنيوية، وفي علاقته بربه عن طريق العلم بحكمته وإبداعه و أسراره العميقة في هذا الكون ، ويكون بذلك جديراً بمنصب الخلافة ما دام يتبع قانون السير والنظر في هذا الكون استخلفه الله عليه .

[ وقد اهتم القرآن ببناء الدين ويظهر ذلك من خلال دعوة القرآن إلى حرية العقيدة: فلم يلبث الإسلام أن استقر وتبينت للناس تعاليمه حتى قرّر بهذا الصدد ثلاثة مبادئ هي أرقى ما وصل إليه التشريع الحديث بصدد حرية الأديان والمعتقدات: أحدها: أنّه لا يرغم أحدًا على ترك دينه واعتناق دينٍ آخر ولو كان الإسلام، وفي هذا يقول

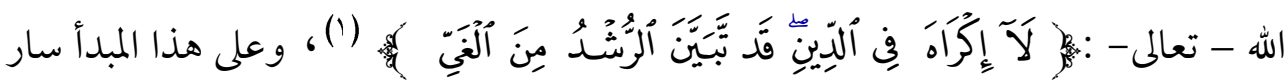
المسلمون في حروبهم مع أهل الأديان الأخرى، فهذا عمر بن الخطاب - رضي الله عنه -

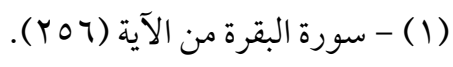




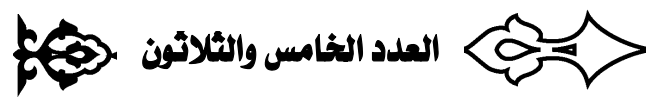

يقول في كتابه لأهل بيت المقدس عقب فتحه له: " هذا ما أعطى عمرُ أمير المؤمنين أهلَ إيلياء

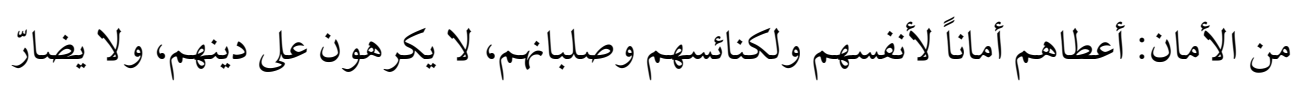

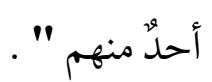

المبدأ الثاني الذي سنّه الإسلام بهذا الصدد هو: حرية المناقشات الدينية، ولذلك ينصح الله

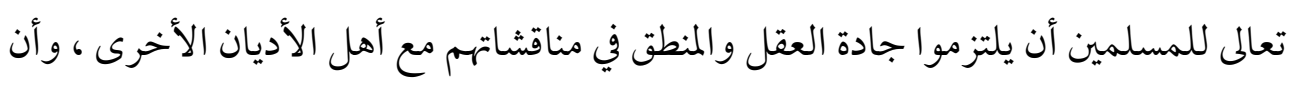

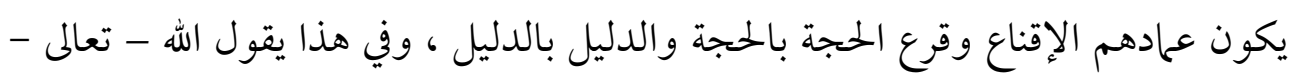

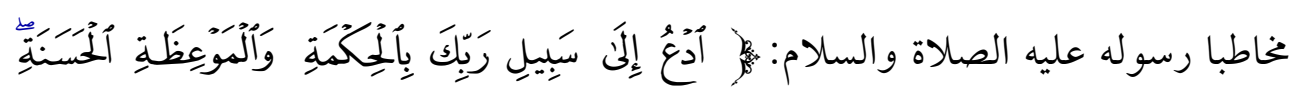

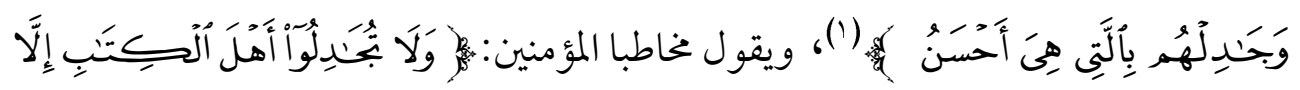

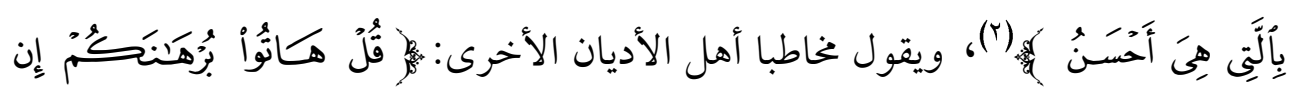

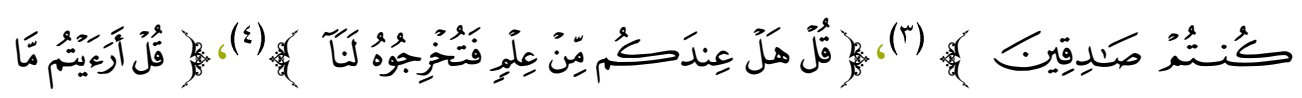

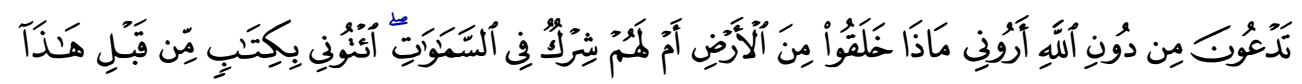

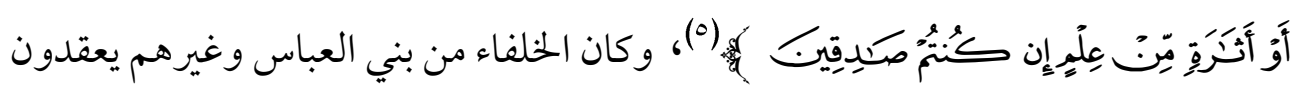

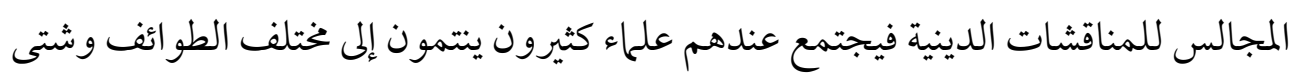

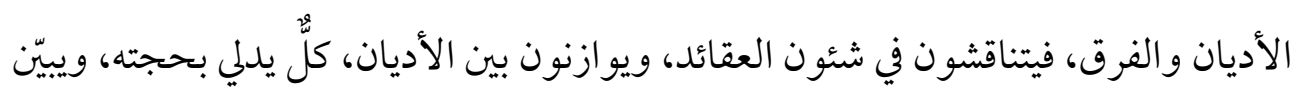

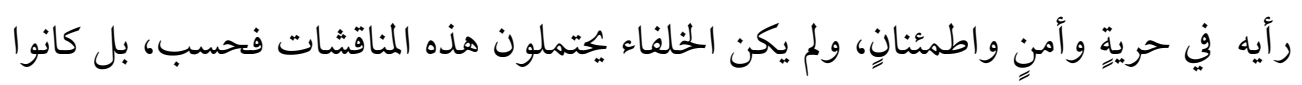

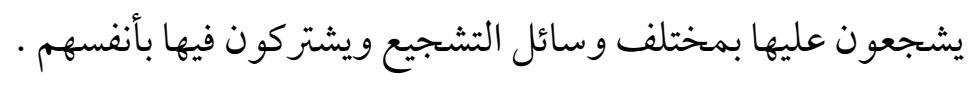

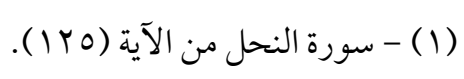

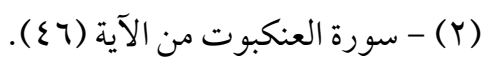

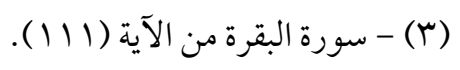

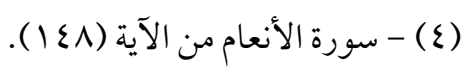

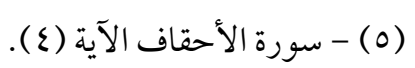




\section{3}

والمبدأ الثالث الذي وضعه الإسلام بهذا الصدد هو: أن الإيهان الصحيح هو ما كان منبعثا عن يقين واقتناع لا عن تقليد واتباع ، وبذلك حطم الإسلام القواعد التي قام عليها التدين في كثير من الأمم من قبله، وهي قواعد التقليد والاتباع وإهمال النظر والتفكر الحر، وأهاب بالنّاس أن يجعلو اعمادهم في عقائدهم ونشر دينهم الدليل العقلي والمنطق السليم ، وحثّ على رفض ما لا يؤيده علم ، ولا يعززه دليل ، ولقد أخذ الله على المشركين التقليد الأعمى لآبائهم

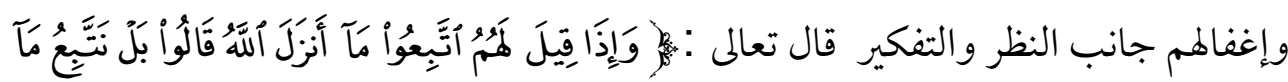

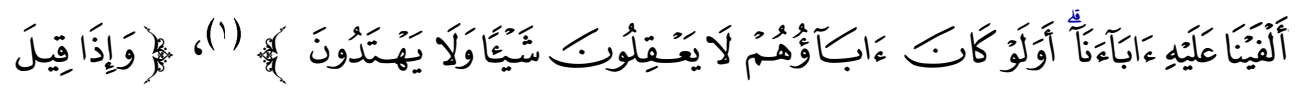

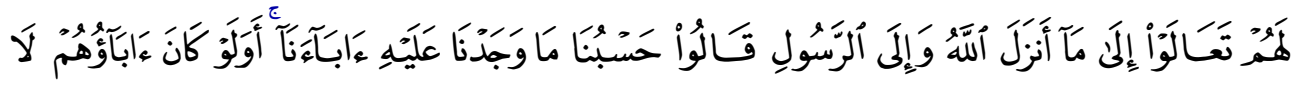

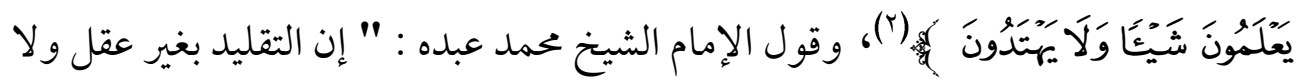
هداية هو شأن الكافرين، وإن المرء لا يكون مؤمناً إلا إذا عقل دينه وعرفه بنفسه حتى اقتنع به ، فليس القصد من الإيهان أن يذلل الإنسان للخير كما يذل الحيو ان ، بل القصد أن يرتقي عقله وترتقي نفسه بالعلم فيعمل الخير ؛لأنه يفقه أنه الخير النافع المرضي لله ،ويترك الشر ؛ لأنه يفهم سوء عاقبته ودرجة مضرته " ]

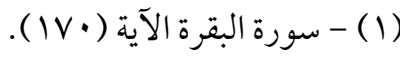

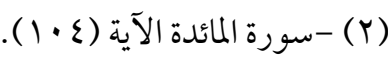
(r) - حقوق الإنسان في الإسلام للدكتور / علي عبد الواحد وافي صـ V• اوما بعدها ط ( (r) المجلس الأعلى

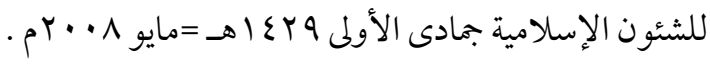




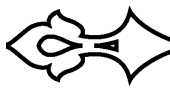

المطلب الثاني : الضمير الإنساني :

إنّ الضمير يملك على الإنسان باطنه وظاهره وخلوته قبل جلوته، فـ [ هو الذي يربط

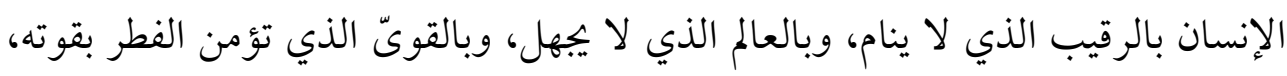

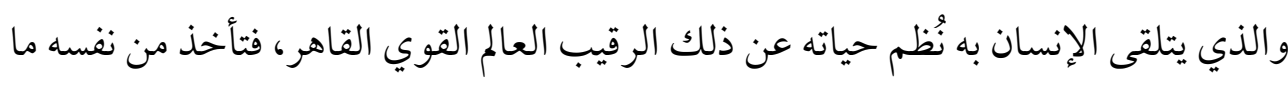

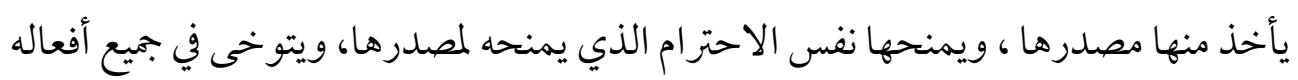

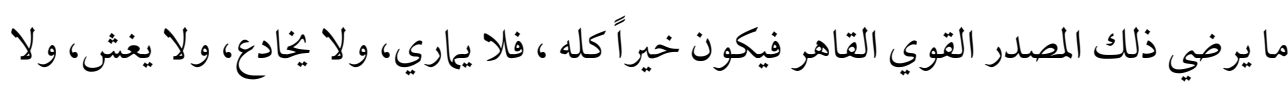

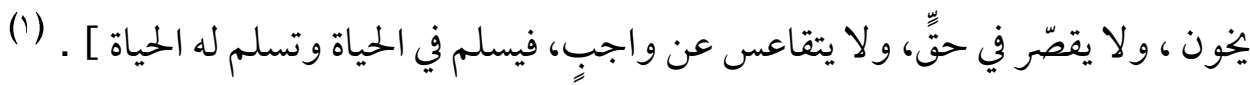
إذن فالضمير هو: تلك القوة الروحية التي تحكم مواقف الإنسان وتفكيره، فتجعله يميّز بين الخطأ والصواب، وهو منحة الله - عزّ وجلّ - للإنسان يدله من خلاله على ما فيه خيره

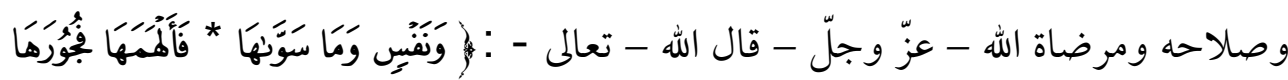

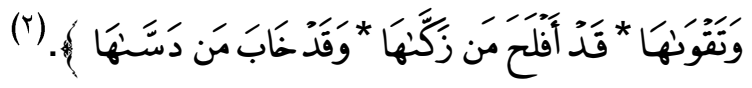
قد أقسم الله - تعالى- بالنفس والذي سواها وأحكم أمرها ومنحها القوى والغرائز التي

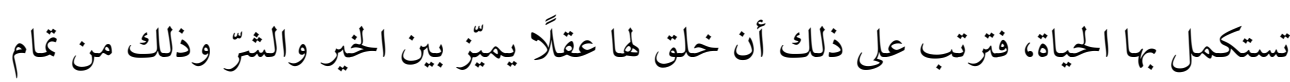

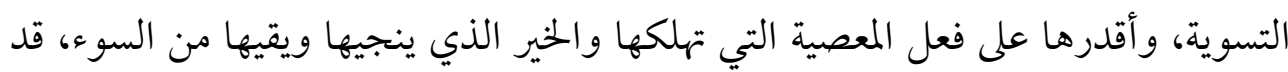

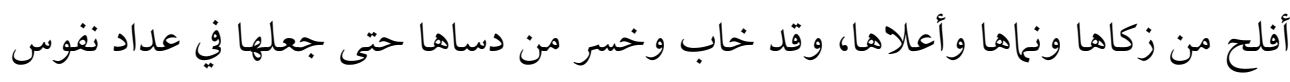

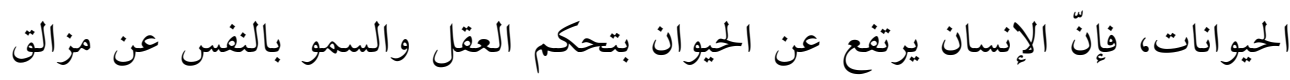

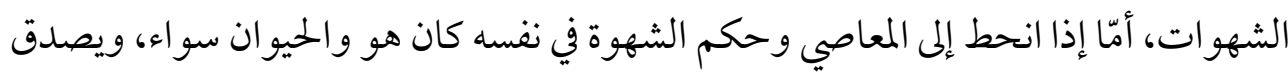

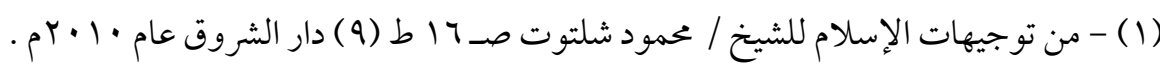

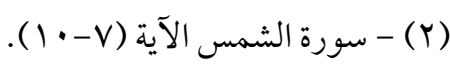


عليه: أنّه دسى نفسه و أنقص مرتبتها، وجعلها في عداد نفوس الحيو انات التي تحكمها شهوتها

(') (1) (1)

[ فالضمير أساس الدين وجوهره، وإذا استعمل الإنسان ضميره بالشكل الصحيح، فإنّه سيشعر برغبة شديدة في معرفة الخالق - سبحانه -، وستصبح هذه الرغبة هي الهدف الوحيد في حياته، وسيكتشف بأنه بأمسّ الحاجة إلى الله الذي خلقه وأوجده من العدم، وأسبغ عليه بنعمة الحياة، وأن القوة كلها بيد الله - تعالى -، إن الإنسان الذي يفكر في وجوده متجاهلا صوت ضميره لا بد وأن يتساءل عن هدف وجوده، وسيكتشف بفطرته خلال رحلة بحثه عن الإجابة عليه بأنّ عليه: العودة للقرآن الكريم ووحي الله - تعالى - ، وأهم ما يفعله عندما ينوي قراءة القرآن أن يكون ضميره يقظًا، ويقر أه مخلصا النية، وأن يطبق ويعيش عملياً

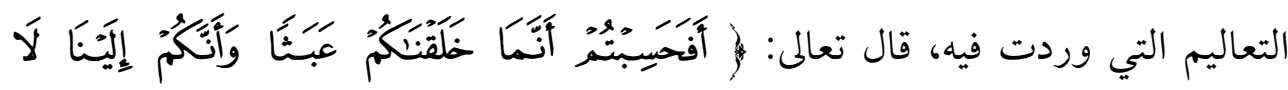

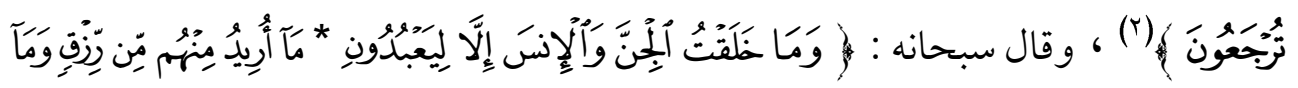

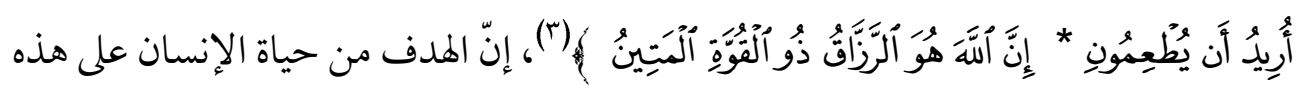

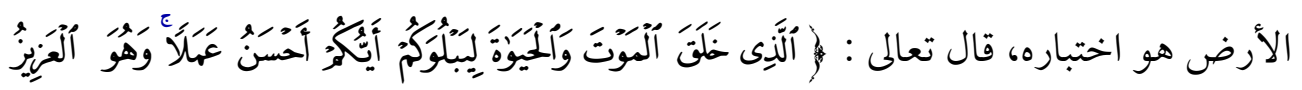

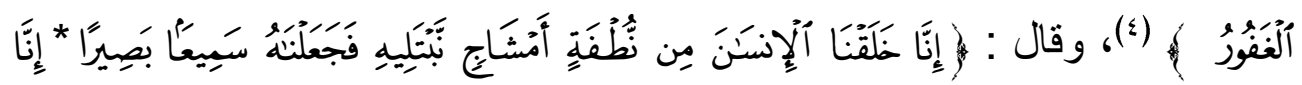

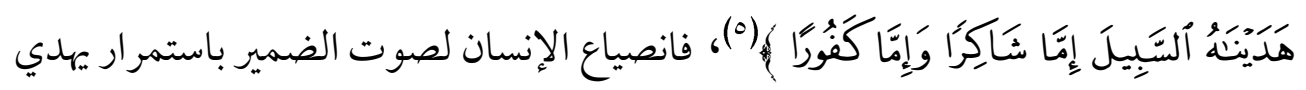
إلى الخُّق القرآني، فعندما يصل الإنسان إلى اليقين بوجود الله - تعالى - واليوم الآخر يصبح

$$
\begin{aligned}
& \text { (1) - التفسير الواضح د/ محمد محمود حجازي س/179. }
\end{aligned}
$$

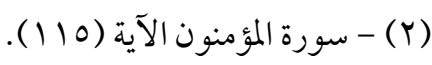

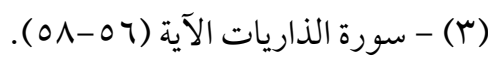

$$
\begin{aligned}
& \text { (ع) - سورة الملك الآية (r). } \\
& \text { (0) - سورة الإنسان الآية (Y-Y). }
\end{aligned}
$$




\section{0}

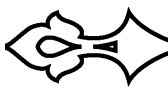

هدفه الأوحد هو: أن يسأل الله في كلّ أفعاله رضاه والجنة ، فمن غير المعقول أن يتصرف

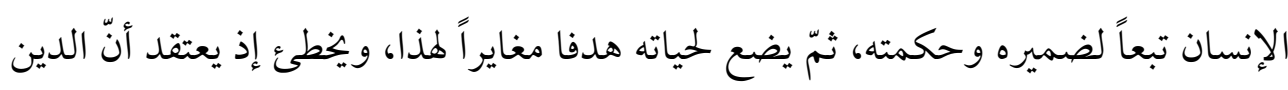

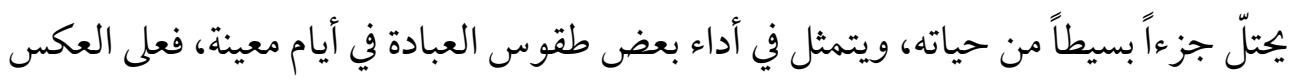

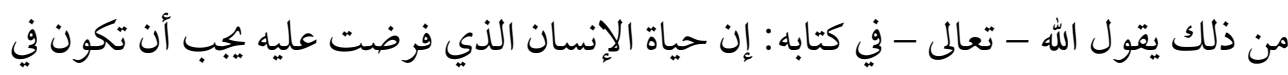

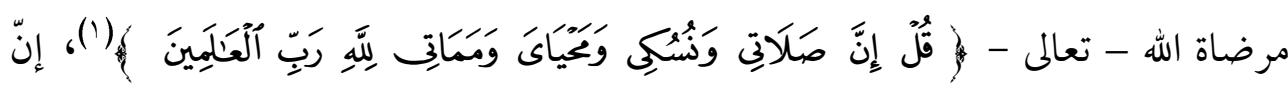

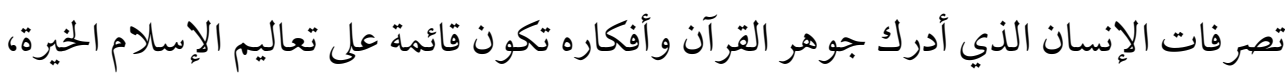

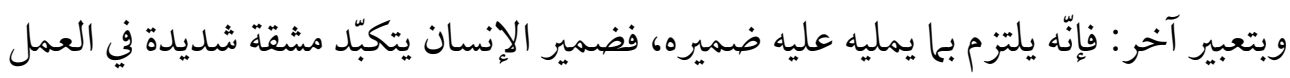

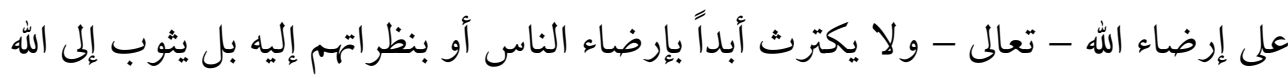
وحده. (n)

إنّ صوت الضمير الإنساني يحرّك في الإنسان العدالة ومكارم الأخلاق والاستقامة والتواضع

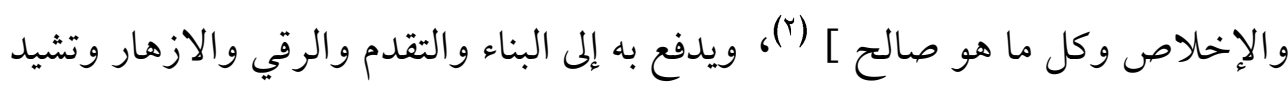

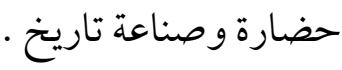
ولمّا كان الضمير الإنساني على درجة وثيقة بالمرض النفسي بها يترتب عليه من قلق

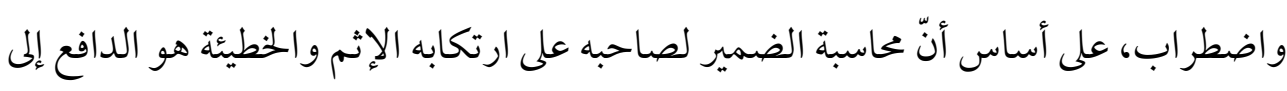
ما يصيبه من عوامل القلق والاضطراب، ولذلك ستتحدث عن الآفات الروحية .

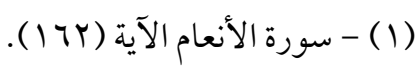
(Y) - أهمية الضمير في القرآن د / هارون يميى صـ Y و وما بعدها ترجمة ومر اجعة / مصطفى الستيتي. مी 
المطلب الثالث : آفات البنائ الروحي وكيفية علاجه في ضوئ القرآن الكريم :

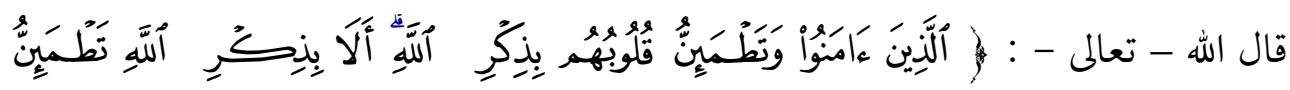

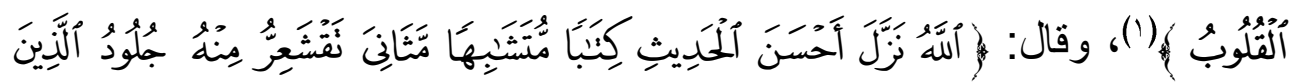

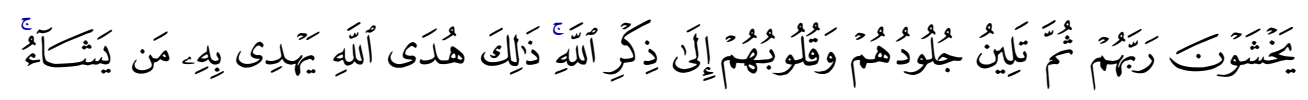

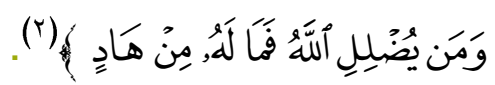
فالنفوس أنفر شيء عن حديث الوعظ و النصيحة، فما لم يكرر عليها عودًا عن بدء لم يرسخ فيها ولم يعمل عمله، ومن ثم كانت عادة رسول الله صلى الله عليه وسلم أن يكرر عليهم ما كان يعظ به وينصح ثلاث مرات وسبعا؛ ليركزه في قلوبهم، ويغرسه في صدورهم، فالمؤمنون إذا سمعوا بالقرآن وبآيات وعيده تعالى: أصابتهم خشية تقشعر منها جلودهم، ثمّ إذا ذكروا الله ورحمته وجوده بالمغفرة لانت جلودهم وقلوبهم وزال عنها ما كان بها من الخشية

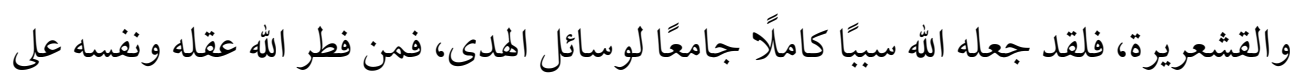
الصلاحية لقبول الهدى سريعًا أو بطيئًا اهتدى به، كذلك ومن فطر الله قلبه على المكابرة، أو على فساد الفهم ضلّ فلم يهتد حتى يموت على ضلاله، فأطلق على هذا الفطر اسم الهدى واسم الضلال، وأسند كلاهما إلى الله؛ لأنّه هو جبار القلوب على فطرتها وخالق وسائل ذلك، لكّل ومدبّر نو اميسه و أنظمته.

[ إنّ الاستقر ار النفسي يُعدّ من العوامل الهامة التي تساعد على البناء المتكامل للإنسان بحيث

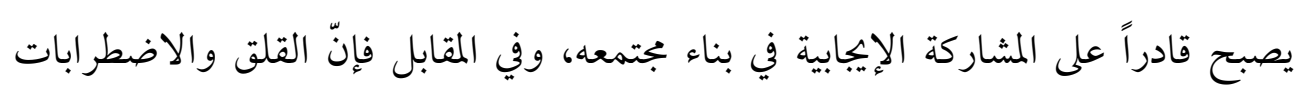
النفسية تعدّ معوقاً من معوقات هذا البناء، فاليد المرتعشة لا تقوى على البناء، والفكر

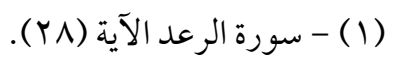

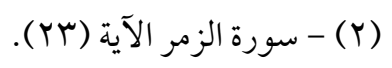




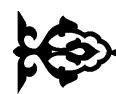

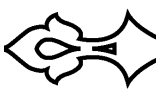

المضطرب لا يساعد على الثفكر والتأمل، والنفس الشاردة لا يمكنها مشاركة الآخرين في

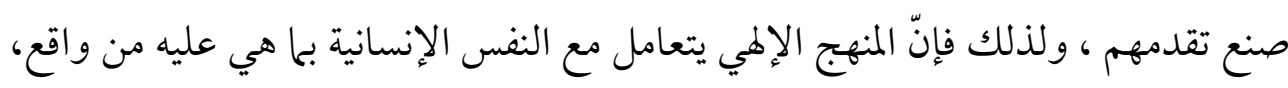

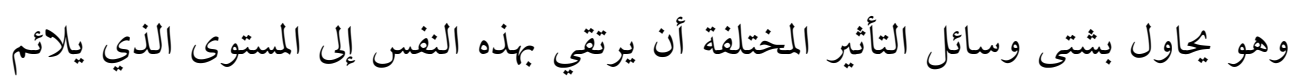

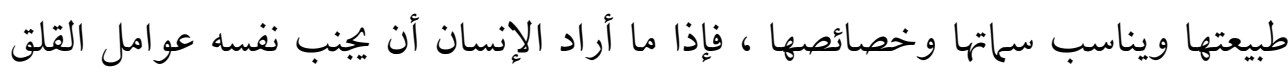

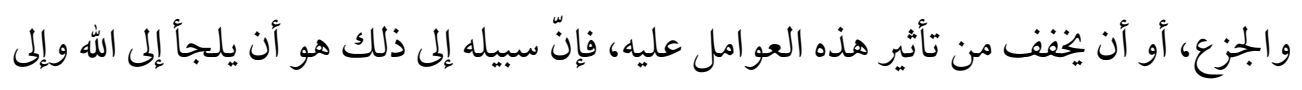

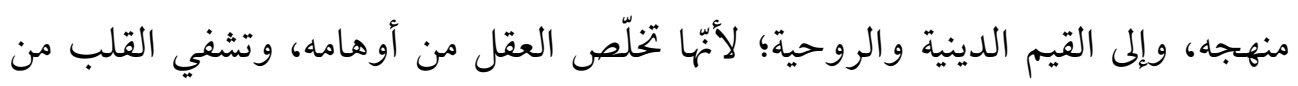

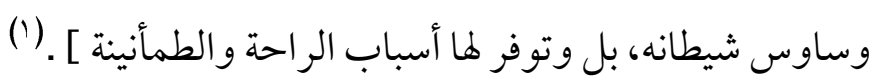

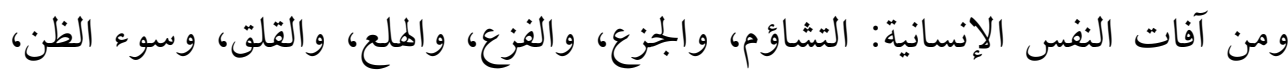

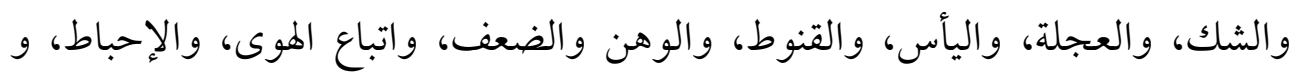

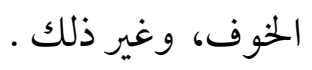

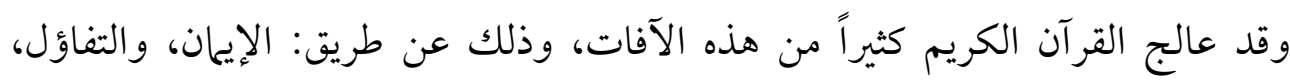

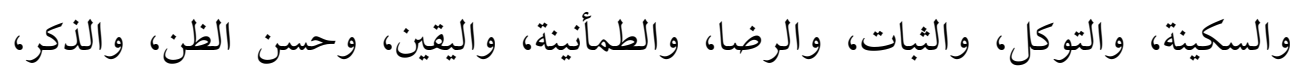
و القناعة، والاستعانة بالصبر والصلاة .

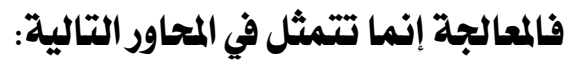

الأول: الإيمان والصحة النفسية: من حيث إن الإيمان اطمئنان قلبي، فيه يجد سكونه وأمنه،

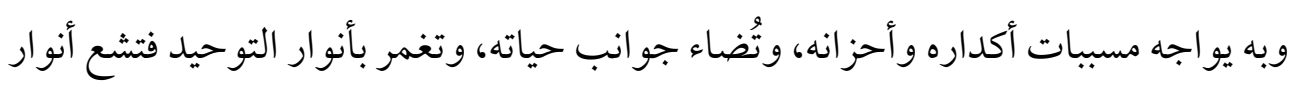
التوحيد على سائر جوارحه، وبه يمتلئ يقينا وثباتا فلا تزعزعه الأهواء، قال تعالى : (إنَّمَا

(1) - الإسلام والبناء الروحي والعقلي للإنسان للأستاذ / عبد التواب إبراهيم رضوان صـ AV ، كو بتصرف .

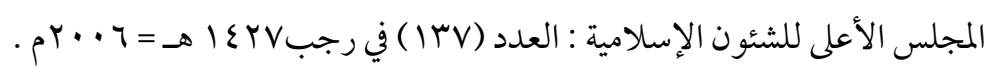
क्षेत्र 


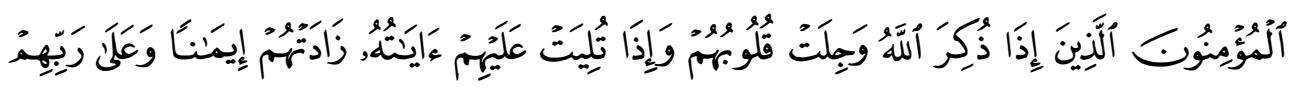

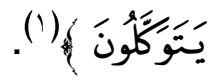

الثاني: القدرة على مواجهة الشدائد والصعاب: تعتبر هذه القدرة بمثابة طاقة نفسية تساعد الإنسان على الاحتفاظ بثباته واتزانه في مواجهة مشكلات الحياة ومعوقاتها، ذلك الثبات والاتزان الذي يقوى به الإنسان على عو امل الضعف والوهن و الانطواء والانعز الية، والذي يساعد على تخطي الصعاب والمعوقات التي تعترض طريقه، ولقد بيّن القرآن الكريم الأسلوب السليم لرعاية هذه القدرة ، وذلك فيما ذكره لقمان الحكيم لابنه في وصيته الخالدة :

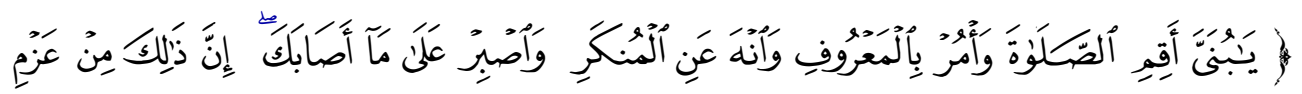

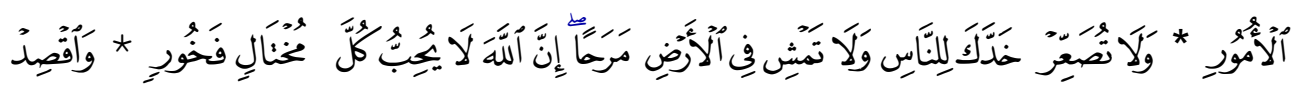

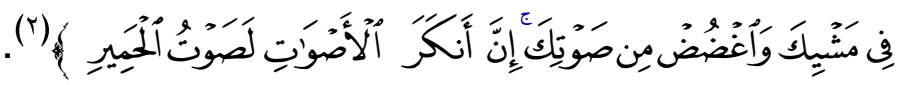

إذ جمع لقمان لابنه الإرشاد إلى فعله الخير، وبثّه في الناس، وكفّه عن الشر، وزجره الناس عن ارتكابه، ثم أعقب ذلك بأن أمره بالصبر على ما يصيبه، ووجه تعقيب الأمر بالمعروف والنهي عن المنكر بملازمة الصبر؛ لأنّ الأمر بالمعروف والنهي عن المنكر قد يجران للقائم بها معاداة من بعض الناس أو أذى من بعض، فإذا لم يصبر على ما يصيبه من جراء الأمر بالمعروف والنهي عن المنكر أو شك أن يتركها، ولما كانت فائدة الصبر عائدة على الصابر بالأجر

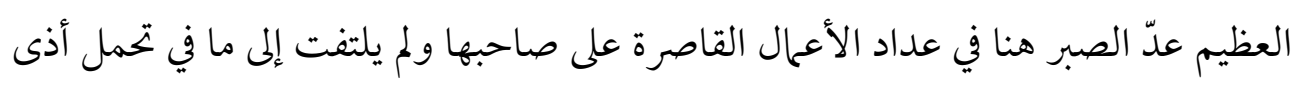
الناس من حسن المعاملة معهم حتى يذكر الصبر مع قوله "ولا تصعر خدك للناس" . (")

$$
\begin{aligned}
& \text { (1) - سورة الأنفال الآية (r). }
\end{aligned}
$$

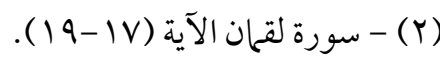

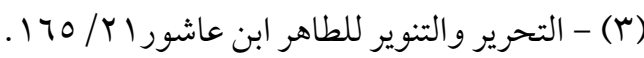




\section{0}

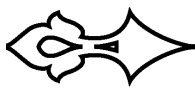

الثالث: القدرة على إقامة علاقات سليمة مع الآخرين: فالإنسان السويّ من الناحية النفسية

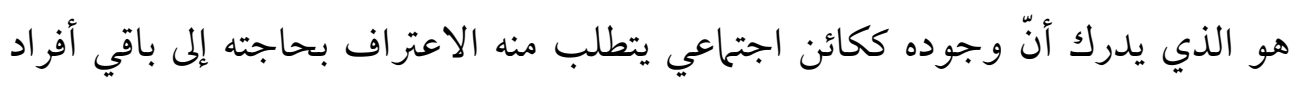

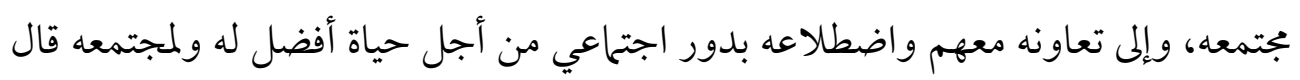

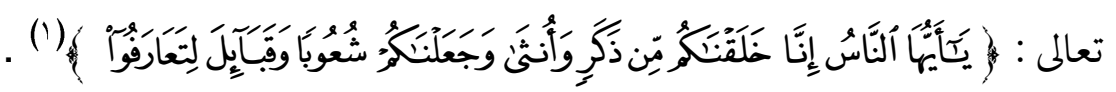
الرابع: القدرة على الأخذ والعطاء والتضحية: حيث حبب المنهج الإلمي إلى المؤمنين به أن

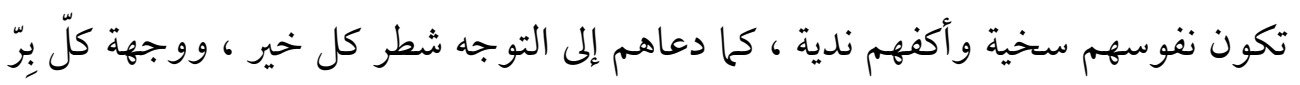

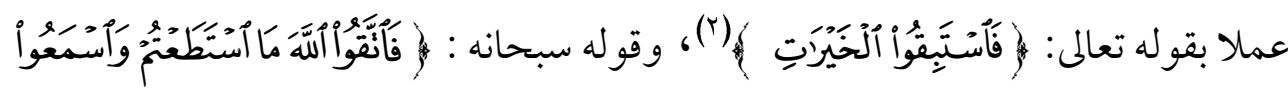

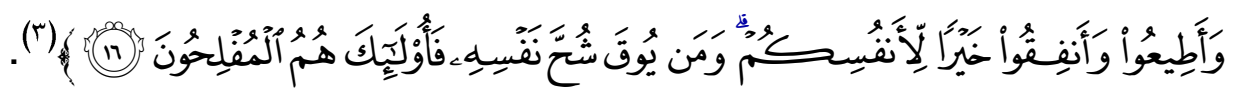

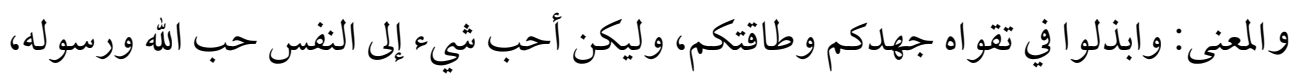

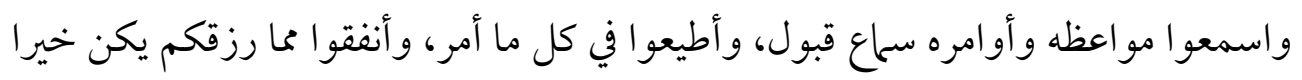

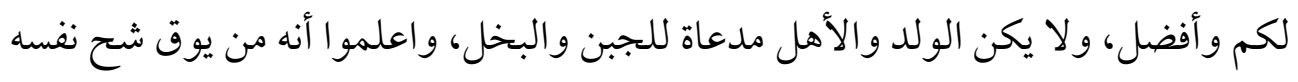

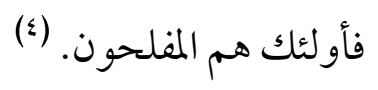
الخامس : القدرة على السمو بالغرائز والتسامي بها : وذلك وفق القيم الدينية والأخلاقية ،

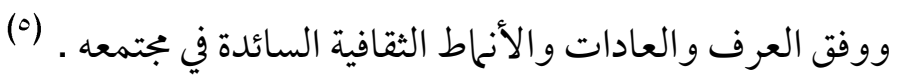

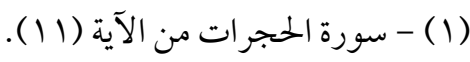

$$
\begin{aligned}
& \text { (Y) - سورة البقرة من الآية (N乏乏) ( ). } \\
& \text { (Y) - سورة التغابن الآية (Y (1). }
\end{aligned}
$$

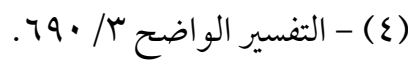

$$
\begin{aligned}
& \text { (0) - الإسلام والبناء الروحي والعقلي للإنسان صـ بهو وما بعدها بتصرف ـ }
\end{aligned}
$$




\section{المبحث الثاني : بناي الإنسان فكريا وعقليا :}

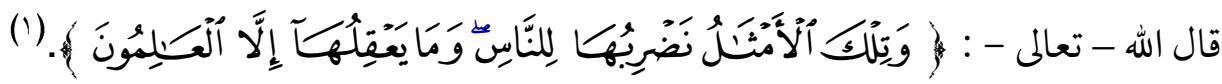
فالعقل من أعظم نعم الله على العباد، جعله الله فرقاً بينه وبين الحيوان بها أودع فيه من طاقة للحكم على الأمور، واستخلاص النتائج من مقدماتها، والغوص إلى معرفة الحقائق الكونية، والاستدلال بها على عظمة الخالق سبحانه، وكمال قدرته وحكمته من خلال رؤية إتقان المخلوقات وإحكامها، وتمكينه من استغلال ما أودع الله في الكون من المصالح وفق مراد الله سبحانه وتعالى.

ولذلك لم يكن العقل والتفكير فريضة في الشريعة الإسلامية بل كان من الكليات الخمس التي اتفقت عليها الشرائع السماوية والرسالات الإهية التي جاءت بها الرسل إلى البشرية .

\section{الاطلب الأول : العقل ومقاصد الشريعة الإسلامية :}

العقل هو : أداة التفكير التي يعمر بها الكون وتدبر الحياة ويتلقى به شرع الله، وإذا عدم هذا العقل اختل نظام الحياة، لذا كان حفظ العقل ضرورة تجب مراعاته وعدم التفريط فيه ؛ لأنه مناط التكليف ، فإن فُقد العقل مطلقاً كالمجنون جنوناً مطبقاً ، فليس أهلاً للتكليف مطلقاً ، و إن كان فقده في وقت وعاد إليه في وقت آخر كمن جنونه غير مطبق، فإنه يكون مكلفاً وقت برئه وليس بمكلف وقت جنونه ، وإن كان عقله ناقصاً نقصاً مخلاً بصحة تصوره كالصبي فانه ليس أهلا للتكليف بالواجبات ، وفي حديث علي - رضي الله عنه - عن النبي صلى الله

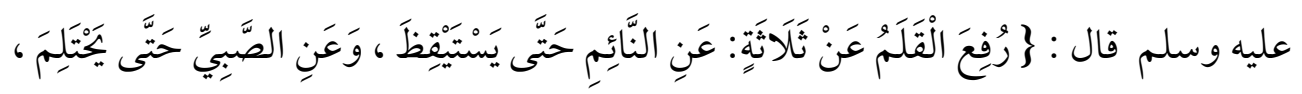

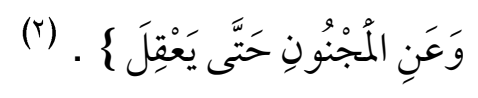

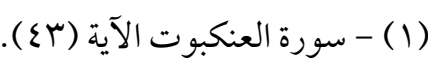

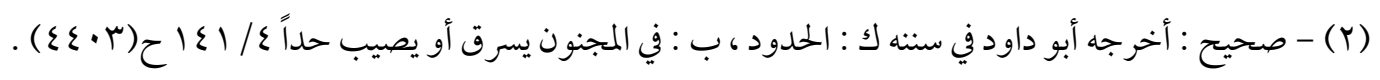




\section{0}

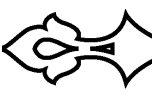

قال الآمدي : \} اتفق العقلاء على أن شرط المكلف : أن يكون عاقلا فاهما للتكليف ; لأن

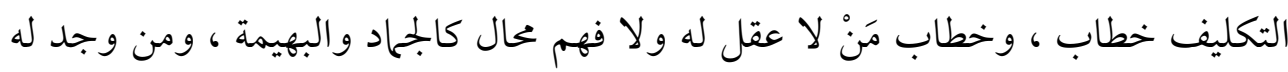

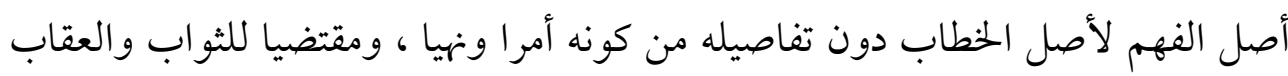

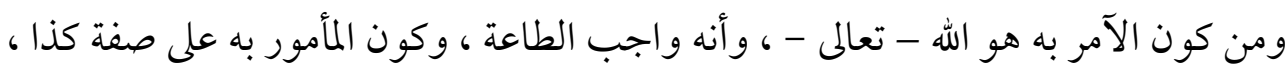
و كذا كالمجنون والصبي الذي لا يميز ، فهو بالنظر إلى فهم التفاصيل كالجماد والبهيمة بالنظر

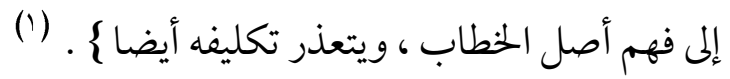

ولذلك اهتم الإسلام بالعقل اهتماما كبيراً ؛ فهو الذي من خلاله يستطيع الإنسان أن يميّز بين

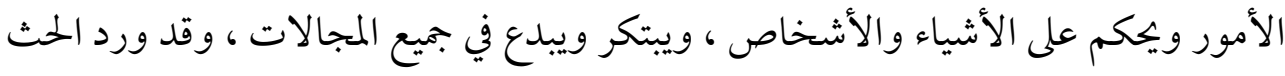
على العقل والتفكير والتدبر والتفقه في العديد من آيات القر آن الكريم ، فني العقل ومشتقاته

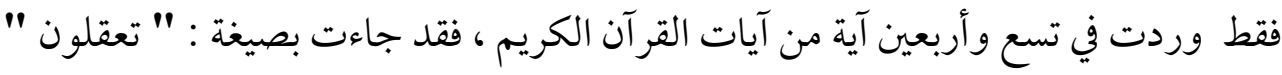

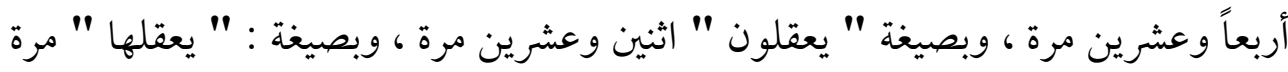
و احدة ، وبصيغة : "نعقل "مرة واحدة ، وبصيغة : " عقلوه " مرة واحدة .

[ ومن خلال النظر في الأساليب القرآنية الواردة في هذا الشأن نجد أن القرآن الكريم يحفز

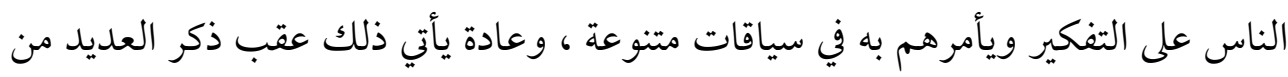
آيات الله الكونية أو الإنسانية ، أو الحديث عما يتضمنه القرآن الكريم من حكم بالغة ، أو بعد

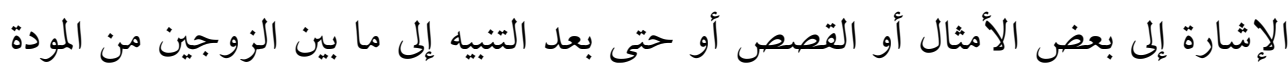
(1) - الإحكام في أصول الأحكام / / 10 ت / عبد الرزاق عنيفي ط : المكتب الإسلامي - بيروت . (1) 
و الرحة ، أو غير ذلك من أمور تتطلب من الإنسان أن يشحذ ذهنه وعقله لفهمها وإدراك ما

$$
\text { تنطوي عليه من سنن وأسرار إلهية ] . ( ) }
$$

وعليه فالبناء الفكري للإِنسان في جوهره يعني : تنمية العقل البشري ورعايته ، وتحريره من كل ما يعوق حركته و انطلاقته ، ثم دعوته إلى التأمل في صنع خخلوقاته ، والحث على طلب العلم والاستز ادة منه ، وكل ذلك يظهر جليا من خلال معرفة الوظيفة التربوية للعقل .

\section{المطلب الثاني : الوظيفة التربوية للعقل :}

إنّ القرآن الكريم فيه من المواقف و الوقائع التي تتضمن ضرورة التعقيل لما لا بد من الانتباه

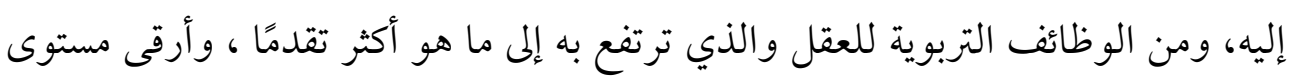

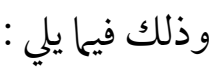

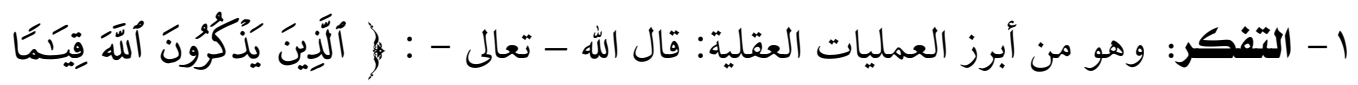

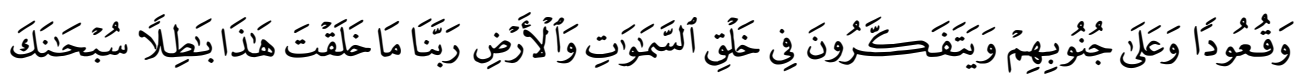

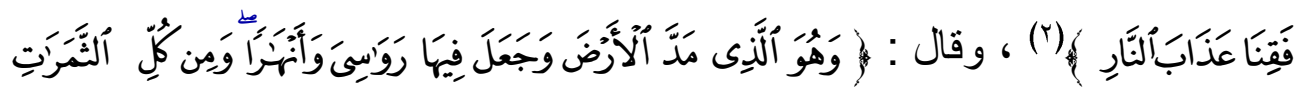

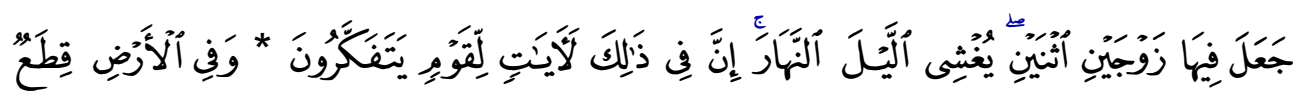

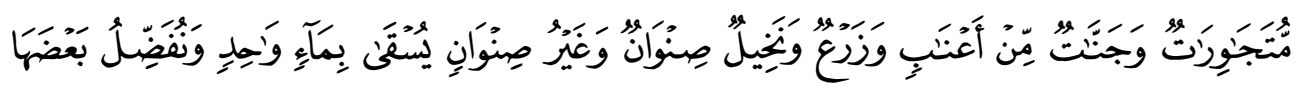

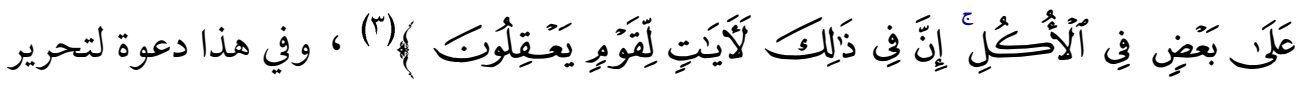
العقل الإنساني من صور الخرافة والوهم ؛ حتى يكون مهتديا إلى سبيل الحق ، داعيا

(1) - الإنسان والقيم في التصور الإسلامي أ ـ د / محمود حمدي زقزوق صـ 1؟ ـ هدية بجلة الأزهر لشهر رمضان

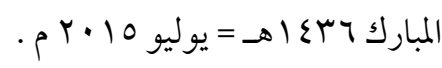

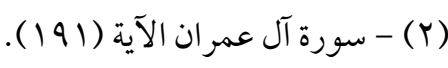

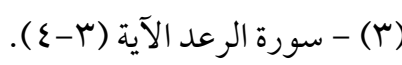




\section{5}

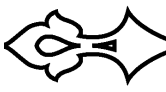

بالاحتكام إليه في معرفة حقائق الوجود ، فاصلا بين قضايا الشك واليقين ، ولم تكن الدعوة إلى تحرير العقل إلا مدخلا صحيحاً لدعوته إلى التأمل والتفكر . r- التفقه والتدبر، وهو: التفكر في المعاني المستخلصة، والوعي بالأسس والمبادئ، والادراك

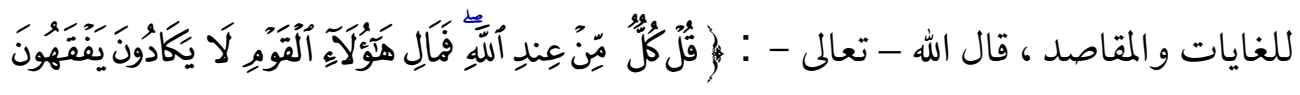

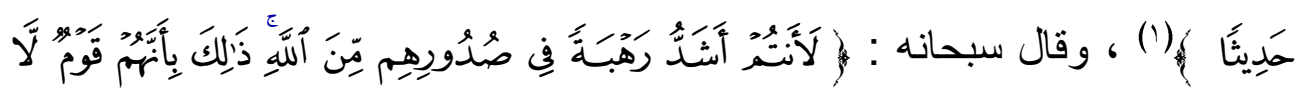

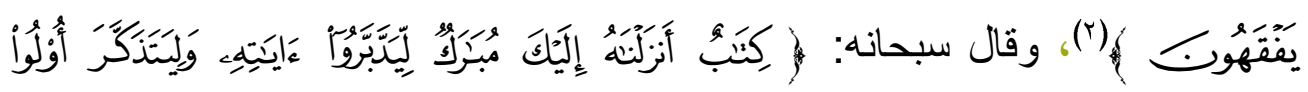

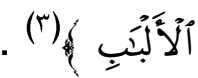

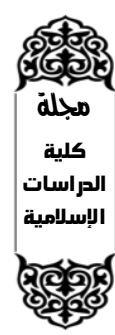

r- الاستنباط والاعتبار: وهو من العمليات المنطقية الأساسية للربط بين المتناثر من الأفكار، واستخراج ما خفي من المعاني، والبحث عن المضامين غير المعلنة، فالقرآن كله كتاب هداية ومنهج حياة، وفي قصصه عبرة لأولي الألباب، وفيه بيان مشرق لكل ما يحتاجه الناس في دنياهم، وكشف عما يلقونه في أخراهم بأسلوب يخلو من الغموض و الالتباس قال الله - تعالى

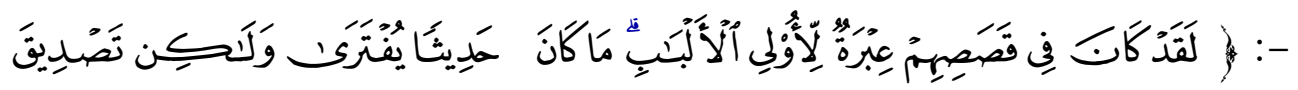

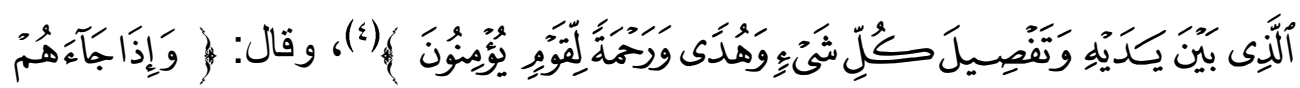

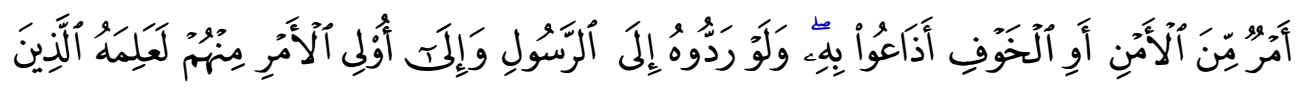

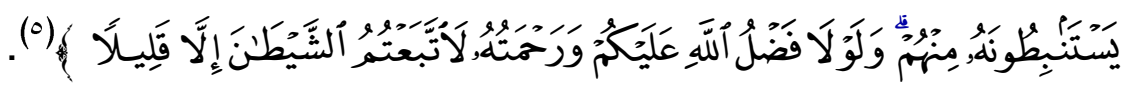

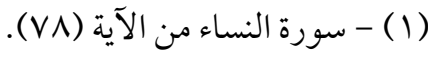

$$
\begin{aligned}
& \text { (Y) - سورة الحشر الآية (r)). } \\
& \text { (r) - سورة ص الآية (Y)). } \\
& \text { (ع) - سورة يوسف الآية (11). } \\
& \text { (0) - سورة النساء الآية (N)). }
\end{aligned}
$$




\section{$\overbrace{0}^{3}$}

ع- العلم والمعرفة: إن العلم الذي يقره منهج الإسلام ليس علماً معيناً بذاته ، إنه يقرّ العلم الذي يوسع آفاق الفكر ويزيل المعوقات أمام التفكير العقلي ، والذي يوثق صلة الإنسان بالوجود ، ويفتح له مجالات أوسع أمام الكشف والإدراك ، ويتيح له السيادة في الكون ، والتحكم في

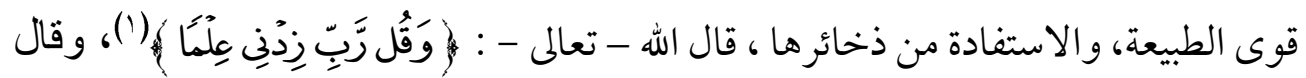

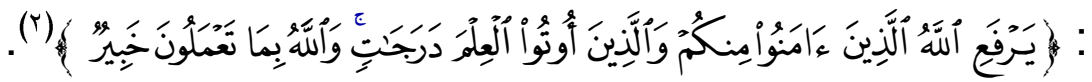
وقبل طيّ صفحة هذا المطلب نود أن نشير إلى أساليب تنمية القدرات العقلية ؛ ليكون الإنسان مشاركاً مشار كة إيجابية في عملية التنمية ، وهي :

1 - تدريب الإنسان في موقف التعلم على التفكير الشامل بدلا من التفكير الجزئي ؛ لأن التفكير الشامل يقوم على البحث التجديدي بدلا من التفكير التقليدي ، فالتفكير الشامل هو الذي يجيط بالظو اهر من جميع جو انبها ويتحرى جميع عناصرها . ץ- تدريب الإنسان في موقف التعلم على النقد والنقد الذاتي ، وذلك بدلا من التفكير التبريري ، والنقد الذاتي يعني بيان أوجه القصور في تفكير الإنسان ، والاعتراف بهذا القصور والعمل على معالجتها .

ب- تدريب الإنسان في موقف التعلم على التفكير العلمي بدلاً من الظن والهوى ، فالتفكير العلمي يقوم على التروي والتثبت من كل أمر قبل الحكمم عليه بالقبول أو الرفض دون تسرع في إصدار الأحكام أو الاعتماد على الظن والهوى ، وفيه تغلب على التحديات التي أفرزها التطور الهائل في التكنولوجيا . - الت

\footnotetext{
(1) - سورةطه الآية (ع (1)).
}

(Y) - سورة المجادلة من الآية (11). 


\section{F)}

ع- تدريب الإنسان في موقف التعلم على التفكير الجماعي بدلا من التفكير الفردي ، ففيه تنمية

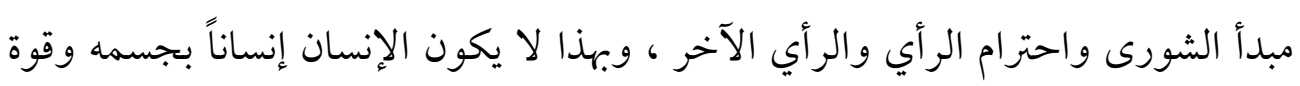

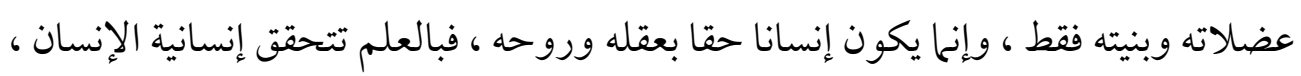

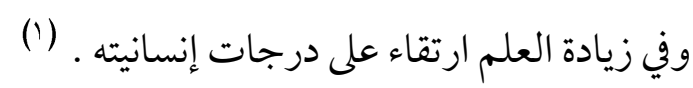

\section{الملب الثالث : مبطلات التفكير السليم :}

مهمة العقل هي أن يؤدي وظيفتين : الأولى : إقامة دين الله الذي يوصل إلى ثوابه ورضاه في

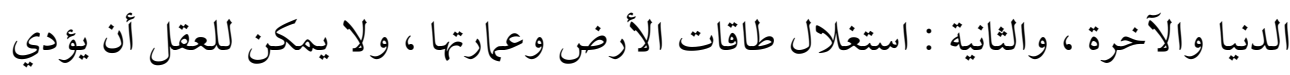

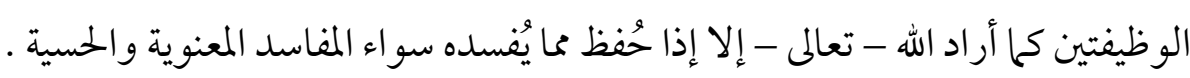
فالمفاسد المعنوية منها : العقائد الفاسدة والخرفات الزائفة ، ففساد العقول بالتصورات

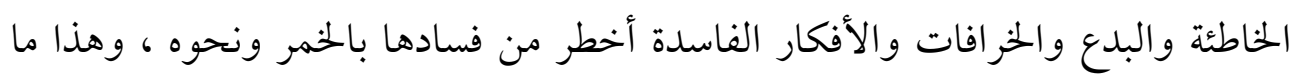

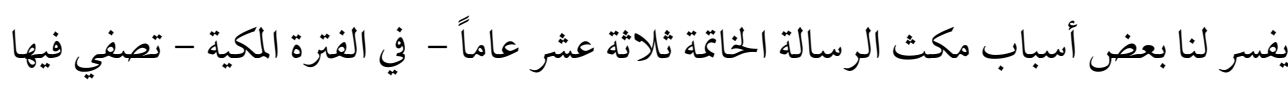

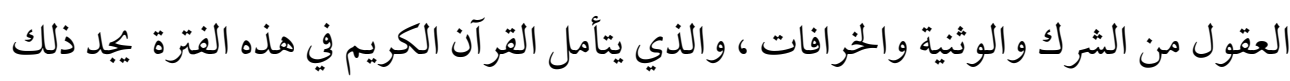

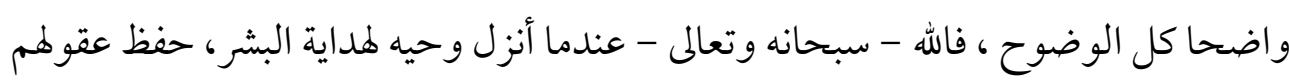

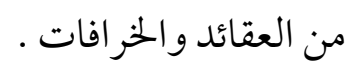
ومنها : سؤال المنجمين والعرافين وتصديقهم في قولهم ، واتباع الهوى .

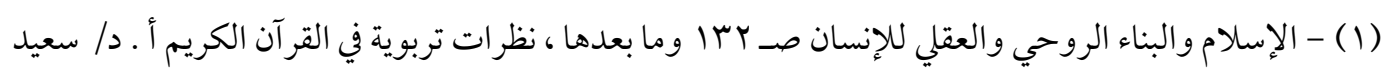

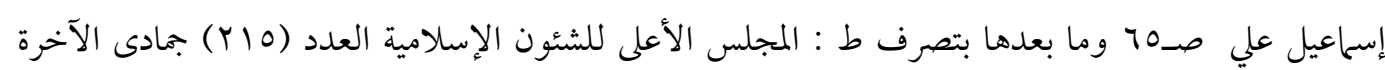

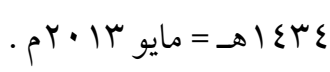
(⿻)丨子 
وهكذا يجب أن تحفظ عقول الناس ، وبخاصة المسلمين من جميع المذاهب الهدامة ، والأفكار الفاسدة التي تفسد العقول سواء كان ذلك عن طريق وسائل الإعلام المختلفة المقروءة منها كالكتب ، أو الصحف والمجلات ، أو المسموعة كالإذاعة أو التلفاز أو غيرها .

أما المفاسد الحسية فمنها : تحريم الخمر والمسكرات والمخدرات والأمور التي تذهب العقل ،

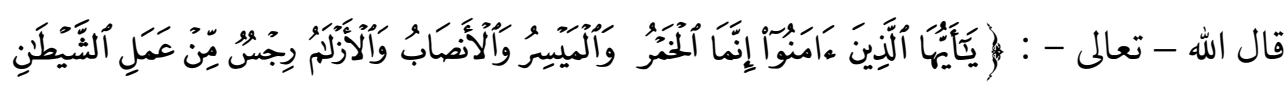

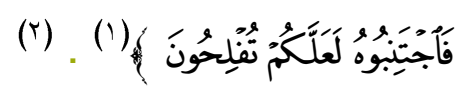

\section{المبحث الثالث : بناي الإنسان جسداً ومادياً ، وفيه مطلبان :}

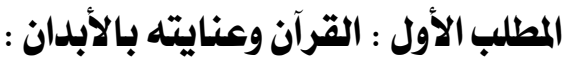

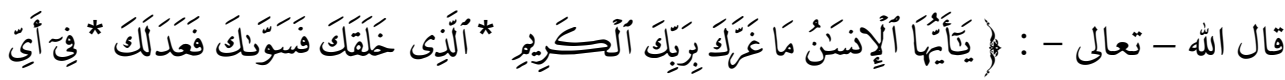

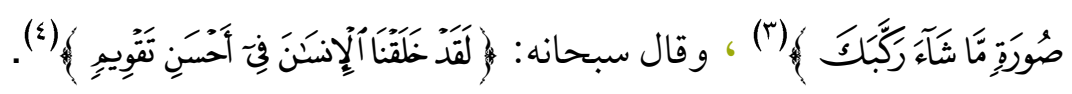
لقد اعتني القرآن بالإنسان من حيث تكوينه وتنشئته ورعايته وكفالته ، متتبعاً إياه في كل مرحلة من مراحل حياته : جنينا - رضيعا - طفلا - غلاما - شابا - رجلا - كهلا - شيخا أي : منذ واقعة الميلاد حتى مفارقة الحياة الدنيا بالوفاة ، لا تستقيم أحوال الحياة إلا باستقامة وصلاح الأحياء ، وقد قالو ا: العلم علمان: علم الأبدان، وعلم الأديان، ولذلك نجد القرآن

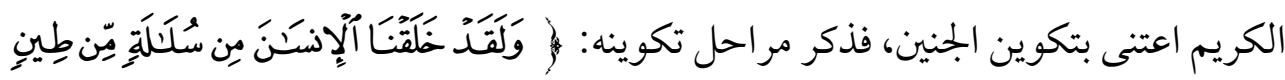

$$
\begin{aligned}
& \text { (1) - سورة المائدة الآية (•9). }
\end{aligned}
$$

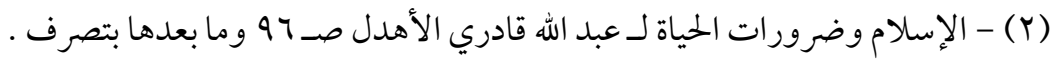

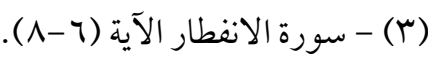

$$
\begin{aligned}
& \text { (ع) - سورة التين الآية (ع). }
\end{aligned}
$$




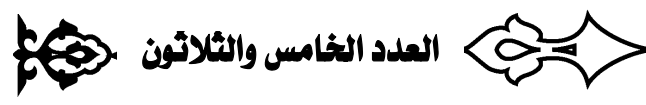

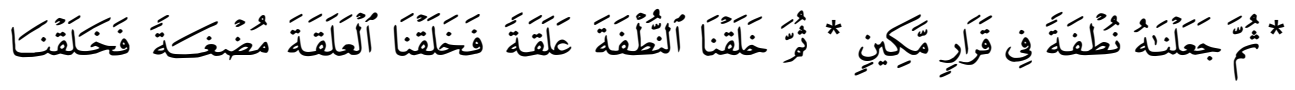

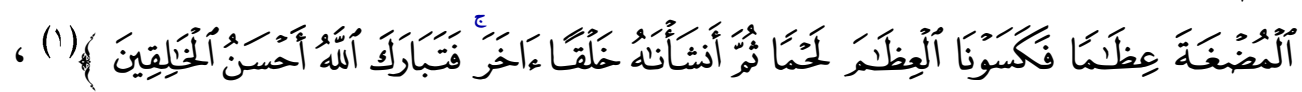

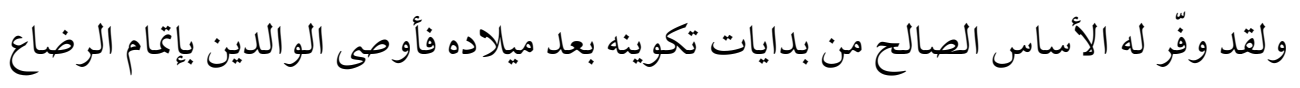

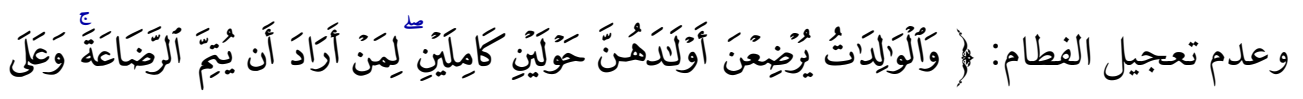

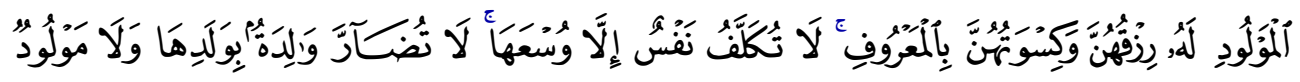

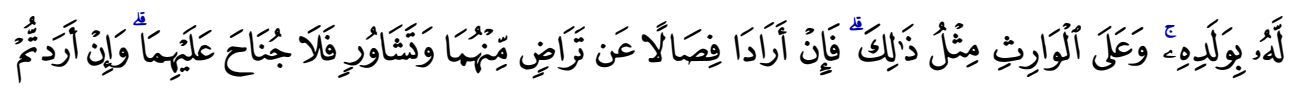

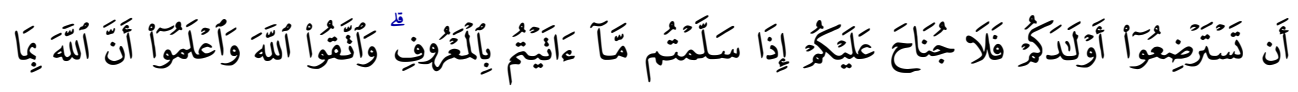

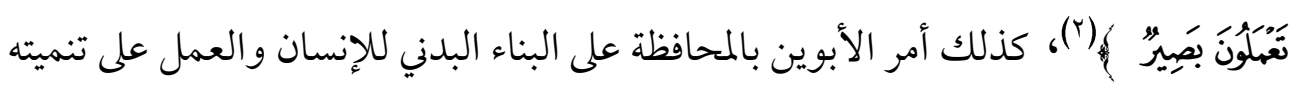

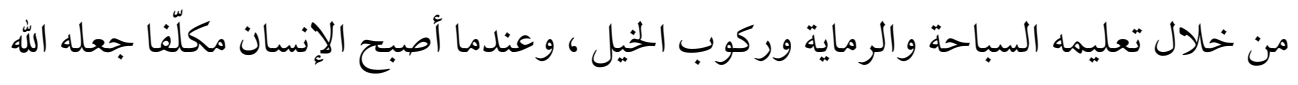

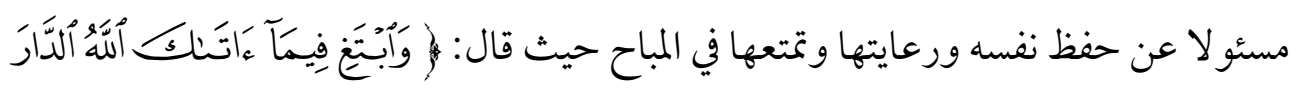

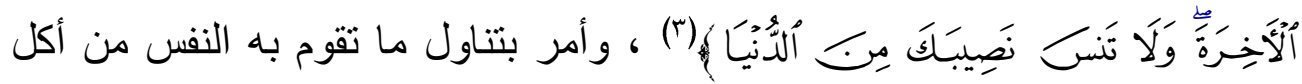

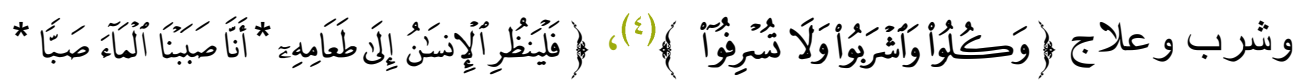

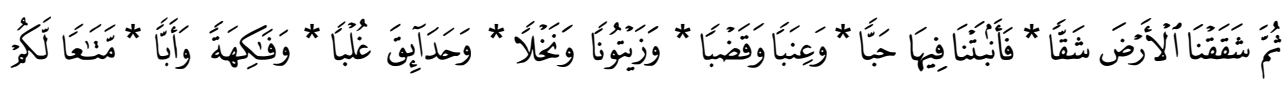

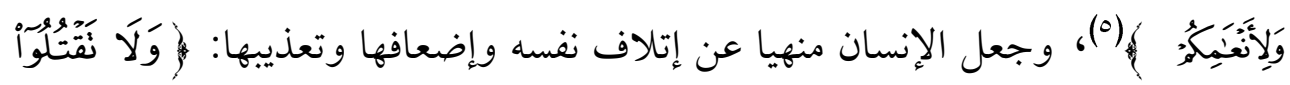

$$
\begin{aligned}
& \text { (1) - سورة المؤمنون الآية (Y (1-ع ()). } \\
& \text { (Y) - سورة البقرة الآية (TrY). } \\
& \text { (r) - سورة القصص من الآية (VV). } \\
& \text { (ع) - سورة الأعراف من الآية (1) (ب). }
\end{aligned}
$$

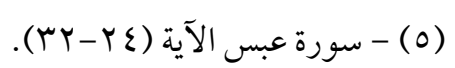




\section{3}

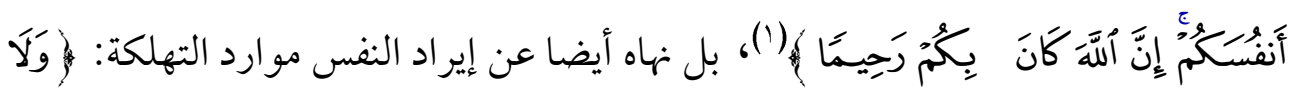

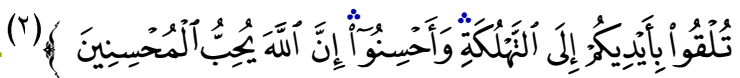

وبالجملة : لقد شُرع من أجل حفظ النفس أحكام كثيرة منها : منع القتل ، وتشريع القصاص ، ومنع التمثيل والتشوية ، ومعاقبة المحاربين وقطاع الطريق والمستخفين بحرمة النفس البشرية ، ومنع الاستنساخ البشري ، و التلاعب بالجنيات ، و المتاجرة بالأعضاء ، والتشريح لغير ضرورة معتبرة ، وحرق أجساد الموتى ·

وكان من حرص الإسلام على سلامة النفس وصيانتها والحفاظ عليها أن شمل ذلك حتى في تأدية التكاليف والقيام بواجب الشرع ، فقد أخرج البخاري في صحيحه عَنْ أَنَسِِ بْنِ مَاللِكِ

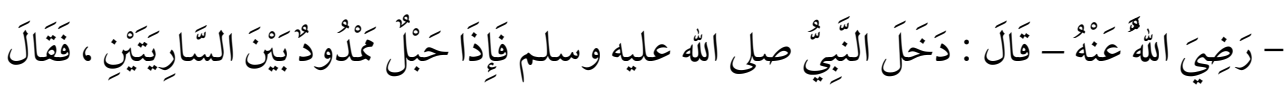

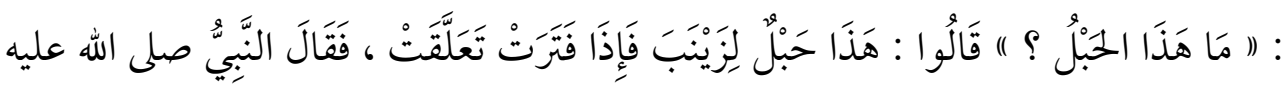

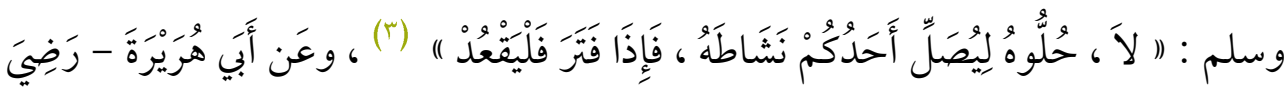

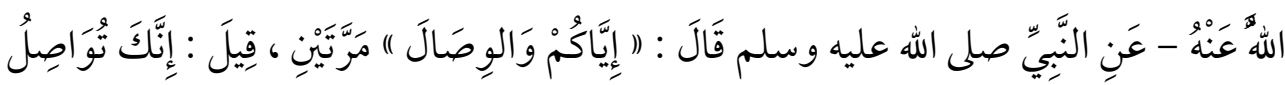

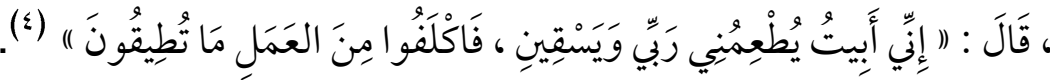
كما أنّه شنّع على الذين يريدون أن يمنعوا النفس حقها من المتعة و أكل الطيبات ، فقد أخرج

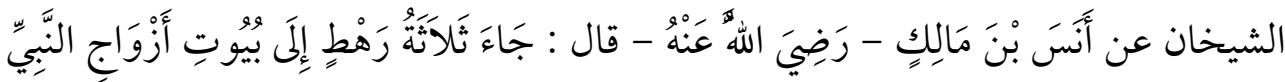

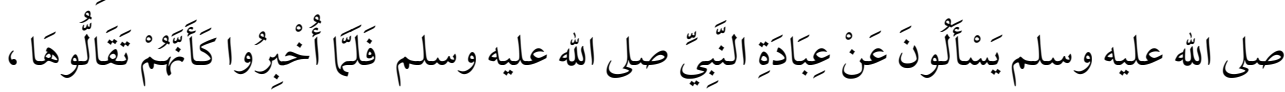

$$
\text { (Y) - سورة النساء من الآية (Y9). (Y) - سورة البقرة من الآية (190). }
$$$$
\text { (r) - البخاري في صحيحه ك : التهجد r/ ro ح( (100) دار طوق النجاة . }
$$

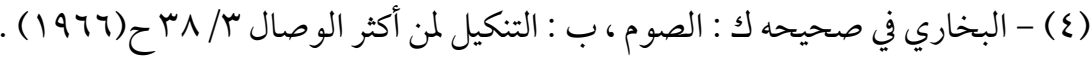




\section{0}

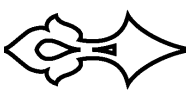

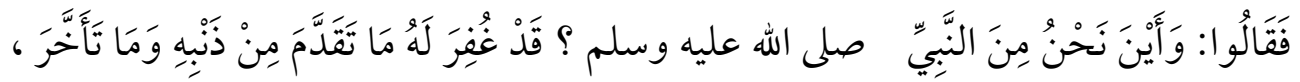

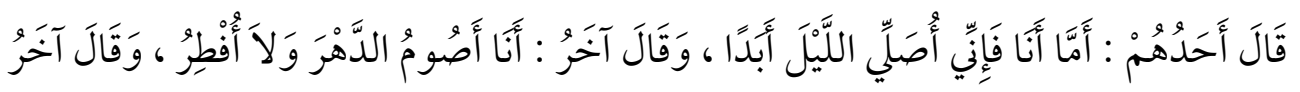

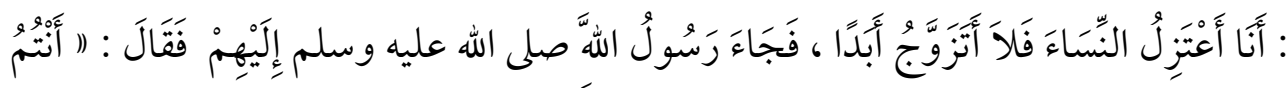

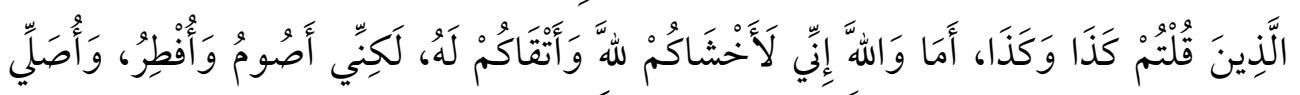

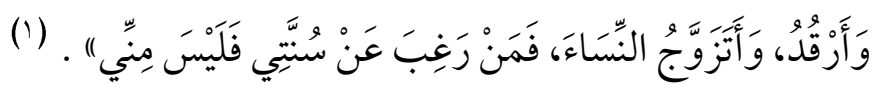
فالشرع يريد من الإنسان أن يكون سليم الجسم ، قوي البنية ، قادراً على مواجهة الصعاب

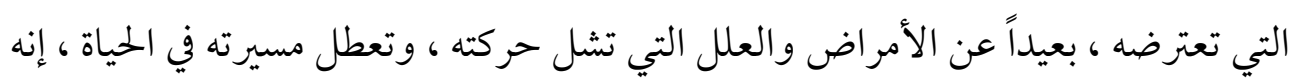

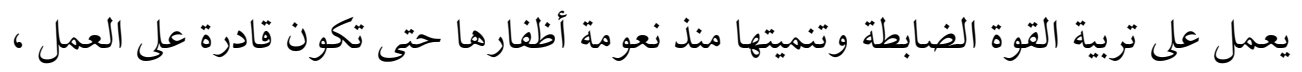

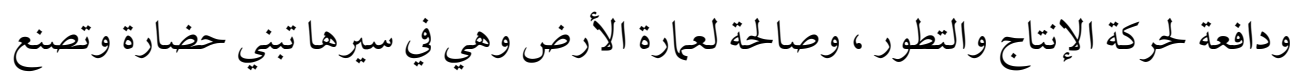
تاريخاً.

\section{المطلب الثاني : التدابير الوقائية في المحافظة على أعضاء الإنسان الجسمية :}

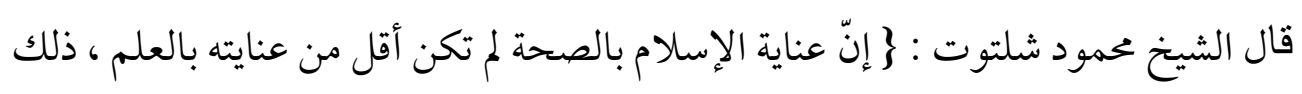

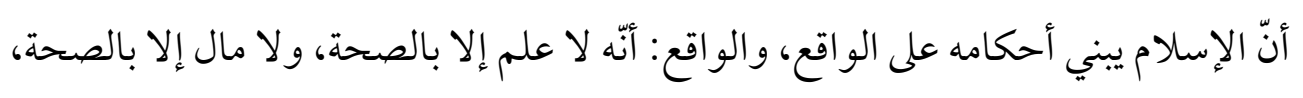

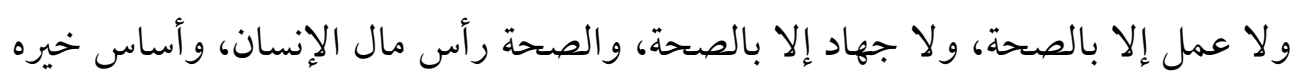

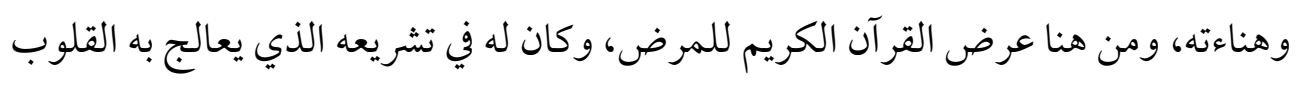

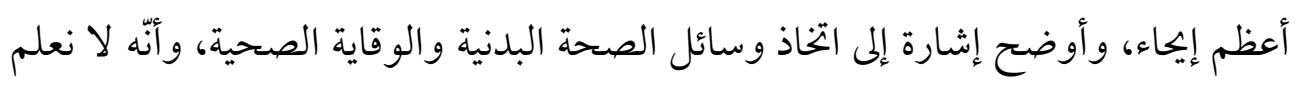

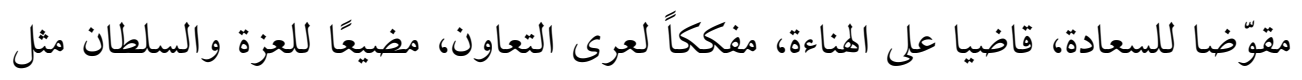

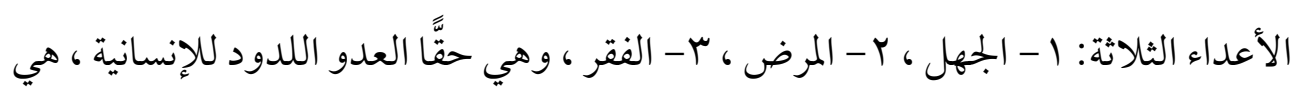

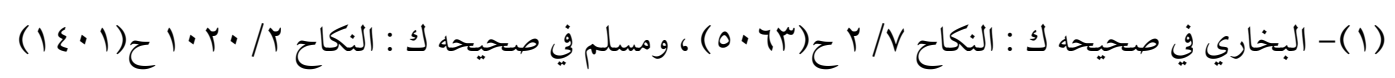

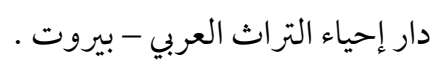
(⿻)丨 


\section{3}

العدو الذي يجب أن تحشد له القوى بصدق وإخلاص ، وعزم وحزم حتى تنقذ الإنسانية من

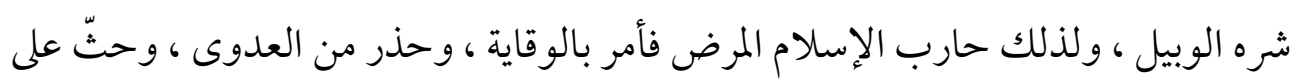

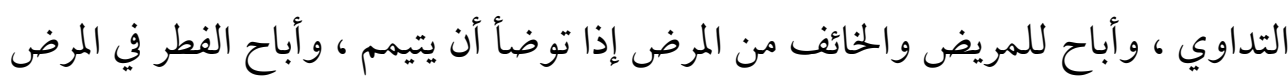
والسفر والحيض والنفاس والحمل والإرضاع والشيخوخة ، كلّ ذلك عناية بالصحة ، ووقاية من المرض ، وقد استقر ذلك في نفوس المسلمين حتى اشتهر أن صحة الأبدان مقدمة

(1) على صحة الأديان وهناك أمور ذكرها الإسلام وأوضح أنها من الأشياء التي تحافظ على بنيان الإنسان ، منها : أ- نظافة الإنسان : فيحمله على غسل بعض أعضاء جسمه عدة مرات في اليوم ، وعلى غسل جميع جسمه في مناسبات خاصة ، ويحثه على أن يحتفظ بنظافة ثوبه وبدنه وفمه عند الاجتماع و اللقاء على نحو ما يحدث في صلاة الجمعة .

ب - غذاء الإنسان وشرابه : فيحرّم عليه بعض ألوان الطعام ، كما يحرم عليه بعض أنواع

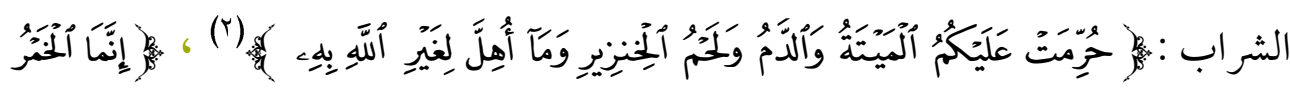

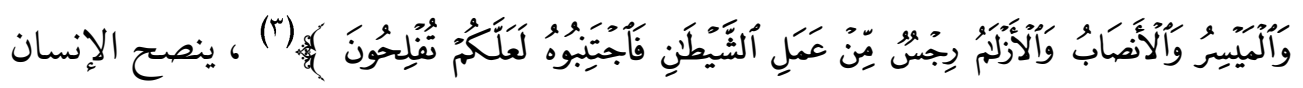

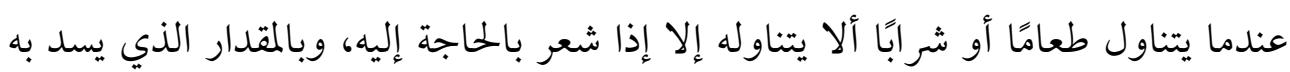

(1) - من توجيهات الإسلام صـ ع 1 وما بعدها بتصرف ، منهج القرآن في بناء المجتمع صـ • ب وما بعدها .

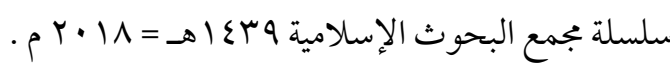

$$
\begin{aligned}
& \text { (Y) - سورة المائدة من الآية (r). } \\
& \text { (r) - سورة المائدة من الآية (•(9). }
\end{aligned}
$$




\section{0}

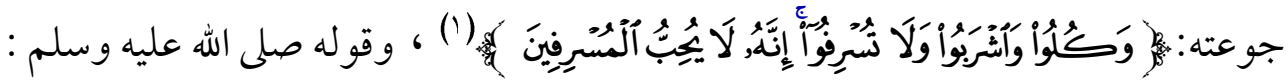

$$
\text { "نحن قوم لا نأكل حتى نجوع وإذا أكلنا لانشبع ". }
$$

ج- ملبس الإنسان : فيحرم على الرجل لبس الحرير وأن ينتتم بالذهب ، ويحرم على المرأة أن

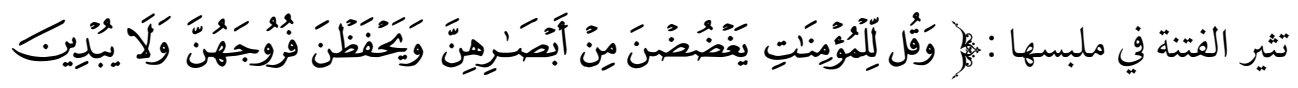

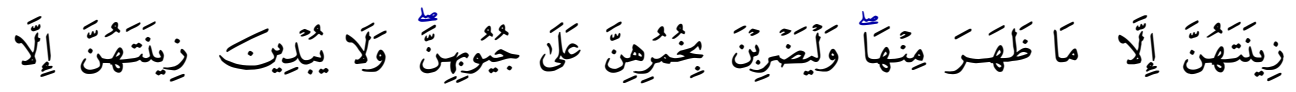

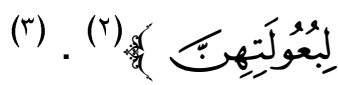

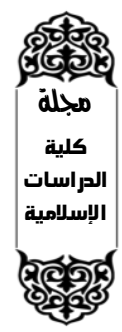

ومنها: الرياضة البدنية، فإنّ ها أثرًا عظيًا في قوة الجمسم ومناعته، وهناك أنواع من الرياضة

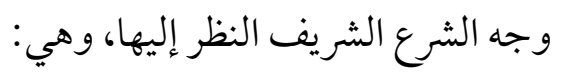

1- الرماية، وبه فسر النبي صلى الله عليه وسلم القوة المأمور بإعدادها في قوله - تعالى - :

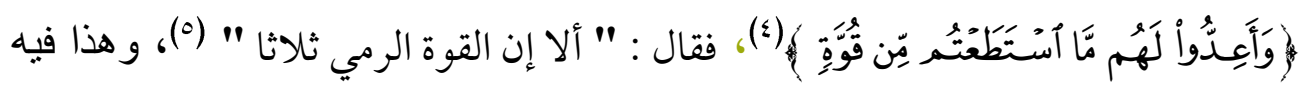
تدريب وترويض للأعضاء الأمر الذي يكسبها قوة ومناعة مقصودأ في نظر الشريعة .

$$
\begin{aligned}
& \text { (1) - سورة الأعراف من الآية (Y). } \\
& \text { (Y) - سورة النور من الآية (IT). }
\end{aligned}
$$

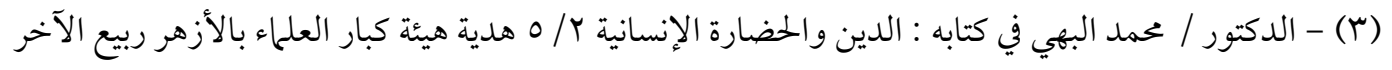

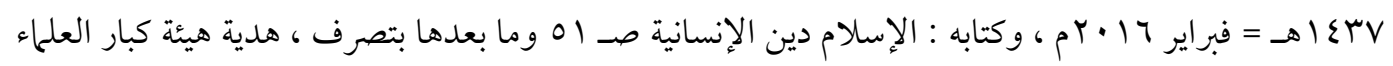

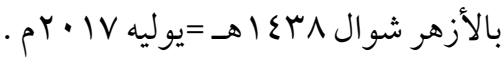

$$
\begin{aligned}
& \text { سورة الأنفال من الآية (•). }
\end{aligned}
$$

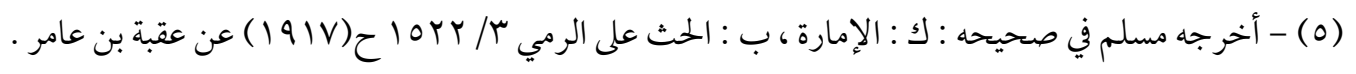

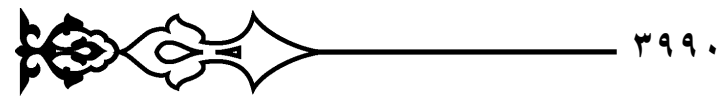


ץ- السباحة، وروي أنّه صلى الله عليه وسلم قال: " حقّ على الوالد أن يعلمه - أي الولد -

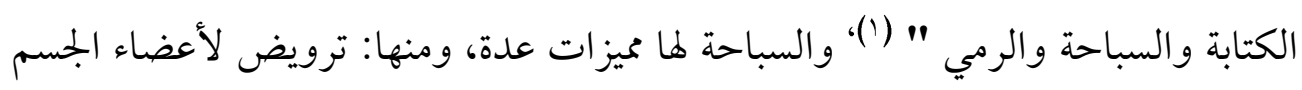
كلّه، فهي تشمل حركة الجسم في الماء والتجديف . ب- العدو " الجري " والمصارعة، فقد ورد أنّ النبي صلى الله عليه وسلم كان يرى أصحابه يتسابقون على الأقدام " الجري " ويقرهم عليه، ومسابقته لعائشة ومسابقة عائشة له صلى الله عليه وسلم ، وروي أنّه صلى الله عليه وسلم صارع رجلا معروفا بالشدة فصرعه النبي صلى الله عليه وسلم ، فقال : عاودني في أخرى ، فصرعه النبي صلى الله عليه وسلم في الثانية ، فقال : عاودني ، فصرعه النبي صلى الله عليه وسلم في الثالثة : فقال الرجل : ماذا أقول لأهلي ؟ شاة أكلها ذئب ، وشاة نشزت ، فحاذا أقول في الثالثة ؟ فقال النبي صلى الله عليه وسلم : ما كنا لنجمع عليك أن نصر عك فنغرمك ، خذ غنمك و انصرف . ع- المبارزة " اللعب بالحراب " ، " الشيش ": فعن أبي هريرة قال: بينما الحبشة يلعبون عند النبي صلى الله عليه وسلم بحرابهم دخل عمر، فأهوى إلى الخصباء، فحصبهم بها ، فقال رسول الله صلى الله عليه وسلم : " دعهم ياعمر " (؟). 0- ركوب الخيل: وقد نوّه القرآن الكريم بالخيل وذكر رباطها في إعداد القوة للجهاد :

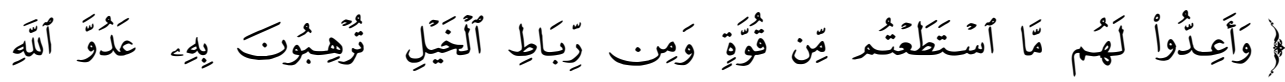

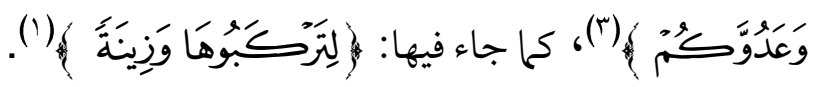

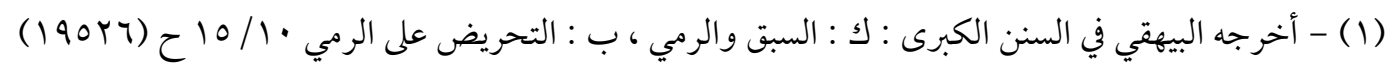

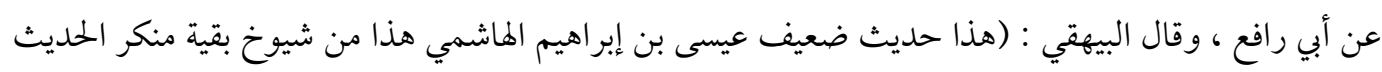
ضعفه يميى بن معين و البخاري وغيرهما ) .

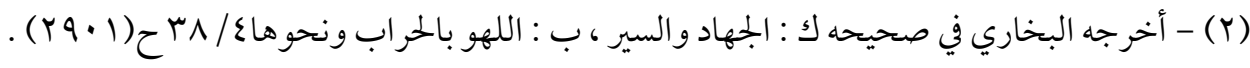

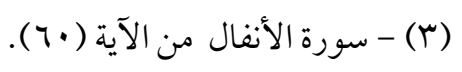




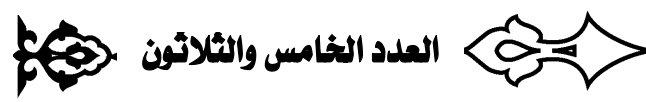

وإذا كانت هذه الآثار النبوية والتعاليم الإسلامية فيها يختص بالرياضة البدنية على سبيل

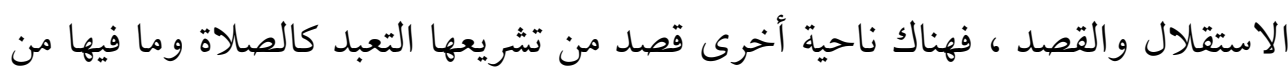
الوقوف التام اتجاه القبلة ورفع اليدين والركوع والسجود والجلوس ، وكلها فيا يرى

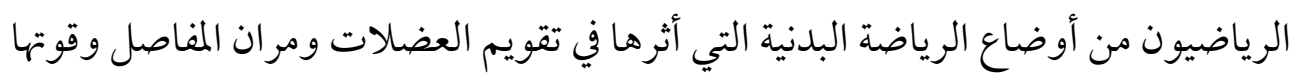

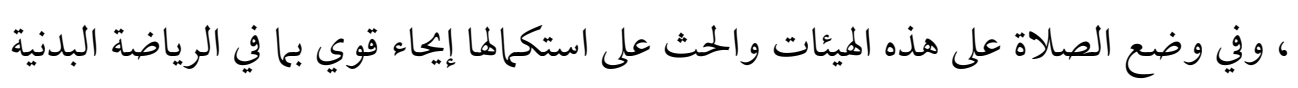

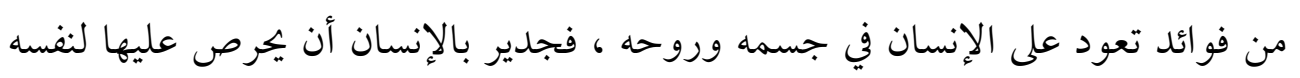

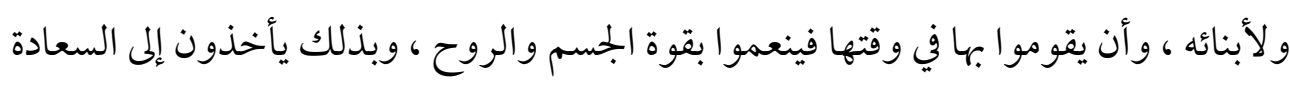

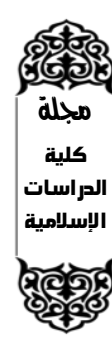

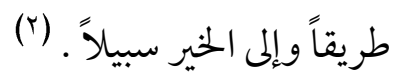

$$
\begin{aligned}
& \text { (1) - سورة النحل من الآية (1). }
\end{aligned}
$$

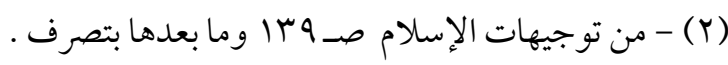




\section{البناي المجتمعي في المنهج القرآني:}

المجتمع هو الأساس الأول الذي تقوم عليه بناء الدولة ، وحين يكون متيناً قوياً سيظل بناء الدولة إلى الأبد ثابتاً شاغخاً ، والأفراد هم اللبنات هذا الأساس فمتى كانت هذه اللبنات

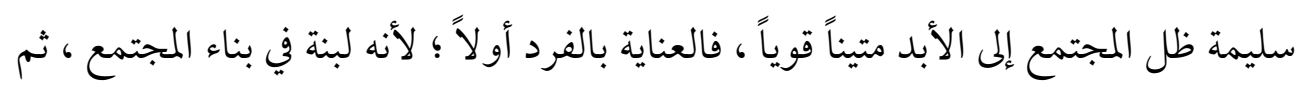
العناية ثانيا بالمجتمع في مجموعة أفر اده وبذلك تتيسر للشعب الدولة الناهضة بالحركة والحياة ، وللناس في ظل المجتمع مناهج في سلوكهم تختلف باختلاف الأفراد تبعا لاستعدادهم النفسي والخلقي والثقافي ، ولإسلام فلسفة في إصلاح المجتمع وتقويمه (') ، وهو ما سيتم توضيحه في المباحث الآتية - إن شاء الله - :

\section{المبحث الأول : الحديث القرآني عن الأسرة :}

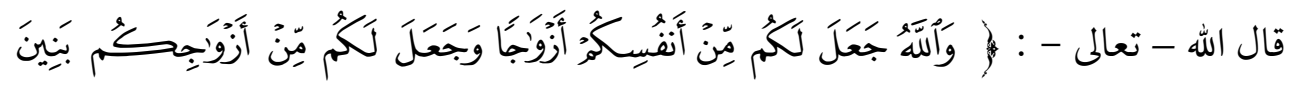

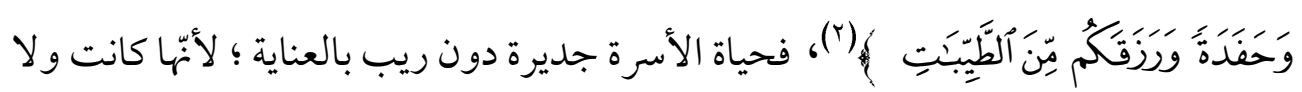
تزال أصلاً في الحياة الإنسانية والاجتماعية ، يتفرع عنه سائر فروع هذه الحياة، ولذلك استهدفت قيام الوحدة الاجتماعية الأولى وهي الأسرة على أفضل الأسس وأقواها من حيث المودة و الحب و التعاطف و البر والتسامح والتعاون ومكارم الأخلاق والآداب . ولتؤدي الأسرة هذه الوظيفة التربوية ينبغي توفّر الشروط التالية: 1 - صلاح مؤسسيها: الزوج والزوجة ومن معهلا.

(1) - نظر ات في الإسلام د/ محمد عبد الله دراز صـ TV ط : المجلس الأعلى للشئون الإسلامية العدد (III ) صفر

$$
\begin{aligned}
& \text {. } \\
& \text { (Y) - سورة النحل من الآية (VY). }
\end{aligned}
$$




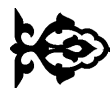

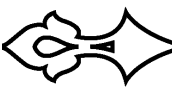

r - اعتمادهما في تربية الأطفال على التربية الإسلامية بدءًا من العقيدة إلى الإعداد للحياة. r - توجيه المجتمع بجموع الأسر إلى اعتماد الإسلام عقيدة ومنهج حياة. ع - تعاون الأسرة مع المؤسسات الأخرى كالمدرسة والجامعة ووسائل الإعلام على تربية النشء. فإذا توافرت هذه الشروط، وتمسك المجتمع المسلم بثوابته من إسلام، ولغة، ومصالح، و أهداف مشتركة، وغيرها، انتتجت الأسر أجيالًا متعاقبة تلتزم بالقيم الإسلامية الثابتة علمًا و تطبيقًا، وتطلب العلم وتتصف بالوعي، فتكون ثابتة متطورة. ولذلك ذكر القرآن الكريم دعائم الأسرة وهي : قوامة الزوج ، وضمان الحقوق العائلية من حيث : أ- الحقوق الزوجية : الحقوق المشتركة - حقوق الزوج - حقوق الزوجة. ب- حقوق الأبوين، والأبناء، والأقارب: برّ الو الدين - حقوق الأبناء - صلة الرحم -

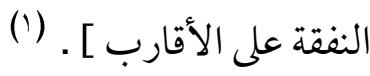
وقد أسبغ القر آن الكريم على الحياة الزوجية معنى جميلا رائعا فيه تكريم لهذه الحياة وتنويه بها

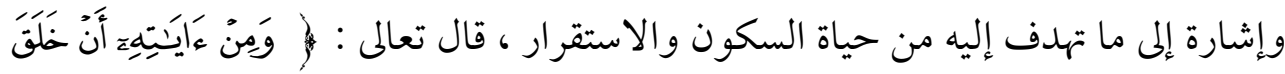

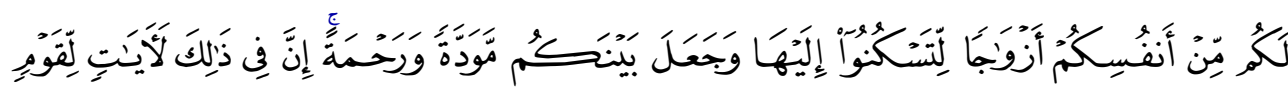

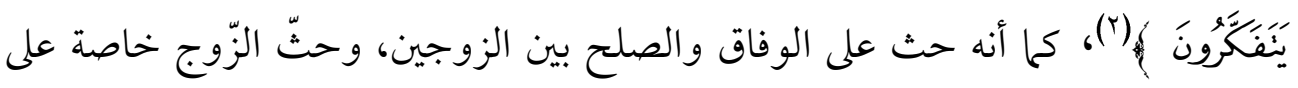
حسن المعاشرة وعدم الاستجابة لعاطفة الكراهية ونزوات النفس ، قال سبحانه : (ُوَكَكَنَّ

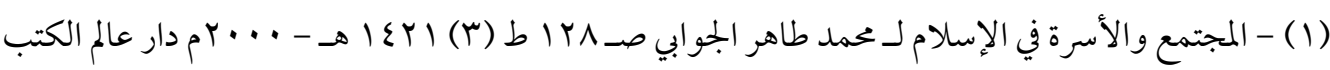
للطباعة .

$$
\text { (Y) - سورة الروم الآية (Y) (Y) - (Y). }
$$




\section{(3)}

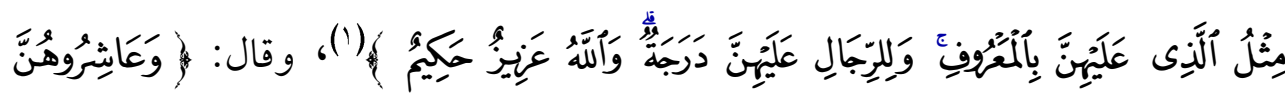

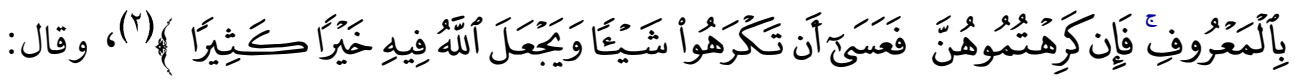

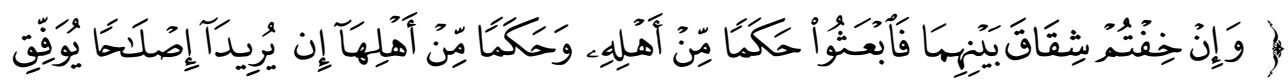

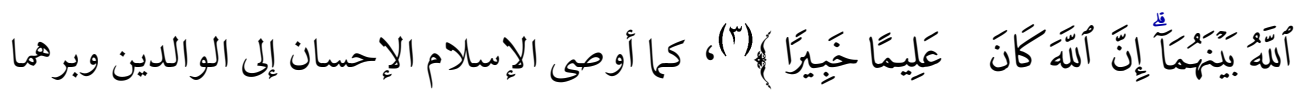

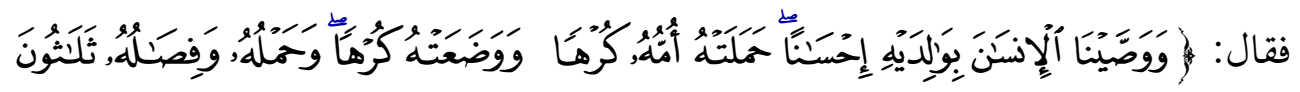

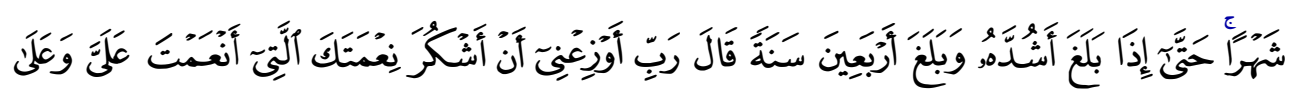

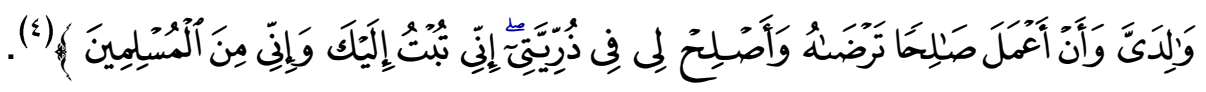
المبحث الثاني: التضامن الاجتماعي في البيان القرآني:

إنّ القرآن من أهدافه الجليلة : قيام مجتمع إسلامي قويّ عزيز متضامن ، يشدّ بعضه بعضًا ، متحدّ في الغايات الكريمة الصالحة التي تتحقق بها سعادته وقوته وكرامته، وقد ورد في هذا

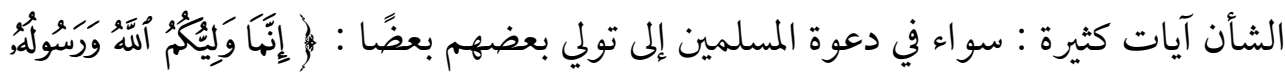

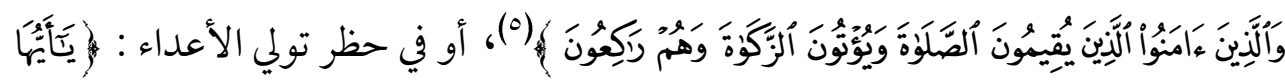

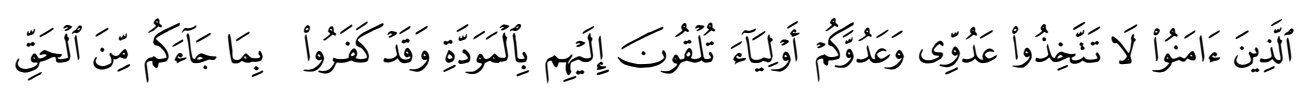

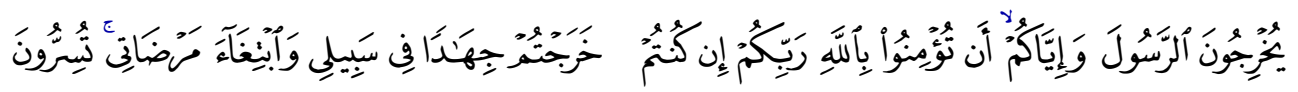

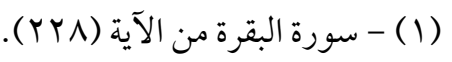

(r)- سورة النساء من الآية (9 (). (r)

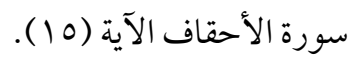

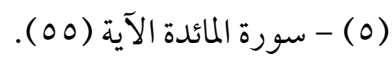




\section{(1)}

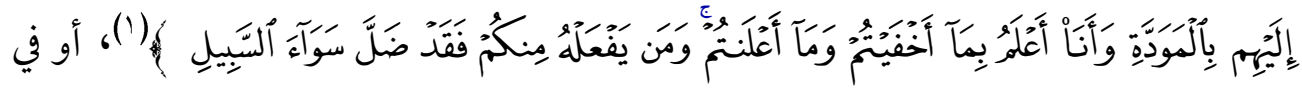

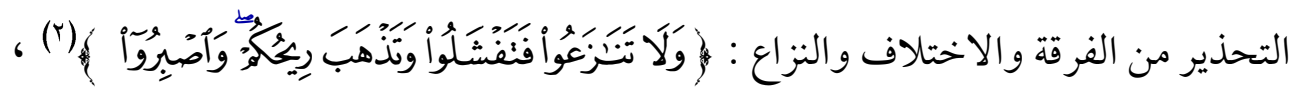

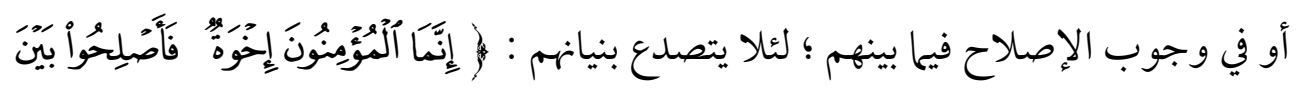

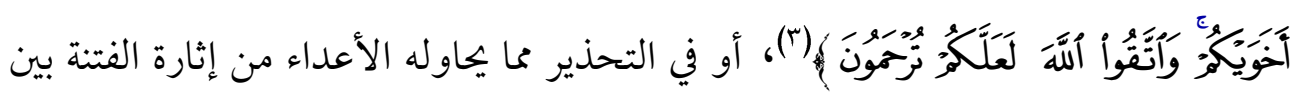

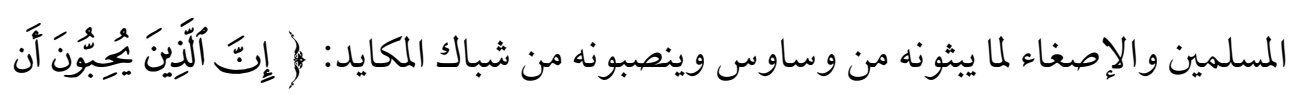

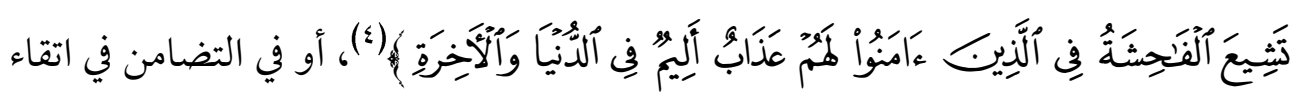

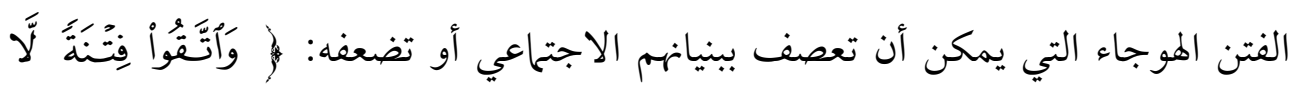

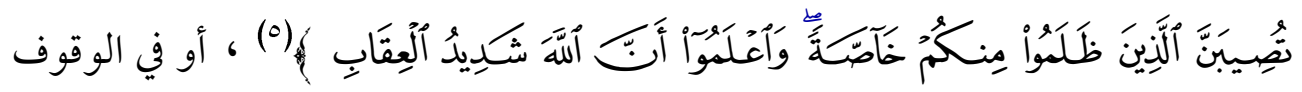

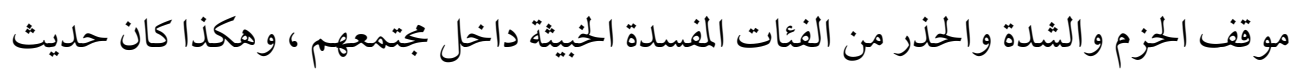

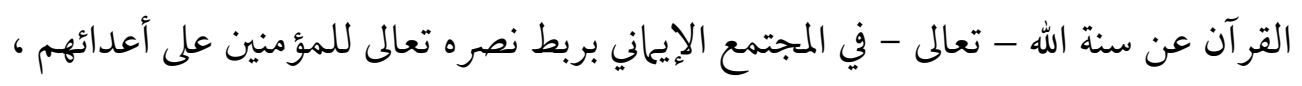

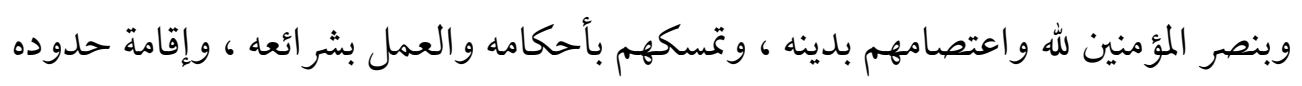

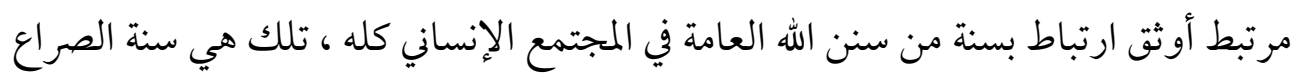

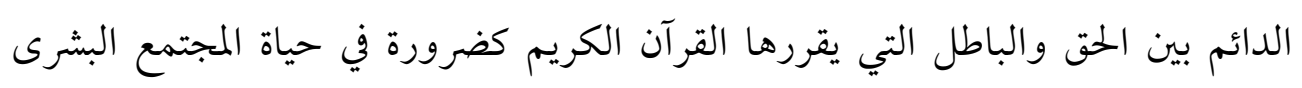

عامة. (")

\begin{tabular}{|c|}
\hline (1) - سورة الممتحنة الآية (1). \\
\hline (ץ) - سورة الأنفال من الآية (؟ع ). \\
\hline (r) - سورة الحجرات الآية (• (1). \\
\hline (ع) - سورة النور من الآية (19). \\
\hline (0) - سورة الأنفال الآية (Yo). \\
\hline
\end{tabular}

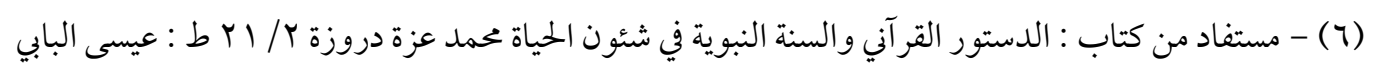

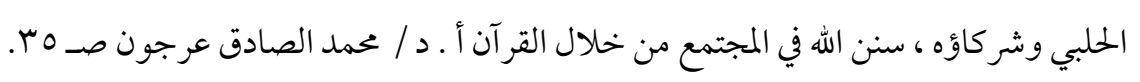
مिن 


\section{المبحث الثالث : المواطنة والعمل المشتزلك :}

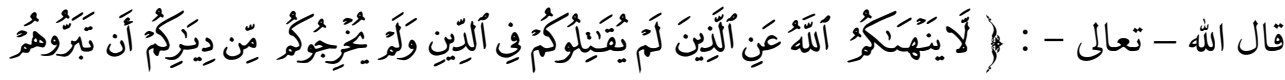

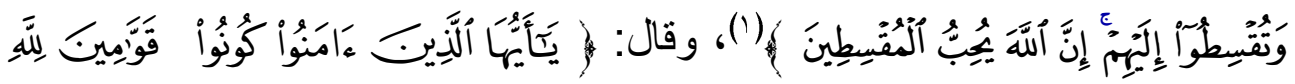

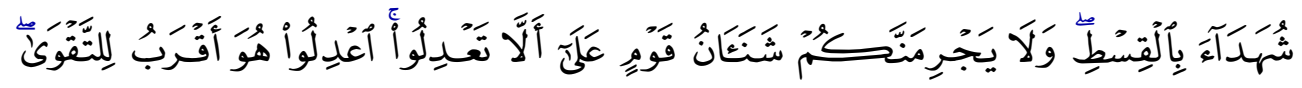

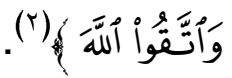

إنّ المو اطنة في الإطار الإسلامي تركن إلى قيم الإسلام التي تحدد الحقوق والواجبات المتبادلة

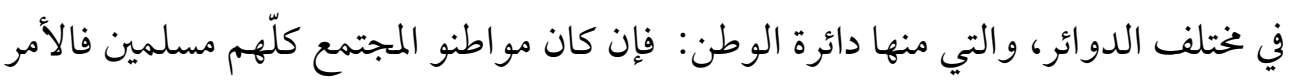
واضح في تساويهم في الحقوق والواجبات المتبادلة بينهم وبين دولتهم، وإن كان في المجتمع غير مسلمين فمن حقّهم التمتع بحقوق المو اطنة ارتكازًا للقيم الإسلامية التي تحمي حرياتهم الدينية ومصالحهم المادية والسياسية دون غبنٍ أو جور ، وقد شهد التاريخ بالموقع المتميز لغير

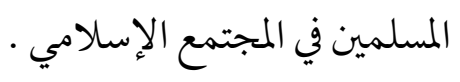
[ و المو اطنة تعني: ا - المساوة بين المو اطنين بصرف النظر عن الاختلاف في الانتحاء أو المذهبي أو الوضع الاجتماعي أو ما شابه ، r- التربية المدنية التي تقوم على تعليم المرء من نعومة أظافره في المدرسة قيم المجتمع الحديث : الولاء ، الانتحاء ، الخدمة العامة ، المشاركة في النشاط الطوعيّ ـ بـ- المشاركة : وتتحقق من خلال المشاركة في شئون المجتمع ، والعمل على النهوض به ، وتحقيق التنمية الحقيقية . ولتفعيل دور المواطنة والعمل المشترك لا بد من عدة أشياء منها : 1 - ضرورة تفعيل النهج المدني والديني في مختلف مكونات المجتمعات ، وترويجه كأداة مهمة في تحقيق المساوة 


\section{5}

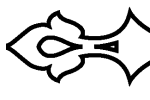

و العدالة الاجتهاعية ، ؟ - إجراء الدراسات الميدانية للتحقق من أفضل السبل الكفيلة بتثبيت مفهوم المواطنة وتطبيقاتها على أرض الواقع ، ب- الإفادة من تأثير الخطاب الديني المتنور والمتقدم والأساليب التعليمية ؛ لتحقيق الإصلاح المطلوب في سبيل المساواة والمواطنة و العدالة الاجتماعية والديموقراطية ، ع - أهمية مفهوم الاعتدال الديني للتأسيس لحالةٍ قوية في مواجهة التطرف الديني والسياسي ] . (') 


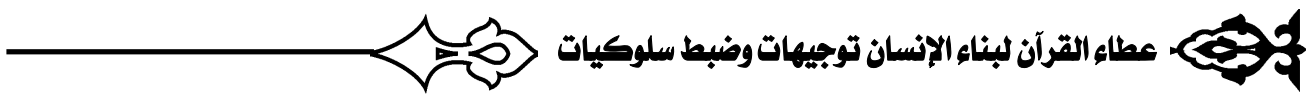

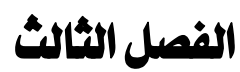

\section{التوجيهات القرآنية في بناء الإنسان عالياً عن طرية العلاقات الدولية:}

النّاس جميعًا ينتهون إلى أصلٍ واحدِ، وإن اختلفو ا أشكالًا و أجناسًا و ألسنةً، وشعوبًا وقبائل،

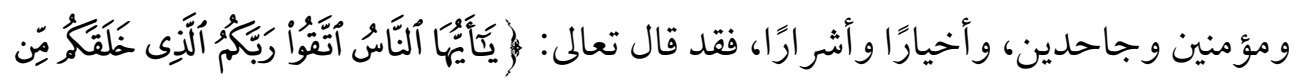

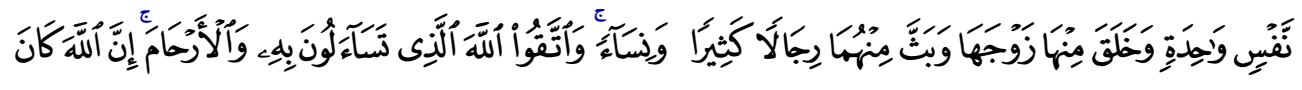

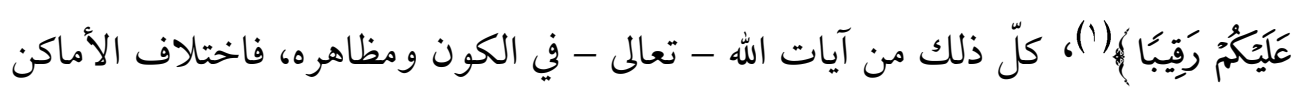
يوجد اختلافًا في الألوان والألسنة، ولذلك ربط سبحانه وتعالى بين اختلاف الألوان

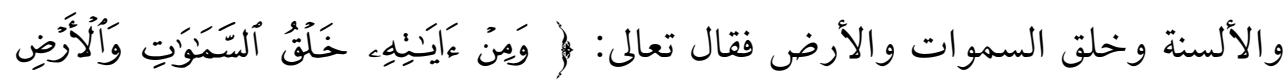

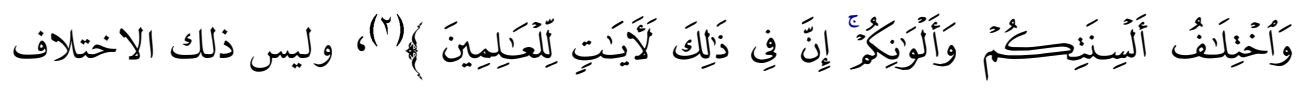

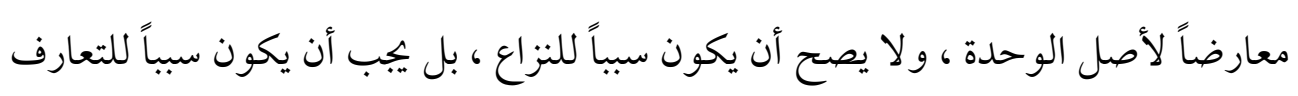

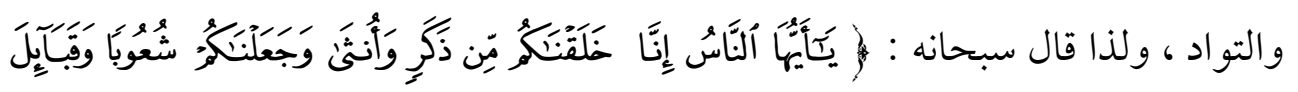

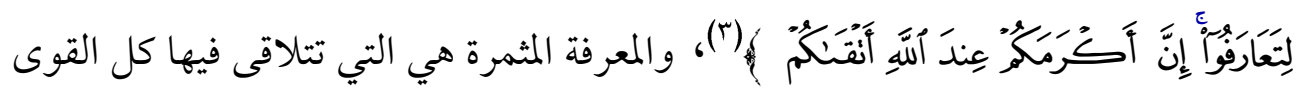
الإنسانية لخير الإنسان بأن يقدم أهل كل إقليم ما عنده من خيرات الأرض وثمر اتها لغيرهم ، وبذلك تتبادل المنافع ويتحقق التعارف الذي أشار إليه النص الكريم ، والإسلام - وهو آخر الأديان السماوية - الذي جاء به محمد صلى الله عليه وسلم خاتم النبيين ، وآخر لبنة في

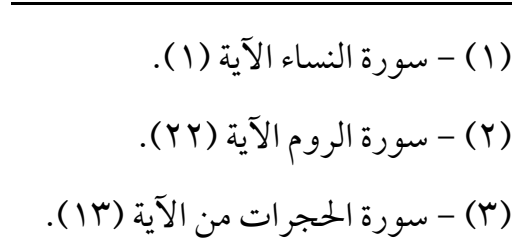




\section{(5)}

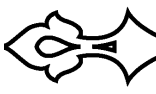

صرح الرسالة الإلهية منظما قواعد العلاقات الإنسانية بين الآحاد والدول على أمثل طريق ،

وجعل أساس العلاقات الدولية التعارف . (1)

\section{المجثث الأول: القرآن الكريم وترسيخ القيم الحضارية:}

تعدُّ القيم في كل مجتمع معايير للسلوك الإنساني ، والمجتمع المتوازن هو : ذلك المجتمع الذي الذي

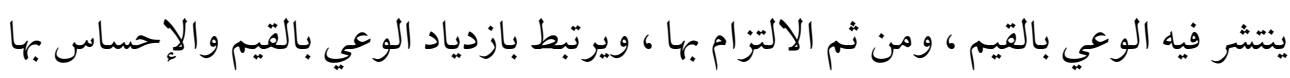

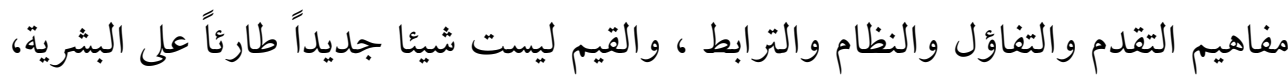
غريبًا على تفكيرها، إنّما هي قديمة قدم الإنسان ذاته، ولكنها لم تتبلور في الأذهان وتتضح

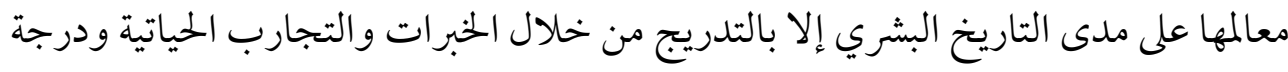
الوعي الفردي والاجتماعي ،ولذلك بيّن القرآن الكريم قو اعد القيم الحضارية ، ويظهر ذلك الك الك

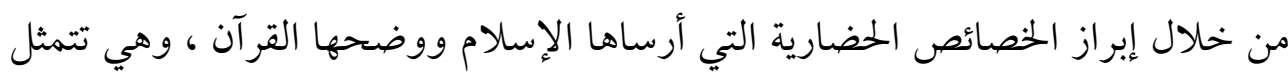
فيا يلي:

أولأ : إنها أول حضارة في التاريخ الإنساني تجمع بين المنقول والمعقول ، فهي ترتبط وتنطلق

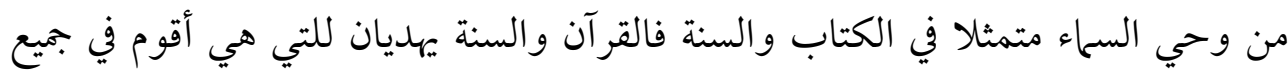

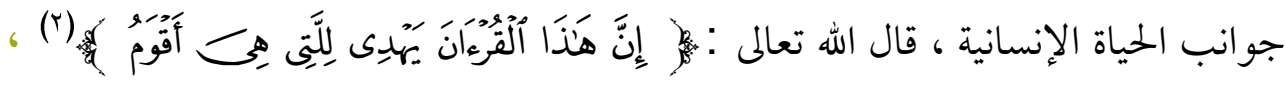

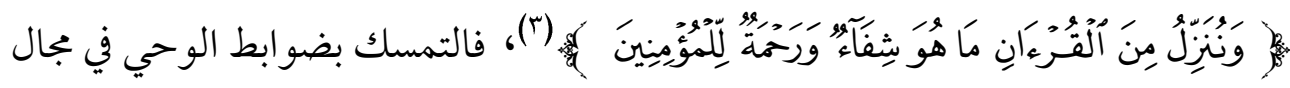

(1) - المختار من العلاقات الدولية في الإسلام للشيخ / عمد أبو زهرة صـ ع وما بعدها بتصرف ـ سلسلة جممع

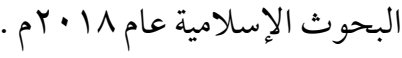

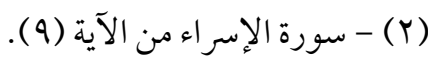

$$
\begin{aligned}
& \text { (Y) - سورة الإسراءمن الآية (Y). }
\end{aligned}
$$

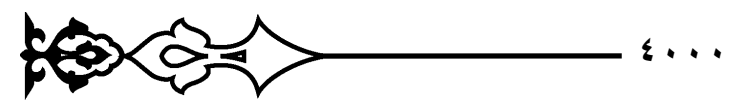


العقيدة والعبادات والأسرة والاقتصاد والسياسة وكل جوانب التشريع يجنّب الإنسان التردي في مهالك الاعتماد على العقل وحده ، أو على الخبرات الإنسانية وحدها . ثُانيًا: إنهّا أول حضارة إنسانية ركزت على عمارة النفس بالإيمان والتقوى، وعمارة الكون باكتشاف السنن الإلهية التي تحكمه، وتوظيفها في كل مجالات التنمية الزراعية والصناعية و العلمية والتكنولو جية وعمارة المجتمعات بتطبيق أحكام الله وهديه. ثالثا: الحضارة الإنسانية أسست المجتمع على التعددية- تعدد الألوان والألسنة والأعراق

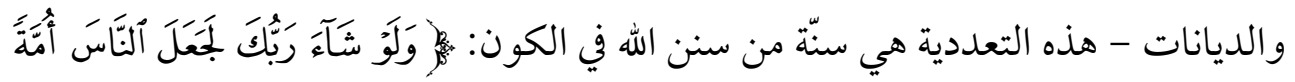

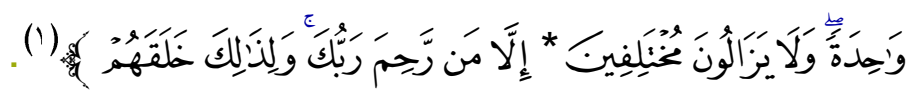

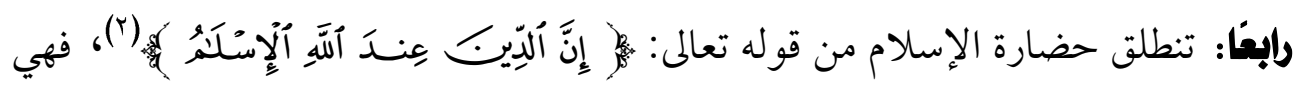
حضارة إيهانية تؤمن بكلّ أنبياء الله ورسله وكتبه، هذا الإيمان شرط أساس لإيهان المسلم،

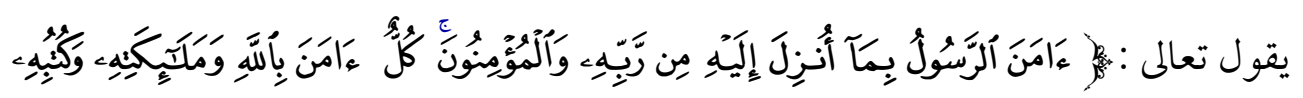

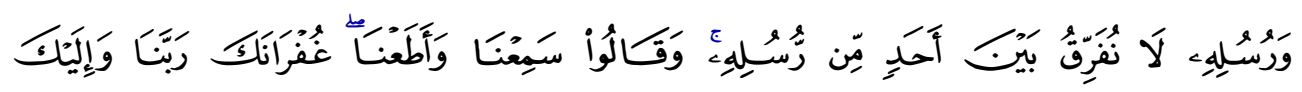

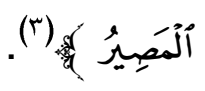
خامسا: الحضارة الإسلامية حضارة أخلاقية، يكفي هنا الإشارة إلى أنّ القرآن الكريم لخص

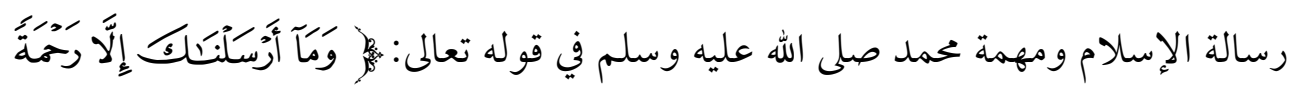

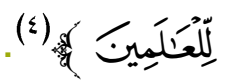

$$
\begin{aligned}
& \text { (1) - سورة هود الآية (11) (1) (1). } \\
& \text { (Y) - سورة آل عمر ان الآية (19). }
\end{aligned}
$$

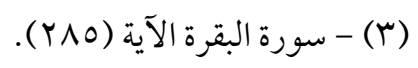

$$
\begin{aligned}
& \text { (ع) - سورة الأنبياء من الآية (V) (l). }
\end{aligned}
$$$$
\text { \&.. }
$$ 


\section{F)}

سادسا: حضارة الإسلام تقوم على الوسطية والاعتدال في كل شيء " عقيدةً وشريعةً

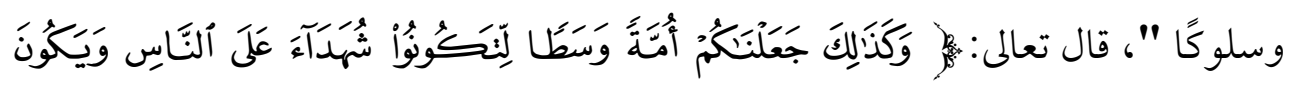

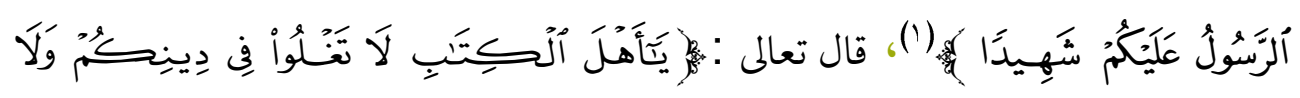

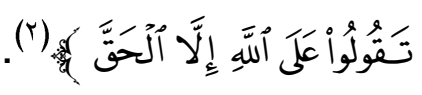
سابغا: الحضارة الإسلامية تعلي من قيمة العقل، فالتفكير في الإسلام فريضة إسلامية،

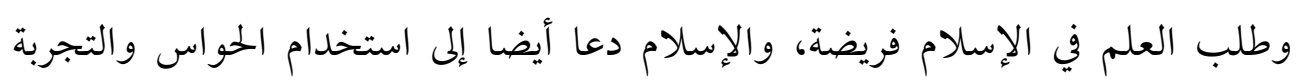

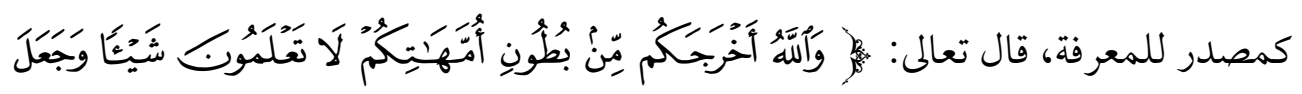

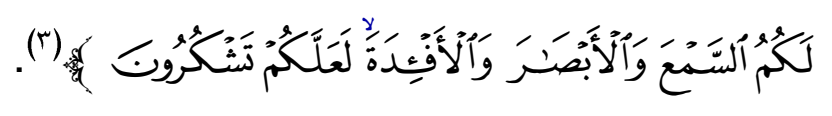

ثامنا: حضارة الإسلام تقوم على إطلاق الإبداع العلمي في فهم الكون والإنسان والبيئة

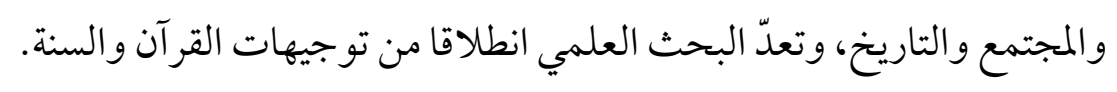
تاسعا: حضارة الإسلام تحض الإنسان والجماعة المسلمة على بناء أقصى قدر مككن من القوة

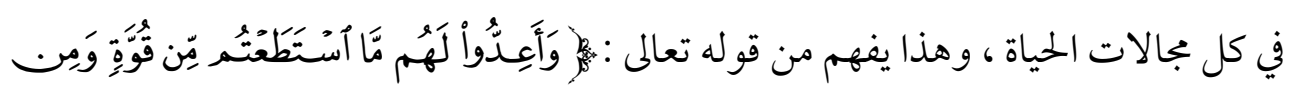

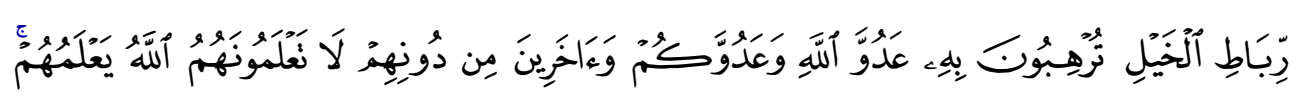

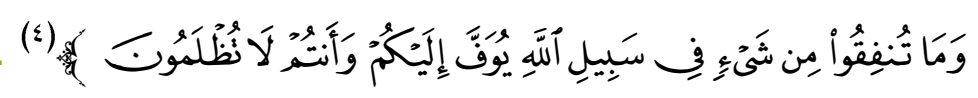
عاشراً: حضارة الإسلام ترتكز على العدل المطلق دون تميّز، ومن هذه الآيات قوله تعالى :

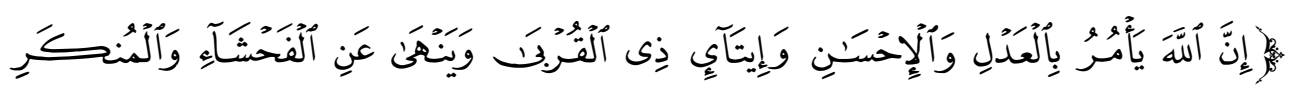

$$
\begin{aligned}
& \text { (1) - سورة البقرة من الآية (r؟ ( ) ). }
\end{aligned}
$$

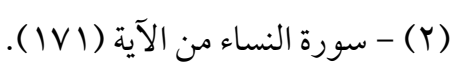

$$
\begin{aligned}
& \text { (Y) - سورة النحل الآية (YN). }
\end{aligned}
$$

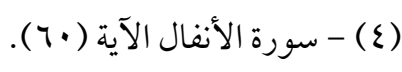

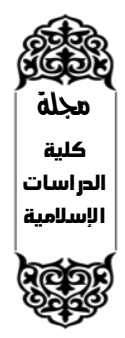




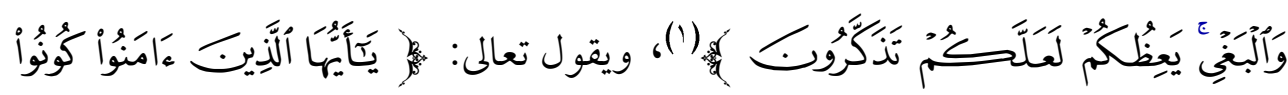

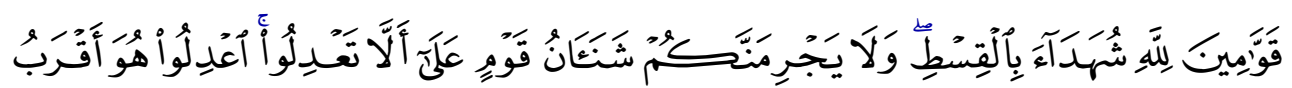

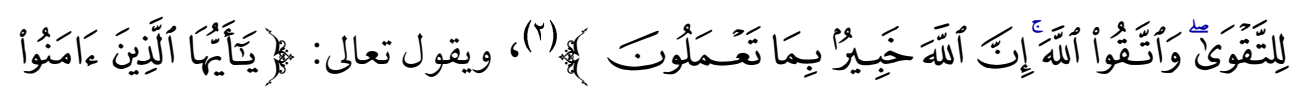

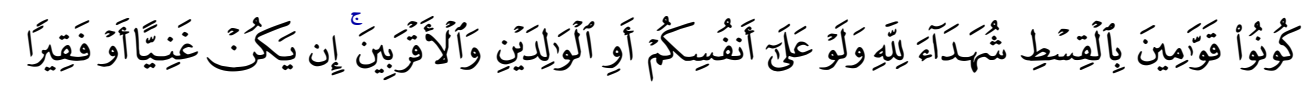

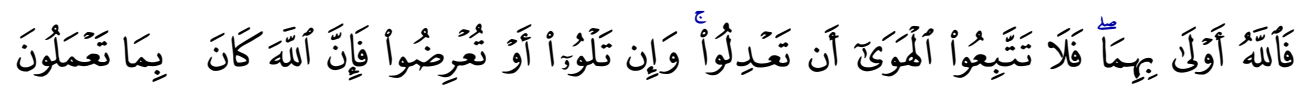

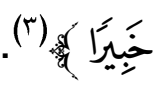

حادي عشر: من أسس الحضارة الإسلامية إطلاق الحريات لكل الناس وفي كل الميادين بشرط البعد عن التطرف والغلو أو الإفساد والفساد، وفي مقدمة الحريات : حرية العقيدة

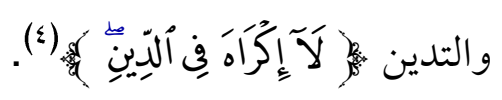
ثاني عشر: تؤكد الحضارة الإسلامية على تنمية ثقافة الشعور بالمسئولية، من ذلك قوله تعالى:

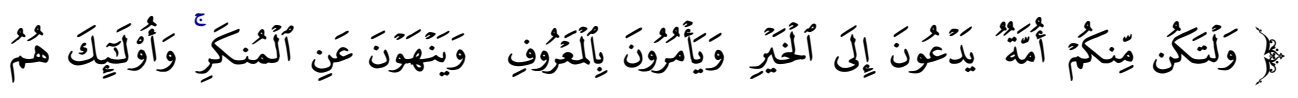

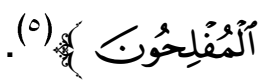
ثالث عشر: ترسي الحضارة الإسلامية ثقافة السلام والتعايش السلمي بين المسلمين وبين غير المسلمين الذين يعيشون داخل المجتمع المسلم.

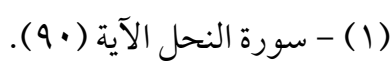

(Y) - سورة المائدة الآية (N).

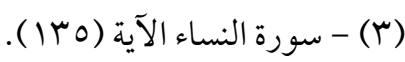

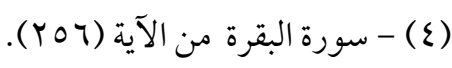

(0) - سورة آل عمر ان الآية (ع • (1).
}

$\leq \ldots$ 


\section{0}

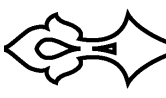

رابع عشر: ترسي الحضارة الإسلامية من قدرات الإنسان وجهده وإرادته نحو التغير

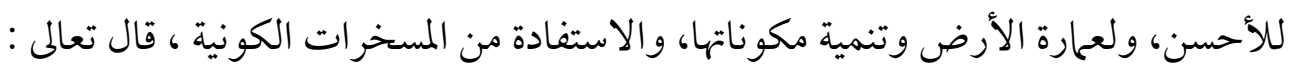

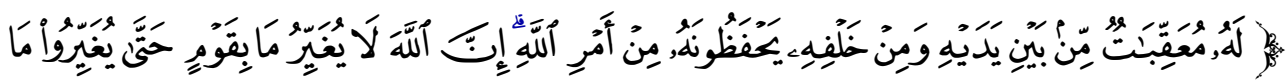

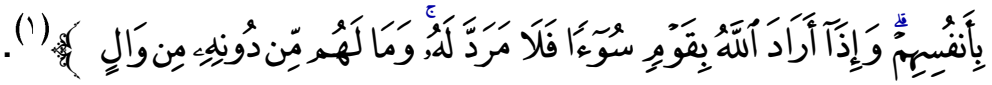
خامس عشر: ترتكز الحضارة الإسلامية تركيزًا خاصًّا ونوعيا على الأهمية المحورية لمؤسسة

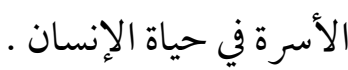

سادس عشر: انطلقت الحضارة الإسلامية من أنّ الأمن النفسي والاجتماعي، المادي

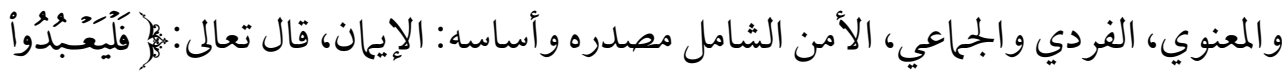

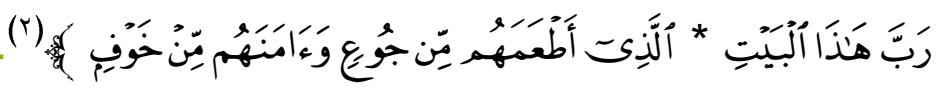
سابع عشر: حضارة الإسلام تملك ذاتيًا آليات البقاء والاستمرار رغم تبدل العصور والأزمان، ورغم ظهور مستندات حضارية جديدة باستمرار .

هذه أبرز معالم وأهداف وقيم الحضارة التي أرسى الإسلام دعائمها ، والتي بدأت مع نزول

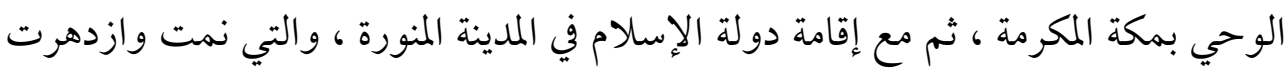

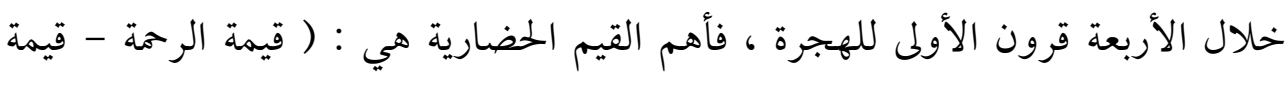

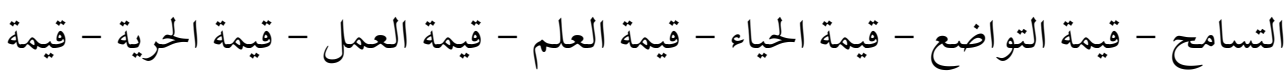

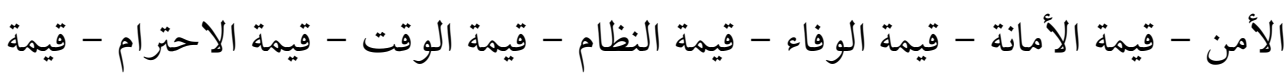

$$
\text { (Y) - سورة الرعد الآية (1) - (1). }
$$




\section{3}

عطاء القرآن لبناء الإنسان توجيهات وضبط سلوكيات

التعاون - قيمة النظافة - قيمة الصداقة - قيمة الشكر - قيمة الانتماء - قيمة التدين - قيمة

الوعي بالسنن الكونية - قيمة البشاشة - قيمة الأمل - قيمة الترويح عن النفس ) . (1)

\section{المبحث الثاني: القرآن الكريم وتوثية العلاقات الدولية والتعايش السلمي، وفيه}

\section{المطلب الأول: قواعد العلاقات الدولية في الشريعة الإسلامية:}

إنّ الأصل في العلاقات الإنسانية هو : التعاون والتعارف المبنيّان على وحدة البشر ( العائلة الإنسانية ) الأمر الذي يؤدي إلى احترام الكرامة الإنسانية، وحرية العقيدة والعبادة، وأنّه لا يجبر أحد على الدخول في الدين، ولا يحاسب المرء إلا على أعماله الظاهرة الناتجة عن جوارحه التي يترتب عليه إحداث ضرر بالغير، وبالتالي فالمسلم مطالب بتحقيق العدالة والمساواة بين المسلمين وغير المسلمين، كما أنّه مطالب بالسماحة وحسن الخلقق حتى يقوم ببناء الحضارة وصناعة الفكر، وعالمية الرسالة، ونشر الدعوة إلى الله - تعالى - بالحكمة والموعظة الحسنة . ونودّ أن نبدأ هنا بالقيم الإنسانية في الحروب الإسلامية، فـ [إذا كانت الحروب الإسلامية تنفرد بغايتها المقدسة وهي الجهاد في سبيل الله، أي: في سبيل الحق والعدل والحرية والفضيلة و الكرامة والعزة، فإنها - أيضا- تنفرد بقيم إنسانية لم تعرفها البشرية في تاريخها الطويل، وهذه القيم تمثل ضو ابط أخلاقية وقو اعد ملزمة في السلم والحرب، و أهمها:

(1)- العطاء الإسلامي للحضارة الإنسانية أ .د/ نبيل السمالوطي صـ عَ وما بعدها بتصرف واختصار ط ( 1 (1) رابطة الجامعات الإسلامية : سلسلة الدراسات الحضارية العدد الثالث عام الباع اهـ = · · · بم ، الإنسان والقيم

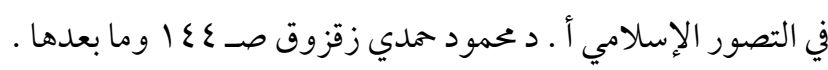
$\varepsilon \cdot \bullet$ 


\section{0}

العدد الخامس والثلاثقرن

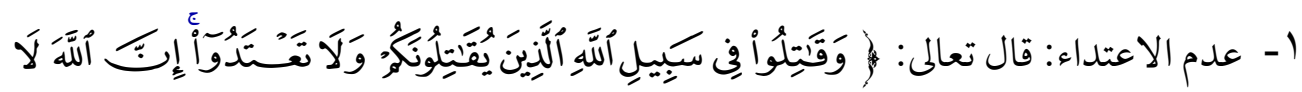

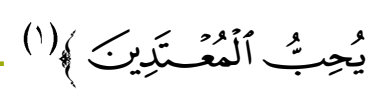

r- وجوب الإعلان: إنّ علاقة المسلمين بغيرهم إمّا أن تحكمها عهود ومواثيق، وإمّا ألا

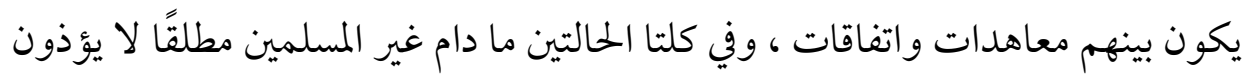

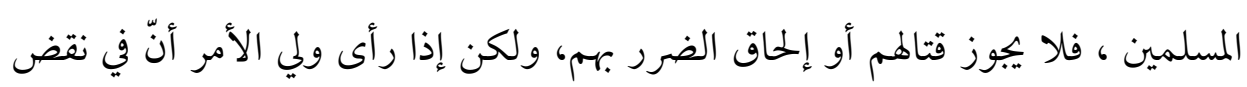

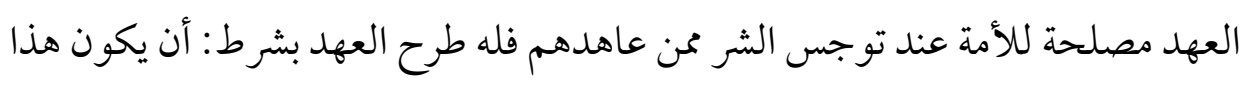

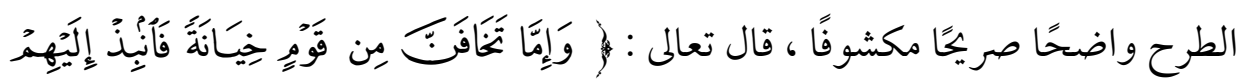

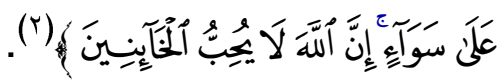

ك- التخيير بين ثلاث خصال : عن سليان بن بريدة عن أبيه قال : كان رسول الله صلى الله

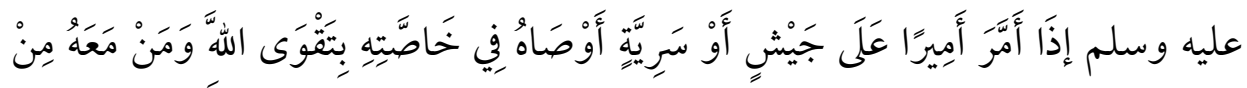

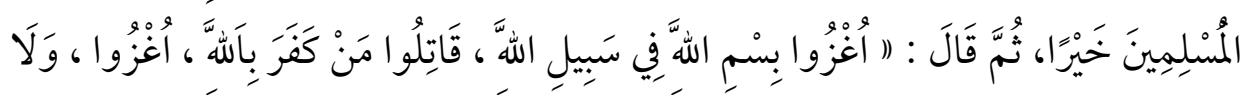

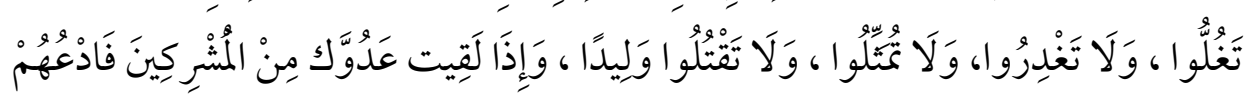

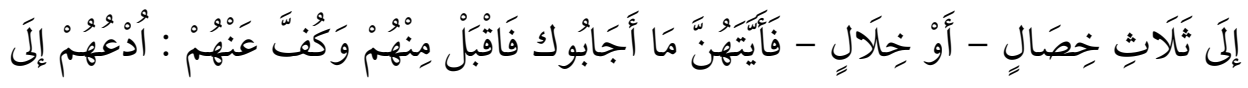

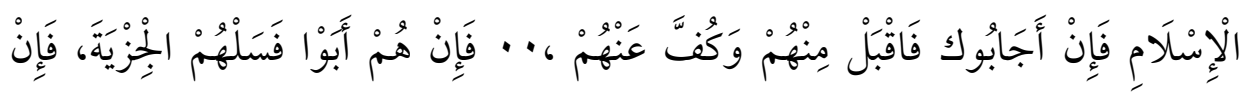

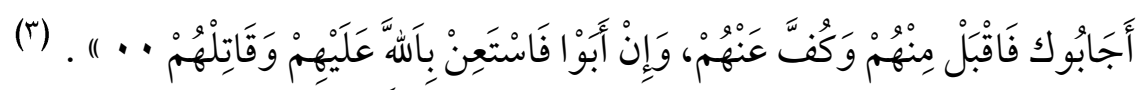

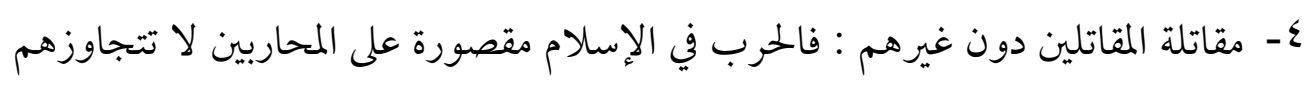

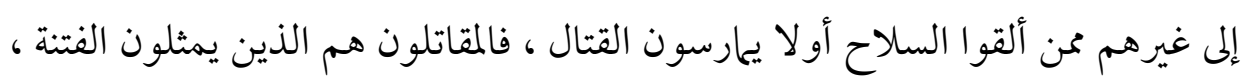

(1) - (1) - مورة البقرة الآية (·1) - (19).

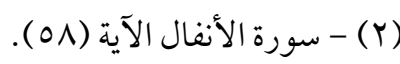

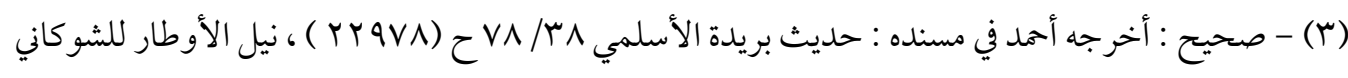

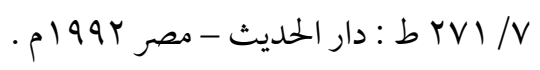

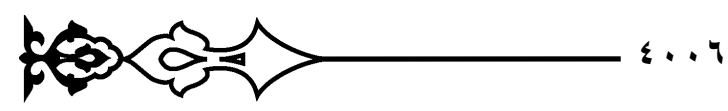




\section{3}

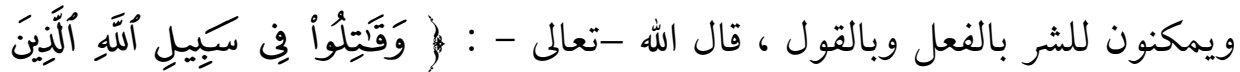

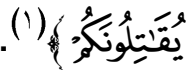

0- عصمة دماء غير المقاتلين: وقد وردت كثير من الأحاديث والآثار التي تنهي عن قتال

ا - التعاون الإنساني، والذي أساسه التعاون على البّر وماية الفضيلة، ومنع الأذى؛ لأنّ فيه

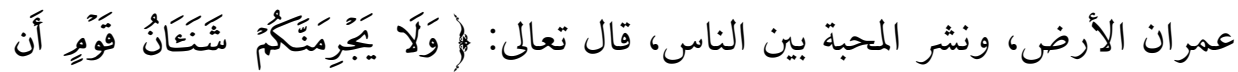

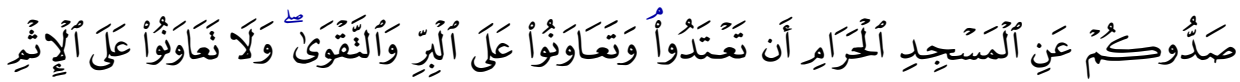

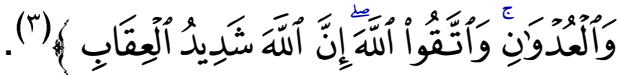

Y- الكرامة الإنسانية: والكرامة التي يتم تقريرها للشخصية الإنسانية، ليست كرامة مفردة ولكنها كرامة مثلثة: كرامة هي عصمة وحماية ، وكرامة هي عزة وسيادة ، وكرامة هي

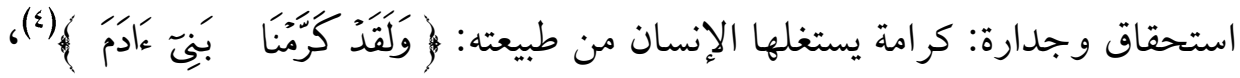

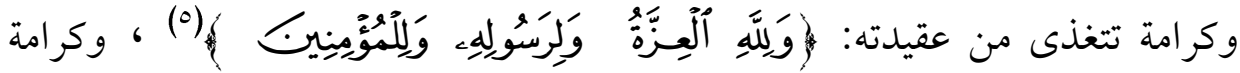

$$
\text { (1) - (1) - سورة البقرة من الآية (19) (19). }
$$

(Y) - نحو رؤية إسلامية في القانون الدولي الإنساني أ ـ د / عمد الدسوقي صـــه وما بعدها بتصرف : المجلس

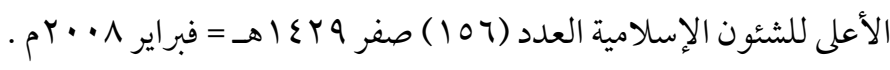

$$
\begin{aligned}
& \text { (r) - سورة المائدة من الآية (r). } \\
& \text { (ع) - سورة الإسراء من الآية (•V). } \\
& \text { (0) - سورة المنافقون من الآية (1). }
\end{aligned}
$$

$\varepsilon \cdots v$

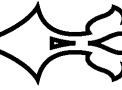




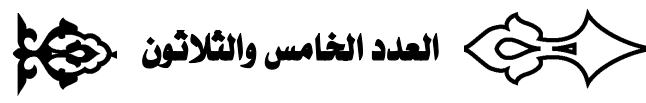

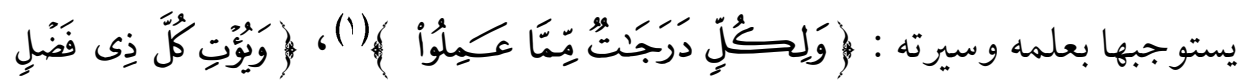

\section{فَضَْلَهُ (r)}

ז- الوفاء بالعهد: فالطريقة المثلي لاستقرار السلامة، وجعل التعارف على أساس سليم هو

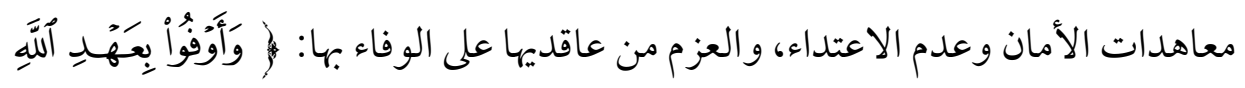

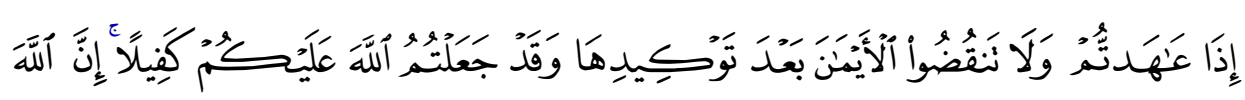

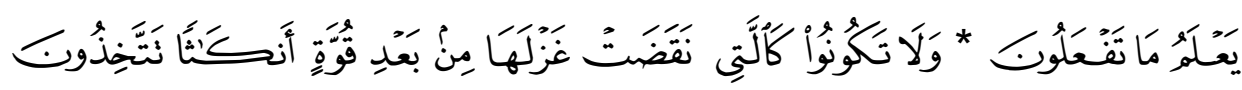

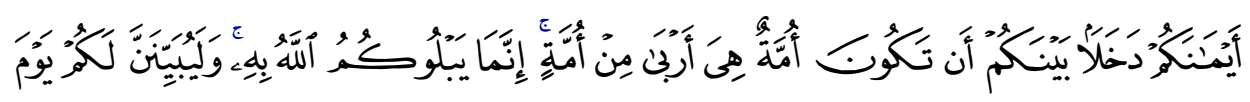

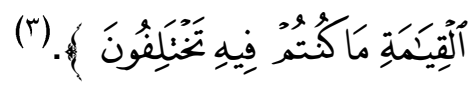

ـ - العدالة والفضيلة والحرية: فهذه الأمور ميز ان العلاقات الإنسانية في كلّ أحو الها في حالة

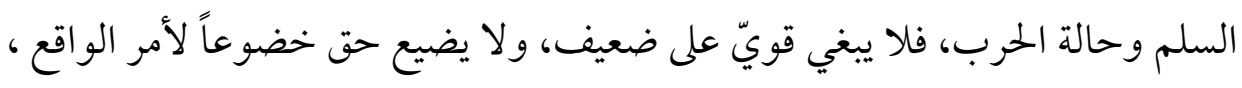

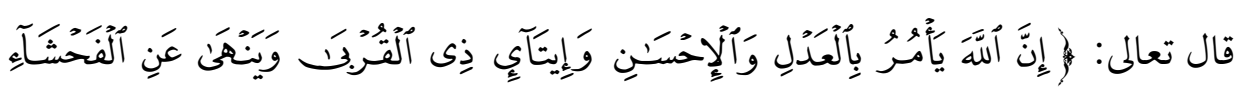

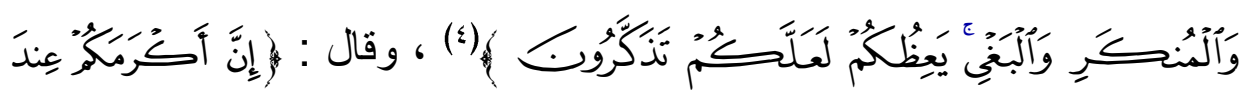

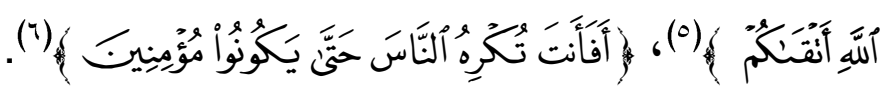

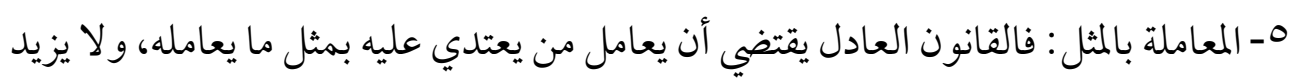

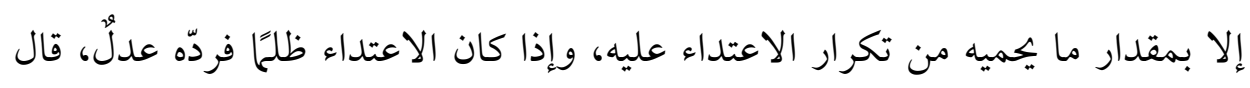

$$
\begin{aligned}
& \text { (1) - سورة الأنعام من الآية (rسו). } \\
& \text { (Y) - سورة هود من الآية (r). } \\
& \text { (r) - سورة النحل الآية (1)-9r). } \\
& \text { ( ) - السورة السابقة الآية ( • ). } \\
& \text { (0) - سورة الحجرات من الآية (r) (I). } \\
& \text { (7) - سورة يونس من الآية (99). }
\end{aligned}
$$




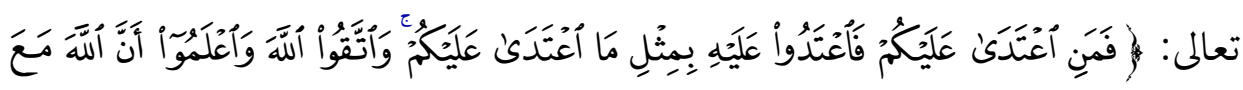

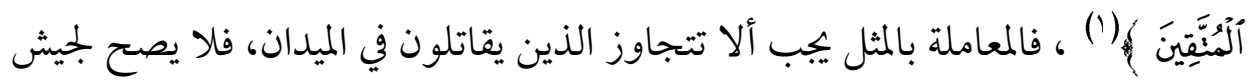

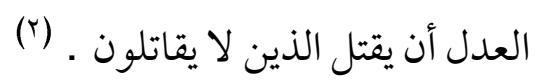

\section{المطلب الثاني: القرآن والتعايش السلمي بين بني الإنسان:}

إنّ التعايش السلمي منهجُ قرآنيّ ، وهدي نبويّ ، وضرورة بشريّة ، وحاجة إنسانيّة ، فالإسلام لا يعرف الانغلاق والتحجر ولا الانخراط ونسيان الذات، فكلا الأمرين ذميم، ولمّا كانت رسالة الإسلام عالمية، وأنّ من مقاصدها تحقيق العدل والمساواة والتعاون و التعارف، وأنّ الأصل في الإسلام السلام، وتأمين الناس على أرواحهم وأمو الهم تراه يسعى

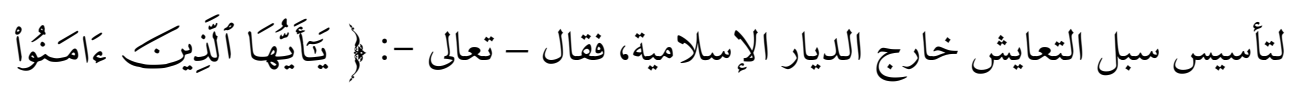

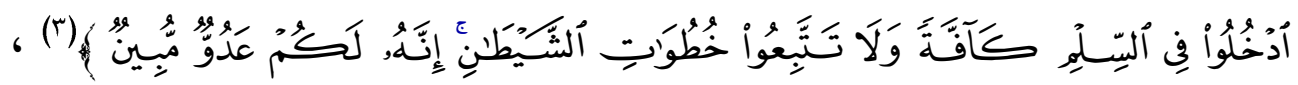
و انطلاقا من هذه القاعدة فإنه يوضح أنه لا اعتداء ولا بغي ، وأن واجب العدل والإقساط من المسلمين تجاه غير المسلمين لا ينتفي حتى في حالة الحرب ؛ لأن الحرب والقتال في المفهوم الإسلامي إنما هو حالة طارئة يضطر فيها المسلمون لحمل السلاح واستخدامه للدفاع عن

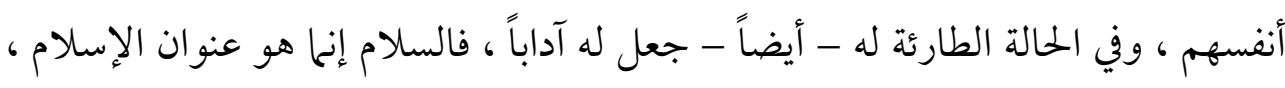

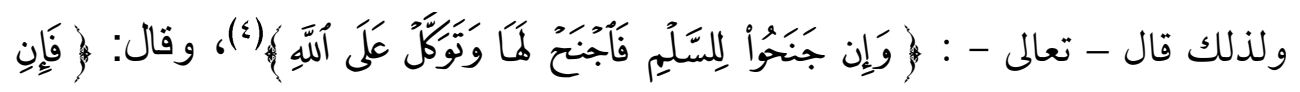

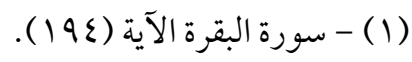

(Y) - المختار من العلاقات الدولية في الإسلام للشيخ أبو زهرة صـ • ا وما بعدها بتصرف ، نظرات في الإسلام صـ

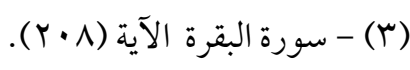

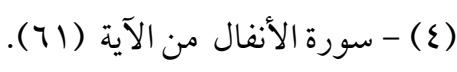

$\{\ldots$

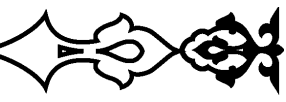




\section{0}

العدد الخامس والثلاثون

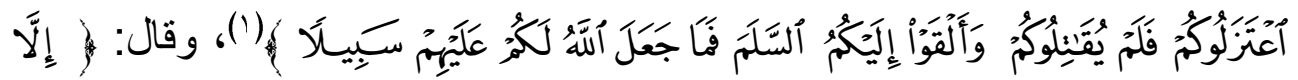

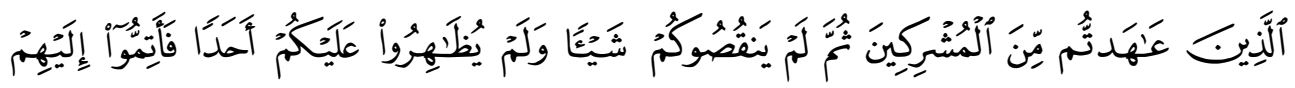

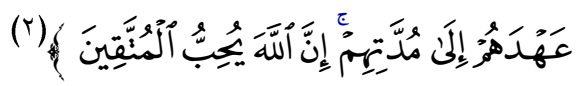

من أهم الأمور التي تساعد على تفعيل دور التعايش السلمي:

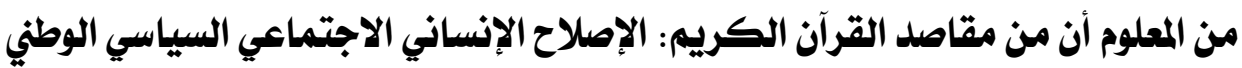

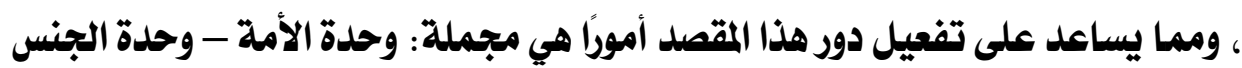
البشري - وحدة الدين - وحدة التشريع بالمساواة في العدل - وحدة الأخوة الروحية بالمساواة في التعبد - وحدة الجنسية السياسية الدولية - وحدة القضاي - وحدة اللغة. (־) فهذه أمور إذا تمّ وضعها في الاعتبار، والاعتناء بها، والوثوق بتطبيقها، فإنبها ستكون جديرة بتحقيق مبدأ التعايش السلمي الذي نبه إليه الإسلام، وعوّل عليه القرآن . كما أنّ هناك أمورًا مساعدة على تفعيل هذا الدور، وهي: أولأ: الاحترام المتبادل: وذلك عن طريق التبادل التجاري، والعلاقات الاقتصادية، والمشاريع الاستثمارية، وهي دليل على قوة الروابط الاجتماعية الذي يعرف حاليًا بالتعايش الاجتماعي، فالتاجر يعرف بسلوكه وسمعته الطيبة وحسن خلقه وطيب كلامه، وكلّ ما يصدر عنه من فعل أو قول فهو يعكس ارتباطه بمعتقداته .

ثُانيا: العامل الثقافي: فالثقافة هي المستودع الكبير به عدة أشياء غختلفة، منها: المعارف المتنوعة، والمعتقدات السائدة، والقيم الأصيلة، والفنون الجميلة، وأساليب حفظ البقاء التي اكتشفها أو استعارها أو أوجدها الإنسان .

$$
\begin{aligned}
& \text { (1) - سورة النساء من الآية (•9). } \\
& \text { (Y) - سورة التوبة الآية (ع). }
\end{aligned}
$$

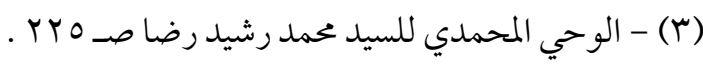$$
\text { क्षे }
$$ 


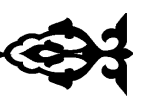

ثالثها: القوة والثقة بالنفس: فإذا كانت الحكمة تقول: " الصالحون يبنون أنفسهم ، و المصلحون يبنون الأمم "، أي: إذا كان الصالحون يبنون أنفسهم، وهو أمر جيد بلا شك، فإنّ الأمم و الشعوب تحتاج إلى المصلحين الذين يبنون الأمم على اختلاف جنسياتهم وألو انهم ومعتقداتهم، ويسعون بهم إلى الارتقاء نحو الخير والفضيلة، ويقومون بدور فعال في نشر ثقافة التعايش السلمي بين الشعوب، فإنّ إصلاح الأحوال والعلاقات يهتاج إلى وقفة لمصارحة النفس، ومعالجة حالات الإنسان وتقلبات نفسه ، حتى ما يشعر المرء بأخيه الإنسان، ويسعى في إسعاده والمجاهدة في خدمته، فلا بد وأن يكون بهذا الإنسان القوة والثقة بالنفس ما يجعله صادقاً مع نفسه وإخوته في الإنسانية، وتحت مراقبة ربانية من الله - تعالى -؛ لينعم بذلك هو وسائر البشر بالأمن والأمان وبتعايش سلمي وسلام وإسلام . 


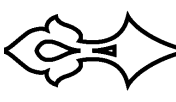

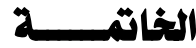

الحمد لله والصلاة والسلام على رسول الله محمد وعلى آله وصحبه ومن والاه ، وبعد : فهذه الجولة السريعة في رياض القرآن الكريم الذي لا يزال بكرًا لم يفض، بحرًا لا ينضب،

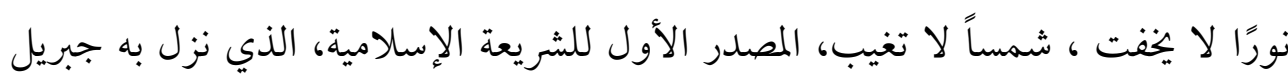

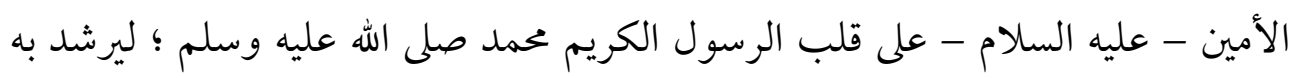

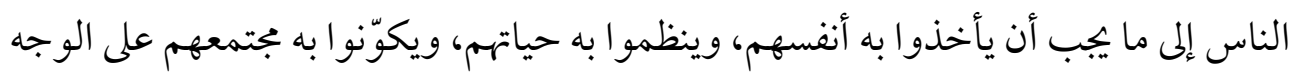
الذي يسعدهم في الدنيا بالعزة والسلطان والتمكين، وفي الآخرة بالرحمة الدائمة وبالنعيم

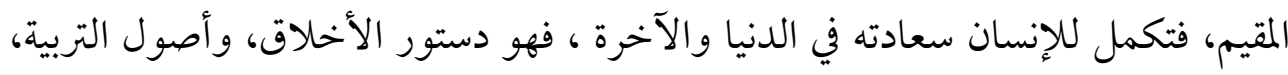

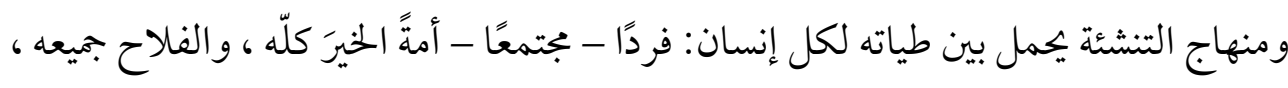
واستقامة السلوك ، والبصر الواعي ، نراه اهتم بالعهارة والبناء ، وخاصة بناء الإنسان،

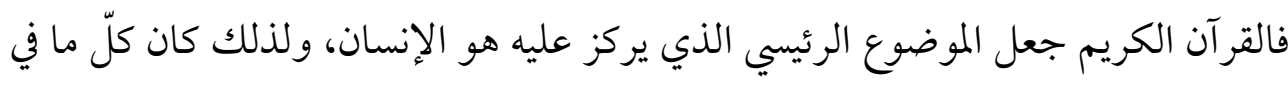

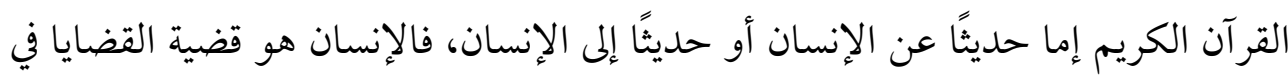

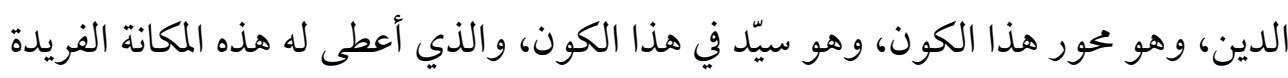

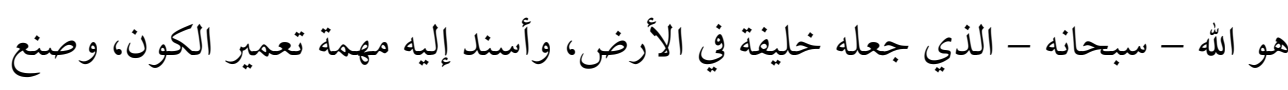
الحضارة فيه، وقد تنوّع هذا البناء، فهناك بناء عام عن طريق التربية وغرس العقيدة والقيم

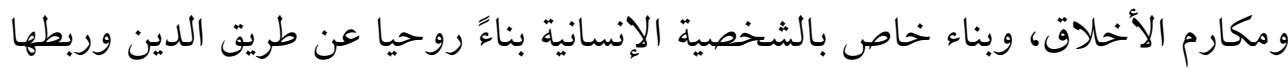

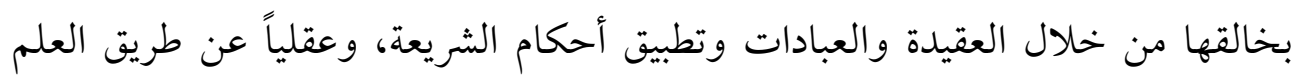
والمعرفة والاستفادة من الوظائف التربوية للعقل ، وجسدا عن طريق المحافظة على الصحة بالنظافة والرياضة ، والبعد عن كل ما يؤي الجسد ، بناء الإنسان بجتمعيا عن طريق روابط

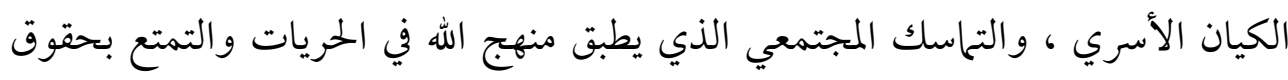

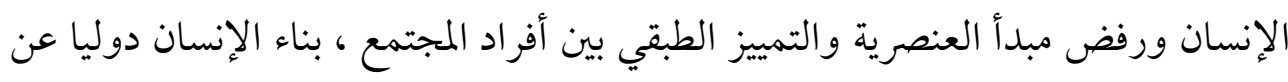


طريق ترسيخ القيم الحضارية التي تحفظ للإنسان كرامته المكفولة له من قِبل الشارع الحكيم، وتوفر له الرقي و التقدم والحضارة وصناعة التاريخ ، وأيضا القواعد التي تحكم فكر وسلوك وعلاقات الناس في الدول، وتدعوهم إلى إعلاء وإفشاء قيم الأمن والسلام والتعايش

وهكذا وجدنا القر آن الكريم قد سما بالإنسانية عن أن يكون اجتماعها وتر ابطها مستمدًا من أوضاع بشرية يغلب عليها العنصرية والعصبية الأمر الذي يدفع بهم إلى التفرق والخصام ، وتنتشر بينهم العداوة والبغضاء، فتتقطع الروابط والعلاقات الإنسانية، وتذهب روح التعاون والتراحم، وتطمس معالم السعادة والسرور، الأمر الذي يرفضه القرآن الكريم هذا الدستور الذي أوضح أنّ اختلاف الناس في أجناسهم وغرائزهم وطبائعهم وأشكالهم و ألو انهم وألسنتهم وأراضيهم إنّاما هو ليتعارفو اويتعاونو إي الاستفادة من سنن الله في الكون والانتفاع بها، وللتمكن من توظيف المسخرات الكونية التي خلقها الله - تعالى - وسخرها للإنسان، وبذلك تتحقق العمارة في كل ميادين الحياة: المادية منها والمعنوية للفرد وللمجتمع

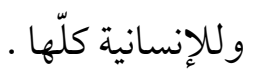

وصلّ اللهم وسلم وبارك على سيدنا محمد صلاة تبصرنا بها بأسرار كتابك، وتطيب بها عيشنا، وتهذّب به سلو كنا، وتبيض بها يوم العرض عليك وجوهنا، وتشرح بها صدورنا،

$$
\begin{aligned}
& \text { وتيسر بها أمورنا ....اللهم آمين . } \\
& \text { تحرر: في شهر ربيع الأنور • عـ أهـ = نوفمبر 1 | +r }
\end{aligned}
$$

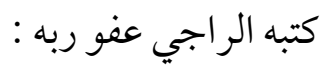

$$
\begin{aligned}
& \text { / أحمد حسين مهدي الأكرت }
\end{aligned}
$$

مدرس التفسير وعلوم القر آن بكلية الدراسات الإسلامية والعربية بنين بالقاهرة. 


\section{فهرس المسادروالمراجع}

$$
\text { - }
$$

- الإحكام في أصول الأحكام / / 10 ت / عبد الرزاق عفيفي ط : المكتب الإسلامي -

$$
\text { بيروت }
$$

- إرشاد العقل السليم إلى مزايا الكتاب الكريم لأبي السعود العمادي، ط: دار إحياء التراث

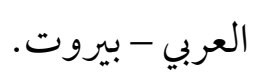

الإسلام دين الإنسانية الدكتور / محمد البهي هدية هيئة كبار العلماء بالأزهر شوال

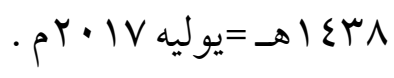

- الإسلام دين عام خالد : تحليل دقيق لمبادئ الدين الإسلامي للأستاذ / محمد فريد وجدي سلسلة بجمع البحوث الإسلامية عام 1 ا · م . - الإسلام والبناء الروحي والعقلي للإنسان للأستاذ / عبد التواب إبراهيم رضوان .

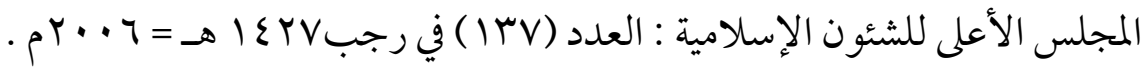
- الإسلام وضرورات الحياة لـ عبد الله قادري الأهدل . - الإنسان والقيم في التصور الإسلامي أ ـ د / محمود حمدي زقزوق ـ هدية مجلة الأزهر

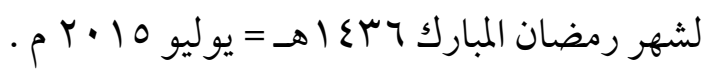
- أهمية الضمير في القرآن د / هارون يجي ترجمة ومراجعة / مصطفى الستيتي . -

- التفسير المنير في العقيدة والشريعة والمنهج، د/ وهبة بن مصطفى الزحيلي، ط: دار الفكر المعاصر - دمشق، (Y) عام ^|ع ا هـ. - التفسير الواضح د/ محمد محمود حجازي، ط: دار الجيل الجديد - بيروت، (• (1)عام rا 
- الحرية والمواطنة : التنوع والتكامل : من أعحال مؤتمر الأزهر ومجلس حكماء المسلمين عام .$\rightarrow r \cdot I V$

- الحضارة فريضة إسلامية أ ـ د / محمود حمدي زقزوق هدية هيئة كبار العلماء ضمن بجلة

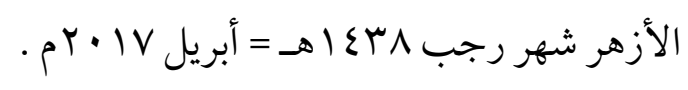

- حقوق الإنسان في الإسلام للدكتور / علي عبد الواحد وافي ط ( (r) المجلس الأعلى

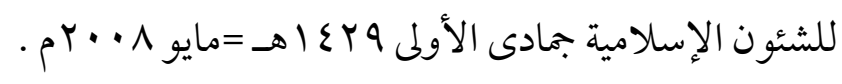

- الدستور القرآني والسنة النبوية في شئون الحياة محمد عزة دروزة ط : عيسى البابي الحلبي

$$
\text { وشر كاؤه . }
$$

- الدين والحضارة الإنسانية الدكتور / محمد البهي ـ هدية هيئة كبار العلماء بالأزهر ربيع

$$
\text { سنن ألبي داود . }
$$

سنن الله في المجتمع من خلال القر آن أ ـ د / محمد الصادق عرجون .

$$
\text { - - - }
$$

- العطاء الإسلامي للحضارة الإنسانية أ .د/ نبيل السمالوطي ط ( 1) رابطة الجامعات

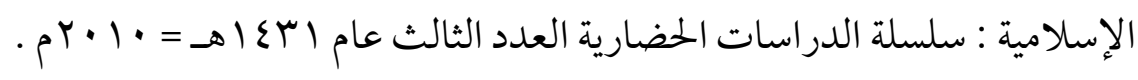
- الكليات للكفوي .

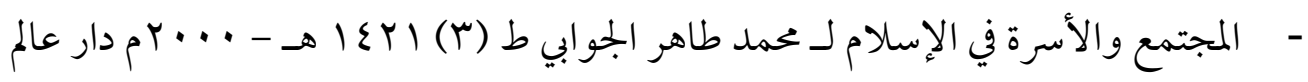

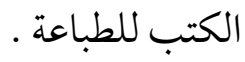




\section{5}

العدد الخامس والثلاثثون

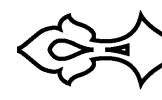

- المختار من العلاقات الدولية في الإسلام للشيخ / محمد أبو زهرة ـ سلسلة بجمع البحوث

$$
\begin{aligned}
& \text { الإسلامية عام 11 • ب م. } \\
& \text { - المصباح المنير للفيومي - }
\end{aligned}
$$

- المعجم الوسيط لمجمع اللغة العربية .

- من توجيهات الإسلام للشيخ / محمود شلتوت ط (9) دار الشروق عام • ل · بم . - المنهاج القرآني : تكوين وإقناع د/ عبد الله يوسف الشاذلي ط : المكتبة القومية الحديثة بطنطا.

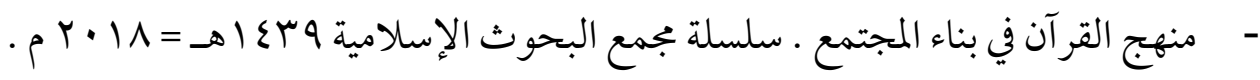
- نحو رؤية إسلامية في القانون الدولي الإنساني أ ـ د / محمد الدسوقي: المجلس الأعلى

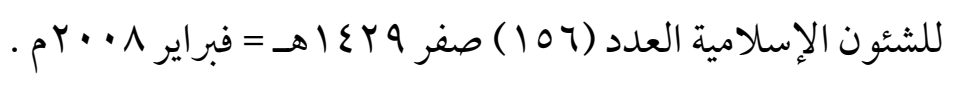

- نظرات تربوية في القرآن الكريم آ ـ د/ سعيد إسماعيل علي ط : المجلس الأعلى للشئون

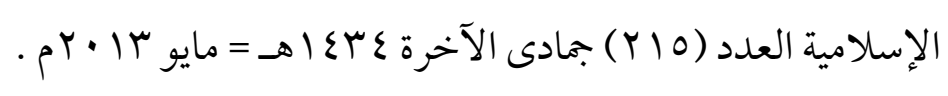

- نظرات في الإسلام د/ محمد عبد الله دراز ط : المجلس الأعلى للشئون الإسلامية العدد

$$
\text { • }
$$

- - نيل الأوطار للشوكاني ط :دار الحديث - مصر 1999 .

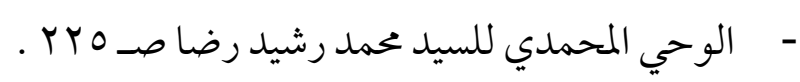




\section{فهـرس الموضوعـات}

\begin{tabular}{|c|c|c|}
\hline رقم الصفحة & 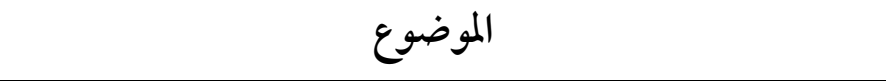 & b \\
\hline$\varepsilon \cdot I V$ & المقدمة & 1 \\
\hline 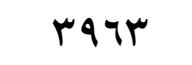 & التمهيد & r \\
\hline rq70 & الفصل الأول: بناء الشخصية الإنسانية في ضوء الآيات القرآية & $r$ \\
\hline raq7 & المبحث الأول: بناء الإنسان روحيَّا ووجدانيّا & $\varepsilon$ \\
\hline raTV & المطلب الأول: الإنسان والدين & 0 \\
\hline ravr & المطلب الثاني: الضمير الإنساني & 7 \\
\hline ravo & المطلب آلثالث: آفات البناء الروحي وكيفية علاجها في ضوء & $\checkmark$ \\
\hline rava & المبحث الثاني: بناء الإنسان فكريًّا وعقليّا & $\wedge$ \\
\hline rqva & المطلب الأول: العقل ومقاصد الشريعة الإسلامية & 9 \\
\hline rqA & المطلب الثاني: الوظيفة التربوية للعقل & $1 \cdot$ \\
\hline 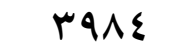 & المطلب الثالث: مبطلات التفكير السليم & 11 \\
\hline rq৯o & المبحث الثالث: بناء الإنسان جسدًا وماديًّا & Ir \\
\hline rqAo & المطلب الأول: القر آن وعنايته بالأبدان & ir \\
\hline 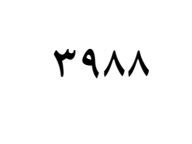 & المطلب الثاني: التدابير الوقائية في المحافظة على أعضاء الإنسان & $1 \varepsilon$ \\
\hline rq9 & الفصل الثاني: البناء المجتمعي في المنهج القرآي & 10 \\
\hline raqr & المبحث الأول: الحديث القر آني عن الأسرة & 17 \\
\hline r990 & المبحث الثاني: التضامن الاجتحاعي في البيان القرآني & IV \\
\hline
\end{tabular}




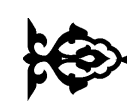

العدد الخامس والثلاثوذ

\begin{tabular}{|c|c|c|}
\hline r৭१V & المبحث الثالث: المواطنة والعمل المشترك & $1 \wedge$ \\
\hline ४৭११ & طريق العلاقات الدالث: التوجيهات القر آنية في بناء الإنسان عالمياً عن & 19 \\
\hline$\varepsilon \cdots$ & المبحث الأول: القرآن الكريم وترسيخ القيم الحضارية & $r$. \\
\hline$\varepsilon \cdots$ & المبحث الثاني: القرآن الكريم وتوثيق العلاقات الدولية والتعايش & Yl \\
\hline$\varepsilon \cdots$ & المطلب الأول: قواعد العلاقات الدولية في الشريعة الإسلامية & rY \\
\hline$\varepsilon \cdots q$ & المطلب الثاني: القرآن والتعايش السلمي بين بني الإنسان & r \\
\hline$\varepsilon \cdot 1$. & من أهم الأمور التي تساعد على تفعيل دور التعايش السلمي & Y $\varepsilon$ \\
\hline$\varepsilon \cdot 1 r$ & 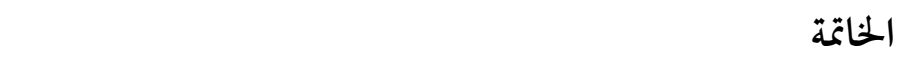 & ro \\
\hline$\varepsilon \cdot 1 \varepsilon$ & فهرس المصادر والمراجع & ry \\
\hline$\varepsilon \cdot I V$ & فهرس الموضوعات & YV \\
\hline
\end{tabular}

